اتجاهات طالبات كلية التربية بجامعة الملك سعود نحو أساليب التقويم

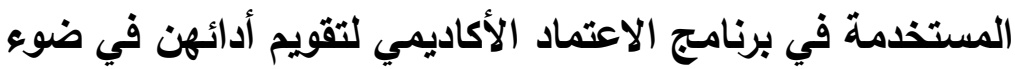
التخصص والمستوى والمعدل الاراسي

د. عفاف سالم المحمدي

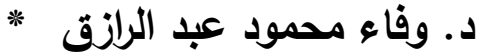

* د. دوداد عبدالرحمن أباحسين

المقدمة والخلفية النظرية

تعتبر مخرجـات التعلم ونـواتج أداء المتعلمـين هـي محسور العمليـة

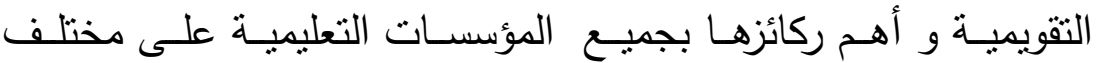
مستوياتها (David et al.,2010).، ونظرا لأن التقويم التربوي يلعب دورا أساسيا في توجيه العملية التدريسية وإثراء تعلم الطلاب وتحسين مخرجات العملية التعليمية (نصار ، • ( • ب)، فإن الاتجاهات ولهاء الحديثة للتقويم تعطي اهمية كبيرة لمشاركة الطالب برأيه وفكره في وضع السياسات التعليمية والتقويميـة وهي السياسـات التي تتعلق بالأنظمـة والطرائق التقويمية بما

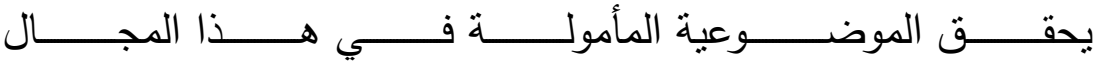
(Ketterlin-Geller et al.,2009) (وبصفة خاصـة على مسنوى التعليم الجامعي وذلك بهدف تحقيق موضوعية قياس نواتج العملية التعليمية بما يحقق الاهداف المنشودة منها وبما يلبي احتياجات المتعلمين واحتياجات

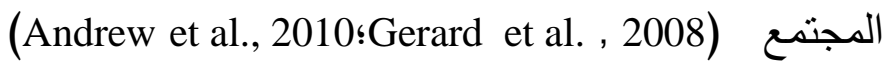

"ذُعم هذا المشروع البحثي من قبل مركز بحوث الاراسات الإنسانية، عمادة البحث العلمي ، جامعة الملك سعود.

" أستاذ علم النفس التريوي المساعد - كلية التربية - جامعة الملك سعود - المملكة العربية السعودية

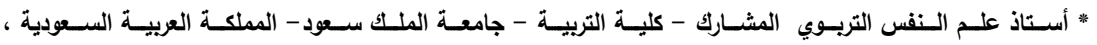

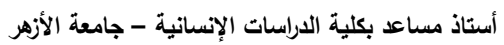
* أستاذ التربية الخاصة المساعد - كلية التربية - جامعة الملك سعود- الملكة العربية السعودية 
وتمثل الاختبارات التحصيلية التقويمية إحدى الوسائل المهمة والبارزة

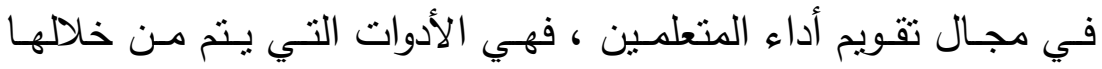

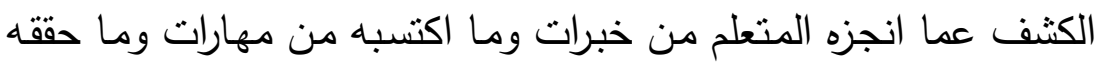

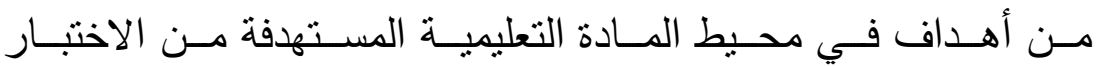
(Hurwitz et al., 2007; Meisinger et al., 2009)

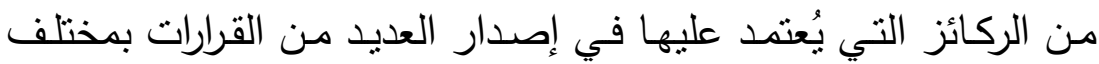
$\ddot{2}$

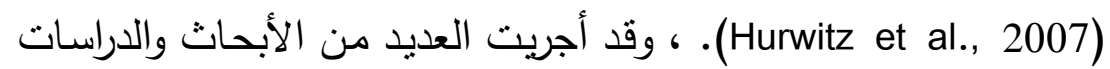

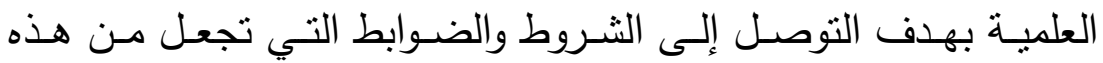

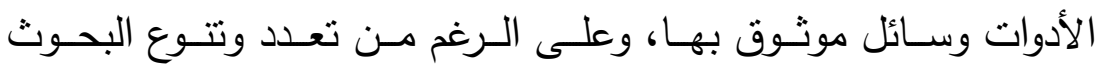

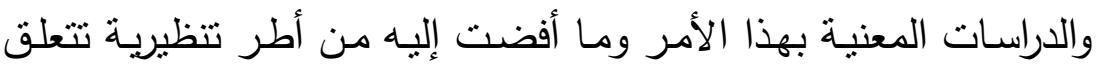
بطرق وشروط وضوابط الإجراءات الخاصة بإعداد الاختبارات التحصيلية

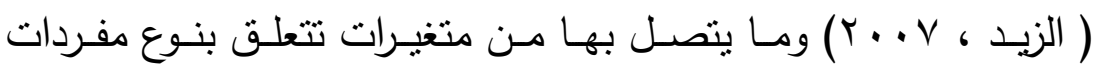
$\ddot{a}$

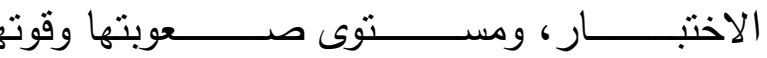
والمستويات المعرفيـة المستهدف (Tasdemir \& Mehmet 2010) قياسـها. (2009, يcuk \&Walters) ومدى تمثيـل الاختبـار للنطـاق

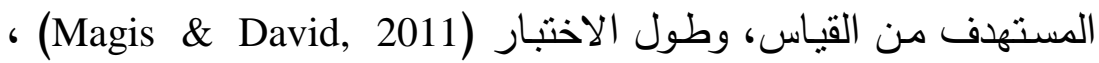

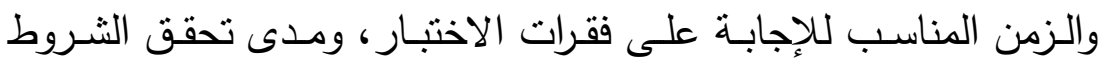
السيكومترية للقياس (ياسين ، ع . . †) (Tavakol et al., 2011)، وتوزيع

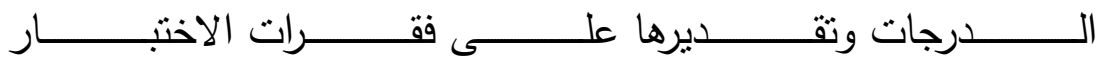
وإعـداد جـدول المواصـفات (De la Torre et al.,2011) (Aaron et al.,2005) هذه اللحظة من بعض نواحي الضعف وأوجه القصور التي نتكل عوائق

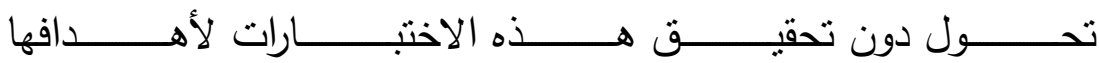
(Champlain, 2010) 
كما تمثل أيضا الأنشطة التعليمية التي يكلف بها المتعلم وسيلة أخرى

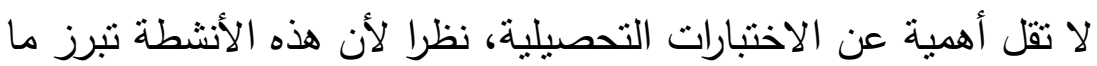

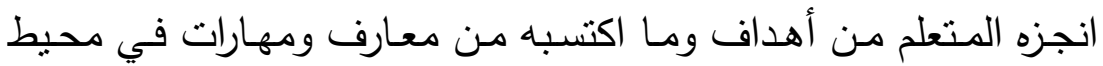
المادة والخبرة المتعلمة (2010, Christopher \& Don) ، حيث ينظر لمنل الأنشطة على أنها أساليب تنتخدم في تقويم الأداء الحقيقي للمتعلم

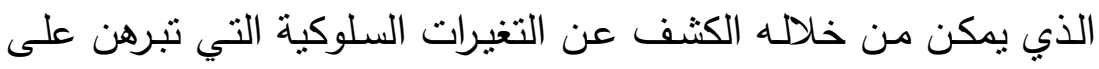

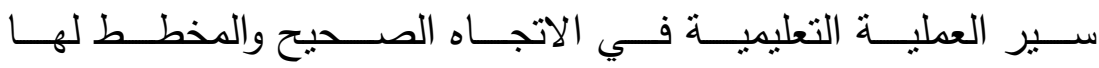
(Hughes, 2011) ، وتتتوع هذه الأنشطة التعليميـة في ضـوء طبيعـة النشاط التعليمي وما يرتبط بـه من أهداف تعليمية ووجدانية أو حركية، ولنه ومن بين هذه الأنشطة :الأنشطة الفردية وهي الأنشطة التعليمية التي ينجزها المتعلم بمفرده ودون معاونه من

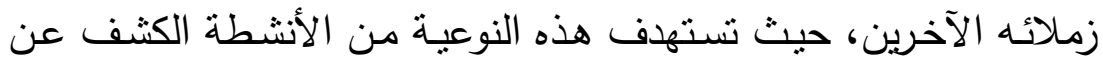
أوجهـ القوة والضعف في أداء الطالب وتحديد المعوقات التي يمكن ان تحول دون إنجازه للأهداف التعليمية، حيث يمكن الإفادة من هذه النوعية

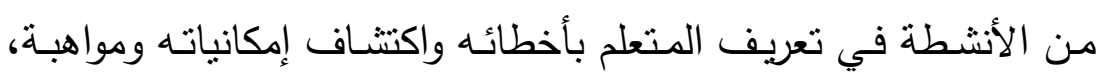

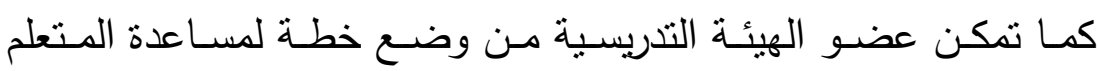
والتخلص مـن نقاط الضـف لايـهـ وتحقيـق الأهـاف التـي لـم يسـنطع (Jacqueline et al, 2010) إنجازها.

\section{الأنثطة الجمعية}

وهي الأنشطة التي تكلف بها مجموعة من المتعلمين وتتلخص هذه

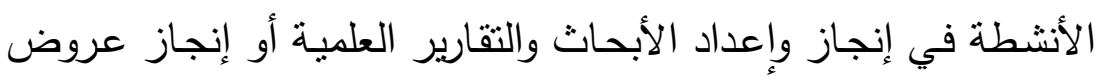

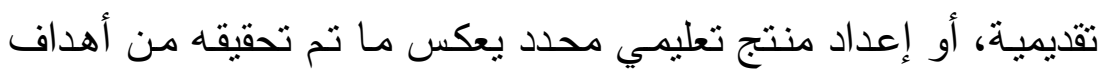
ترتبط بهذا اللون من النشاط ، وتنتهدف هذه النوعية من الأنشطة تتمية

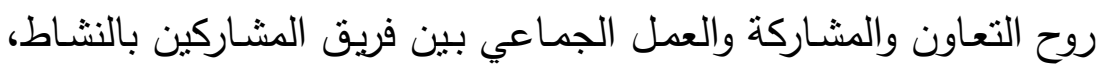


كما أنها تسـاهم في إتمام وإنجاز العمل بصـورة تحقق تكامل الخبرات

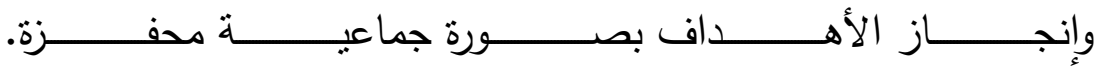

( Chung \& Behan, 2010)

\section{طرق التقويم}

يحقق التقويم العديد من الأهداف التي تسعى إليها المؤسسة التعليمية

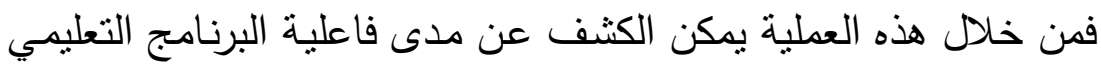

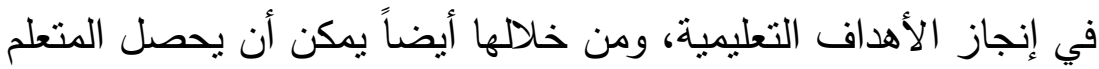
وكذلك المعلم أيضاً على أنواع من التغذية الراجعة التي تفيد كلا الطرفين في تصويب مساره التعليمي في الاتجاه المفضل، كما انها تساعد في لهي الكثف عن نواحي القوة والضعف التي يمكن ان تواجه العملية التعليمية

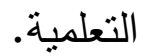

ولكي يحقق التقويم الأهداف الذي يسـى إليها فإن القائمين على

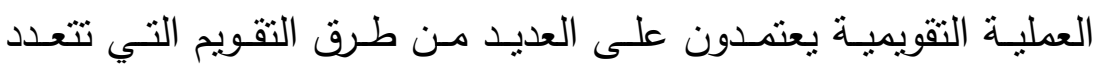

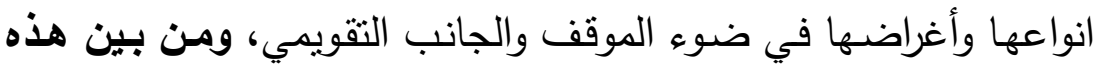

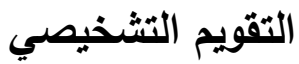

وهو شكل من أشكال التقويم يستخدم مـع المتعلم غير القادر على

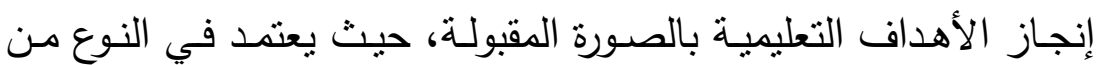
اثـكال التقويم اختبـارات ووسـائل تشخيصـية للكثـف عـن المشـكلات والمعوقات التي تحول دون إنجاز هذا المتعلم للأهداف للعمل على حلها ( Scherz et.al,2011)

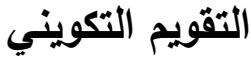

هو شكل من أشكال التقويم ويستخدم أثناء تتفيذ البرنامج التعليمي بهذف الحصول على التغذية الراجعة لكل من المتعلم والمعلم على حد سواء، وبالتالي تعديل مسار المتعلم وكذللك العملية التعليمية في الاتجاه 
الصحيح.ويساعد هذا النوع من النقويم في بناء الخبرة التعليميـة للمتعلم

على اسس سليمة (Michelle,2010). التقويم الختامي

ويستخدم هذا النوع مـن التقويم في التعرف على فاعليـة البرنـامج التعليمي والتعرف على ما تحقق من أهداف مرتبطة بهذا البرنامج ومالم

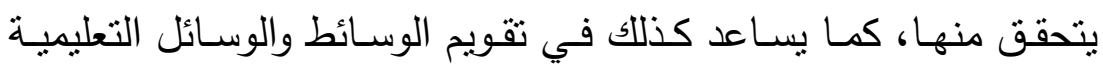
وكذللك المناهج بهدف تعديلها أو تطويرها كما يساعد في نقل المتعلم من لن مجـال دراسـي لآخـر أو مسـتوى دراسـي لمسـتوى آخـر، وكـذلك مـنح

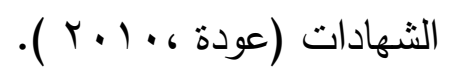

وبالرغم من أن القائمون على العملية التقويمية لديهم خبرات متعددة

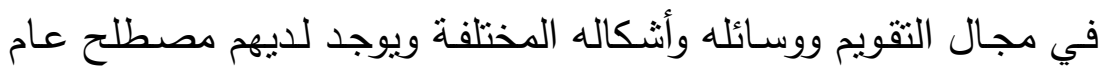
عن التقويم، فإن تباين واختلاف فهم هذا المصطلح فيما بينهم يتوقف

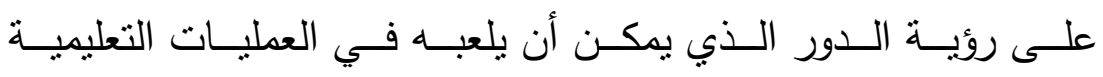

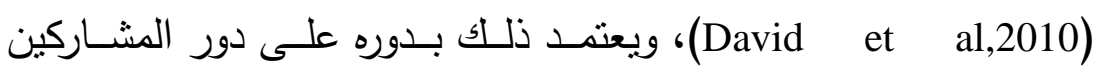
( مقوِمين ومقوَمين ) في التعليم وعمليات التقويم المختلفة، وهذا التباين

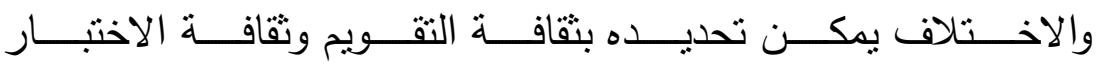
(Birenbaum, 2000)، و تؤثر تباين هذه الثقافات في تبني القائم على لئ العملية التقويمية لطرق وأساليب وإجراءات تقويمية تشكل نموذجا تقويميا

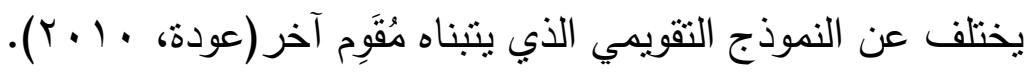

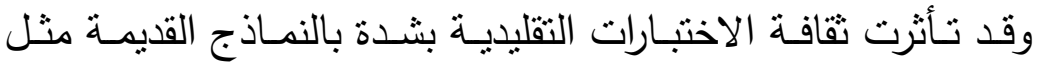
نمـوذج المدرسـة الســوكية للـتعلم حيـث كـان الاعتقـاد فـي الاختبـار الموضوعي المقنن (Shepard, 2000)، وأن المواقف الاختبارية ينبغي أن تتفصل عن عملية التعليم، ونتيجة لحدوث تطورات في المجتمع تغير

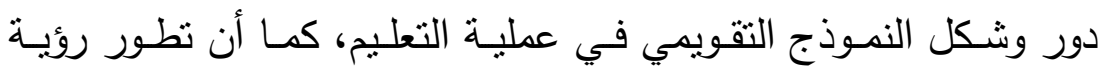

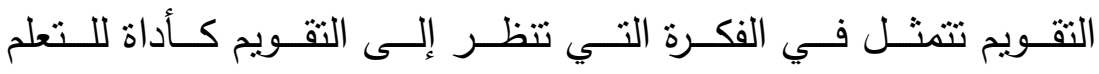


(Baeten et al,2008) تتظر إليه كوسيلة لتقدير الدرجات، وبالتالي فإن الثقافة الجديدة للتقويم

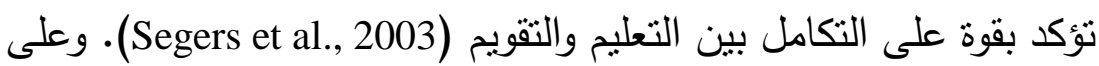
الرغم من ذلك فإن التكامل بين التعليم والتعلم وعمليات التقويم مازال هو التحدي الأكبر لاى كثير من المعلمين(Struyf et al,2001) ، فلقد أنثار (Glasner ,1999)

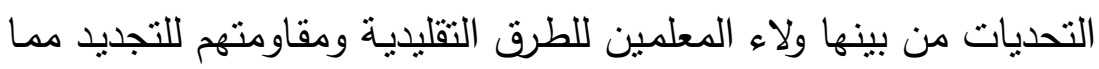
يتسبب في انتشـار الاختبارات التقليديـة وتبني النموذج التقويمي القديم

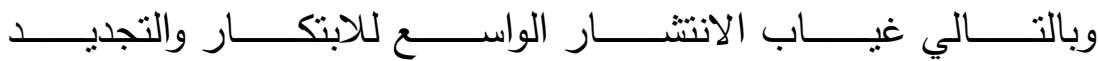
.(Kuhlemeier et al , 2004)

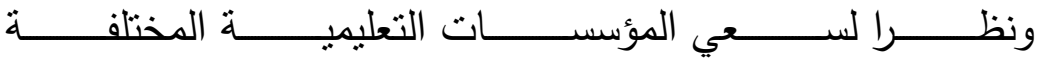
(ومن بينها كلية التربية بجامعة الملك سعود) في الوصسول إلى أعلى مستويات الجودة وتقديم خدمات وبرامج تعليمية وتقويمية لتحقيق التميز والريادة بين المؤسسات التعليمية الممانلة، فإن هذه الدراسة تحاول إلقاء الضـوء على البرنـامج التقويمي المسـتخدم في تقويم أداء طـلاب كليـة فئة التربيـة بجامعـة الملكلك سـود للتعـرف على مـدى فعاليـة هـذا البرنـامج

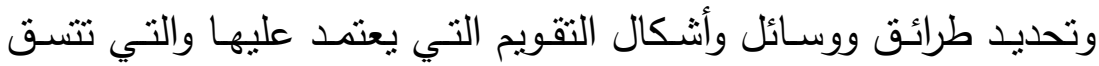

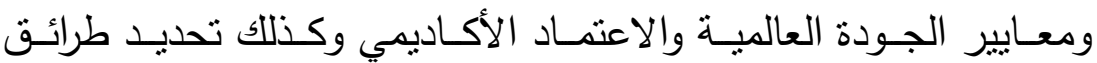
ووسائل التقويم التي لا تتسق وتلك المعايير وذللك من خلال وجهة نظر

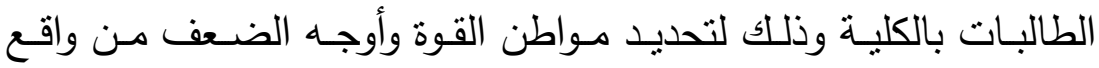
الممارسـات التقويميـة التي تجري على أرض الواقع بهدف تقديم منتج

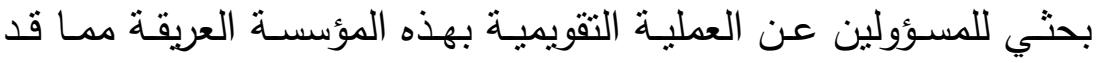
يساعد في تطوير الواقع التقويمي بها بما يلبي الأهداف التي تسعى إليها هذه المؤسسة في تحقيق مزيدا من الجودة ومزيدا من الريادة والتميز . 
اتجاهات الطلاب نحو التقويم

لقـد أجربـت بعض الدراسـات لاستقصـاء الأثر الــي يحدثـه إدراك

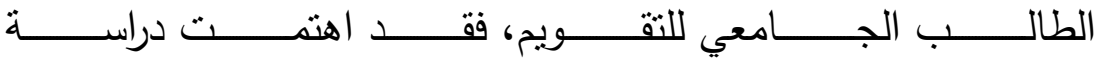
(1994, Scouller \& Prosser)، بـالتعرف على إدراك المتعلم لأسـئلة اختبارات الاختيار من متعدد وكذللك التعرف على إدراكهم العام تجاه ما لا لـا

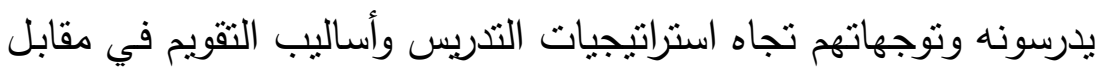

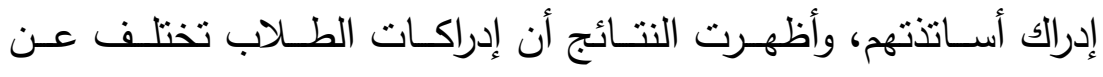

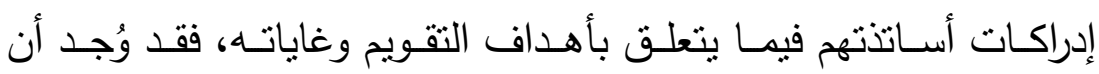
الطلاب لهم إدراك خاطئ لمفهوم الفهم، حيث لا يتمايز لديهم عن مفهوم

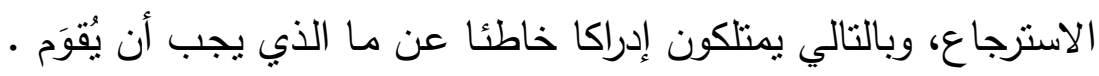
أما دراسة (Scouller,1998) ذكرت أن هنالك ارتباطات بين تفضيلات

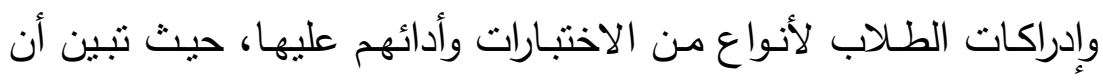
الأفراد المفضلون لاختبارات أسئلة الاختيار من متعدد يدركون أن هذه الآن

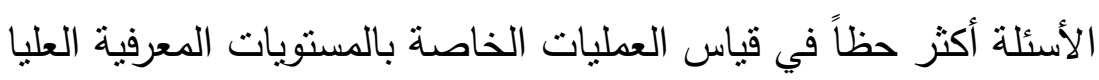

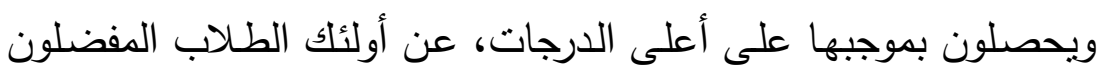

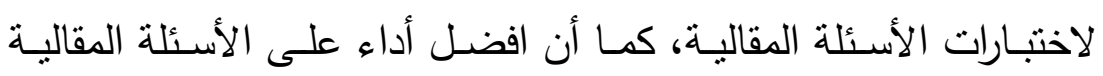

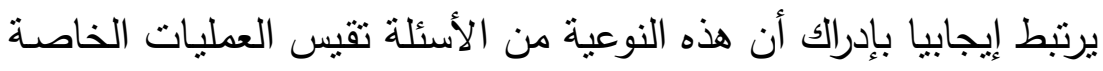

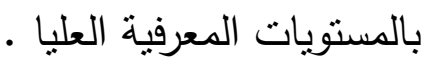
ويبدو أن إدراك الطلاب لأنواع معينة من الأسئلة قد يرتبط بأدائهر عليها، فلقد أثشارت دراسة (Baeten et al., 2008) أنه لا توجد ارتباطات بين إدراكات طلاب الجامعة لأسئلة الاختيار من متعدد ودرجاتهم عليها

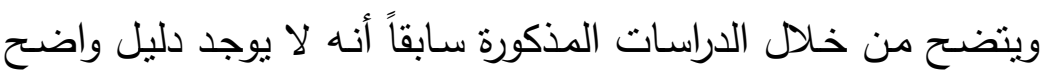
على أن مدركات الطلاب لوسائل النقويم المستخدمة هي تلك المدركات

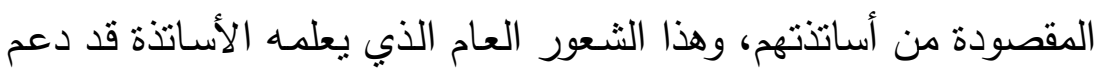
بنتائج دراسة (MacLellan,2011) والتي أظهرت أن هناك فروق جوهن وهرية 
بين الطلاب وأسـاتذتهم في المدركات الخاصـة بـأغراض التقويم وأهدافهـ والعمليات المعرفية المستهدف قياسها بعمليات التقويم.

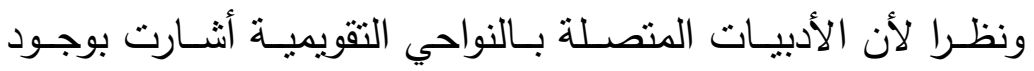

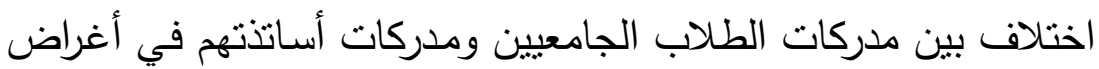
وأهداف التقويم كان من الضروري الوقوف على آراء الطلاب الجامعيين

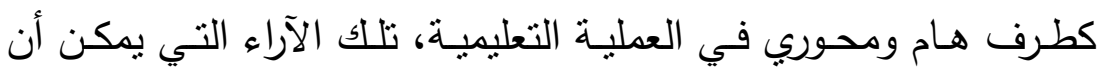

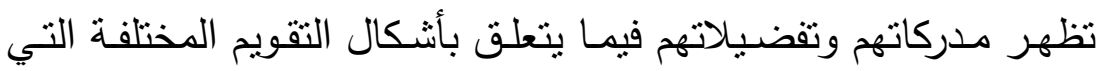

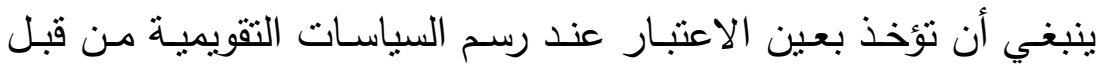

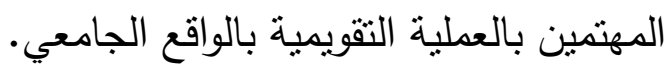
تفضيلات الطلاب لأشكال معينة من التقويم

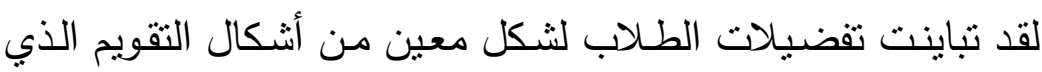

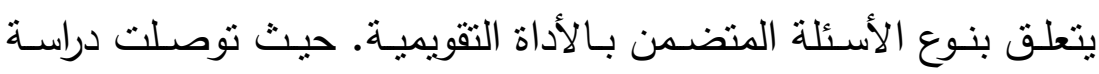
(wheeler \& Berkowitz,1993)

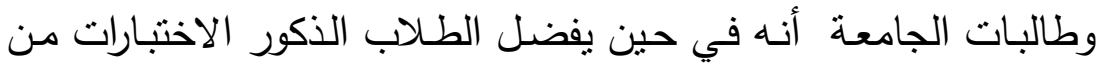
نوع الاختيار من متعدد فإن الطالبات يفضلن الاختبارات المقالية، كما ليا لهابل أنشارت الدراسـة إلى أن تفضيل كل من الطـلاب والطالبات الاختبـارات

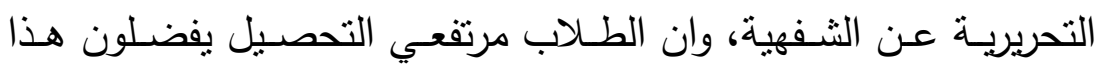

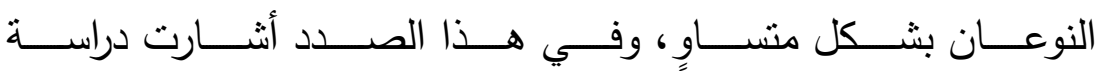
(Ben-Chaim \& Zoller ,1997) الاختبارات التحريريـة، وكذللك الاختبـارات غير المحدودة بوقت وكذللك الاختبارات التي تعتمد على الفهم وليس على مجرد التذكر، كما أن أسئلة

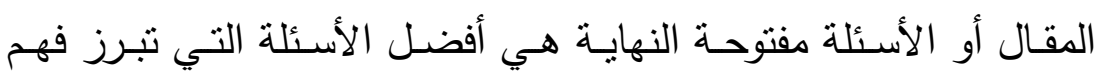
الحقائق، كما توصلت دراسـة (1998, Birenbaum \& Feldman) إلى أن هلن الطلاب مرتفعي التحصيل يفضلون أنواع الأسئلة المقالية، بينما الطلاب الطلاب منخفضي التحصيل يفضلون أنواع أسئلة الاختيار من متعدد، 
وقد أظهرت الدراسة عدم وجود اختلاف بين تفضيلات الطلاب مرتفعي ومنخفضي التحصيل لنوعي الاختبار الثفهي والتحربري، كمـا اشـارت

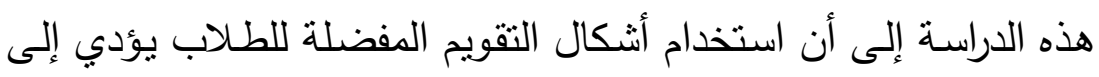

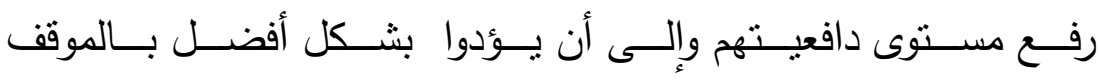

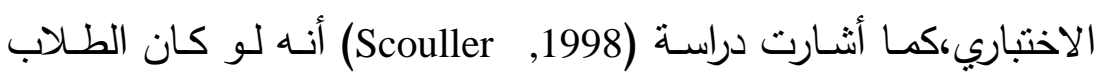
يفضلون أسئلة المقال يمكن أن يكونوا أكثر حظا للحصول على مخرجات

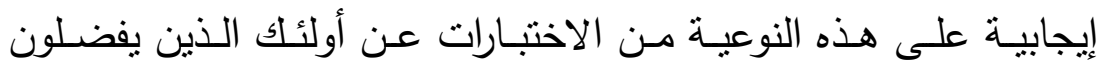

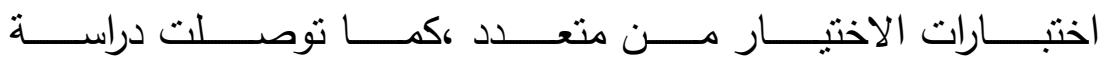
(Birenbaum\& Feldman ,1998) إلى أن طلاب الجامعة يفضلون أسئلة الاختبار من متعدد، وكذلك أسئلة المقال البسيطة عن الأسئلة المقالية

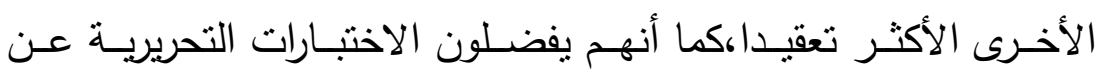

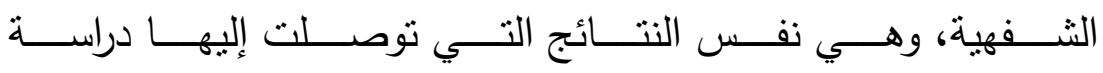

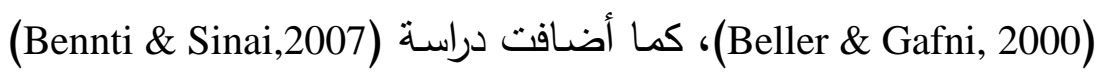
أن درجات الطـلاب على أسـئلة الاختيار من متعدد أعلى من درجات

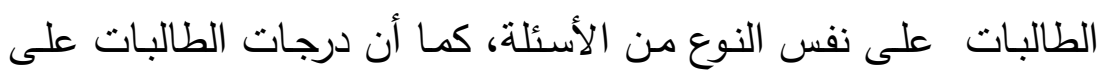

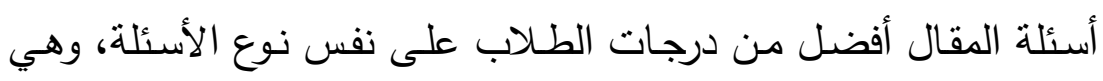

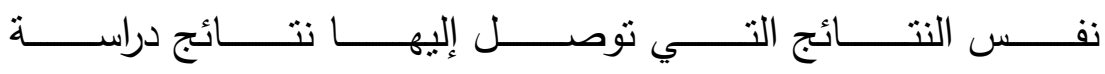
(Gellman \& Berkowitz, 2008)

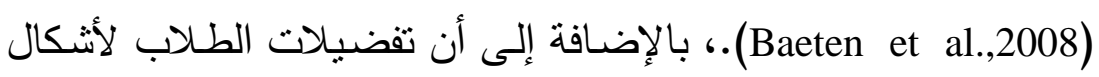

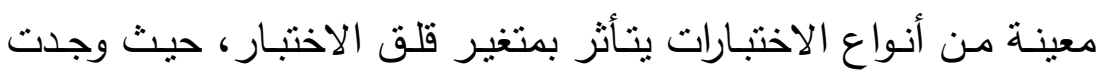

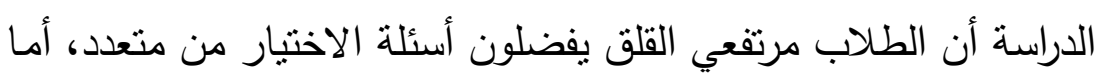

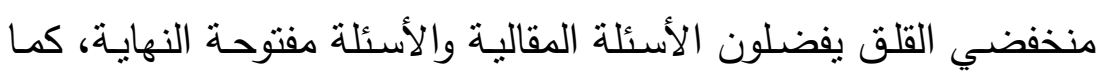
أنشارت دراسات (Traub \& McRury, 2010) إلى أن طلاب الجامعة لديهر ميل إلى أسئلة الاختيار من متعدد وأسئلة المقال البسيطة عن الت طن 
الأسئلة المقالية الأخرى المعقدة كما أنهم يفضلون الاختبارات التحريرية عن الثفهية.

تبين مما سبق أن تفضيلات الطلاب لأنواع معينة من أشكال التقويم

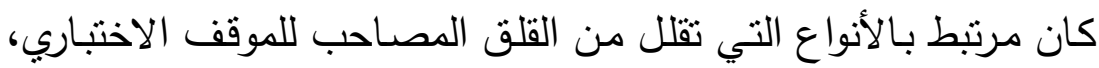
وقد تبين أن الطلاب وكذلك الطالبات الذين يتلقون أشكال يفضلونونها من من فئن التقويم يؤدون في المواقف الاختباريـة بشكل أفضل مما يوحي بضـرورة مشاركة الطلاب والطالبات بآرائهم القائمين على العملية التقويميـة عند بند وضع أو اقتراح نظام تقويمي يمكن أن يؤدي في النهاية إلى أداء أفضل من جانب المتعلمين وهذا ما تسعى إليه الدراسة الحالية.

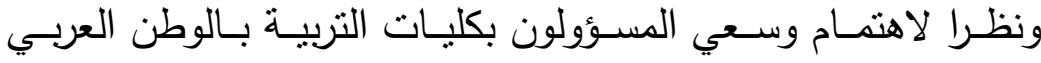

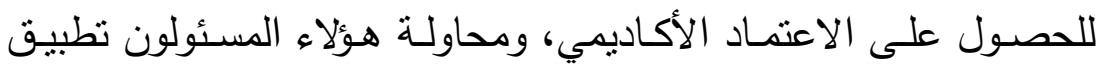
نظم التقويم التي تتفق مع معايير الجودة العالمية وهي معايير المجلس وله

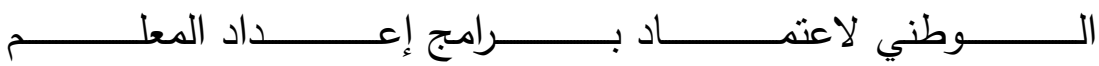
،(National Council for Accreditation of Teacher Education NCATE) والتي تتعلق بعناصر الإطار المفاهيمي المحدد من قبل الكلية، كان من الضـروري الكثـف عن رؤى كل مـن الطالب وعضـو الهيئة التدريسية التي تبرز مدركاتهم نحو أثنكال التقويم المختلفة وكذلك الكثف عن من مدى

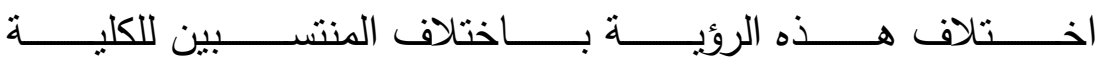
( طلاب - أعضاء هيئة تدريس). ونظرا لأن الأدوار التي يقوم بها الطالب الجامعي - حديثا- بالبرامج

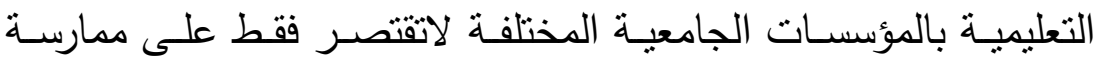
للأنشطة التعليمية أو مجرد التحصيل الدراسي ، ولكنها تتجاوز ذلك إلى بلى

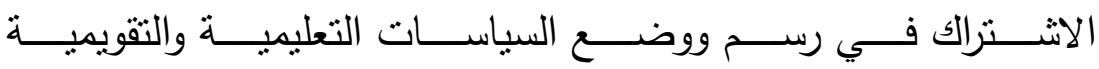

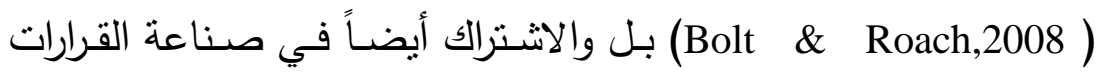
المتعلقـة بتلك السياسـات (Ketterlin-Geller et.al.,2009)، فقد رأت 
الباحثات ضـرورة وضـع الرؤيـة التقويميـة للطالبـات الجامعيات للبرنـامج

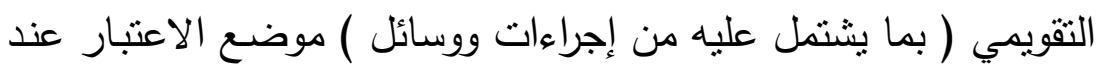
اعداد الادوات التقويمية اللازمة لتقويم أدائهن تقويم موضوعي متفق إنقاء عليه

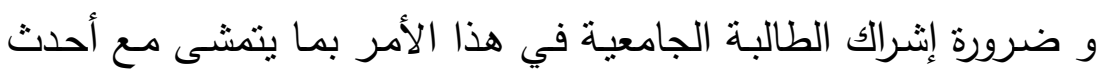
الأدوار التي يقوم بها الطالب الجامعي والتي ترمي إلى الاشتراك في رسم

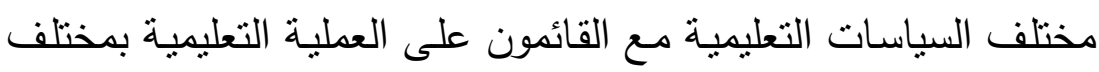
المؤسسات العلمية والأكاديمية.

ونظـرا لأن الموضـوعية والثــول في تقويم أداء الطالب الجـامعي

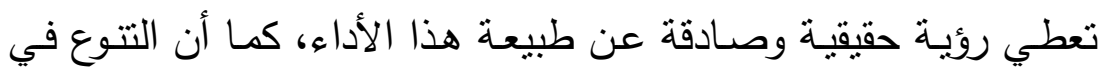
أساليب ووسائل التقويم يعطي رؤية متكاملة عن طبيعة هذا الأداء، فقد اهتمت الدراسة الحالية في إيراز الجوانب التي يجب استهدافها تقويميا في أداء الطالبة وكذلك الوسائل والإجراءات المناسبة لتقويم هذا الأداء، وقد لهد تبين للباحثات ضرورة الكثف عن عمليات وإجراءات ووسائل التقويم في هي

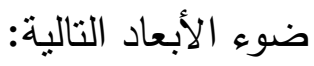
أبعاد التقويم 1- طبيعية و مواصفات أدوات التقويم. r- مراحلـل التهـويم (تمهيـدي- تكـويني (بنـائي ) - تشخيصـيحقيقي - ختامي )

r- - جوانـب ومجـالات التقـويم (الحضــور - إلتـزام خلقي ـانشـطة (فردية وجماعية)- الخبرات - المهارات)

ع - التهيئة للتقويم (الوقت السـابق على التقويم - التهيئة النفسية للطالب ومنحه الفرصة للاستعداد) 0- نظم الامتحانات و المراقبات (توزيع الامتحانات زمنيا على أيام

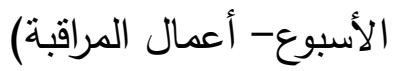


צ- التصحيح و التقييم (توزيع الدرجات-تحديد الأوزان النسبية وفقا للأهداف (المدة القانونية التصحيح - نماذج الإجابة - تدقيق

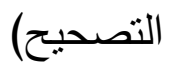
وفيما يلي بيان هذه الأبعاد

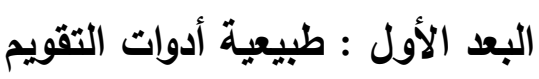

ويتضـمن مقترحات تتعلق بطبيعـة أدوات التقويم بأثـكالها المختلفـة أبرزتها الدراسـات التي تتاولت أنثـكال أدوات التقويم مـن خـلد رؤيسة الطالب والمعلم ومن بينها دراسة (Gerard et.al., 2008) التي أوضحت

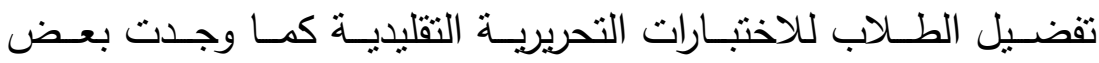
العلاقات بين تفضيلاتهم لأنواع معينة من الاختبارات ودرجاتهم عليها،

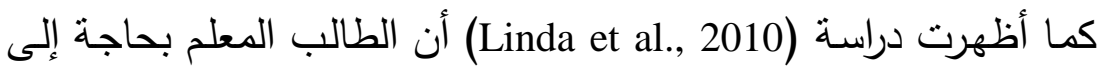
وسـائل تقويم منتوعـة للتعـرف على تأثثر بـرامج التربيـة على المعرفـة

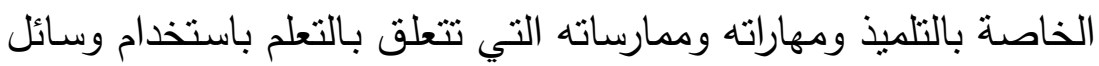
قياس متعددة ومتتوعة يمكن من خلالها تطوير هذه البرامج واستمرار تحسينها، كما أظهرت دراسة (Hicks et al. 2010) أن الاختبارات (المقاليـة) والتـي تهتم بـالنواحي التطبيقيـة والتـي يكون بمقدورها إبـراز النواحي الابتكارية هي أفضل الاختبارات التي تستخدم في الكثف عن بن

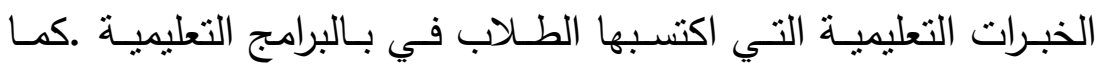
أنشارت دراسـة (James, 2011) إلى أن الاختبارات الثفهية هي وسيلة التقويم الحقيقي في الكثف عن مهارات التفكير الناقد وكذللك مهارات

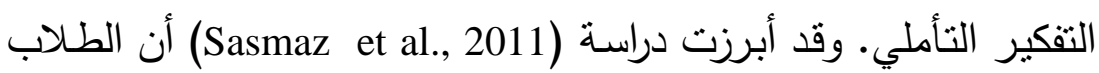
المعلمون راغبون باستخدام الاختبـارات الحاسوبية والاختبـارات الثـفهية

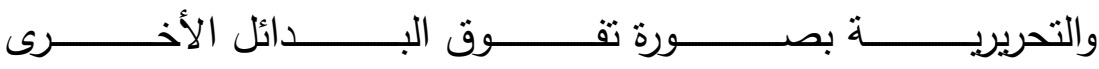
المختلفة في مستقبلهم المهني ، حيث يعتقدون أن الاختبارات المحوسبة 
أكثر دقة وأكثر موضوعية وسرعة في تقدير الدرجات كما أنها لا تتأثر بالذانية. وقد تبين أن اغلب أدوات التقويم الواردة بالأدبيات السـابقة كانت: الاختبارات التحريرية ومنها المقالية، و الموضوعية، الاختبارات الثفهية، البوتوفوليو، الاختبارات الحاسوبية، مصفوفات التقدير اللفظي، البحوث، التقارير ، الواجبات المنزلية، التقويم الذاتي للطالب، تقويم النظراء وهذه الأدوات سوف تدرج كأدوات مقترحة بالمقياس التي سوف تعتمد عليه الدراسة الحالية.

\section{البعد الثاني: مراحل التقويم}

ويتضمن هذا البعد مقترحات خاصة بمراحل التقويم ظهرت من خلال

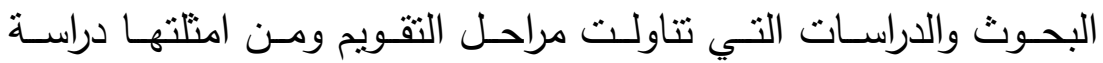

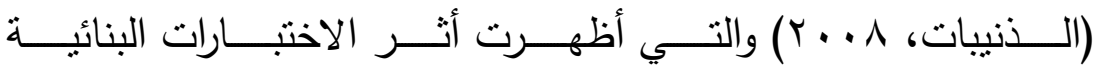
(وهي الاختبارات المستخدم في عمليات التقويم التكويني) الواضـح في التي تحسين التحصيل الدراسي للطلاب، كما أن التقويم المستمر والاختبارات المتكررة تحفز الطلاب على التركيز والمتابعة المستمرة لكل مايقدم لهم

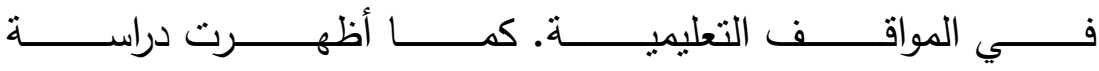
(Ozogul \& Sullivan. ,2009) توجهات الطلاب نحو استخدام أساتذتهر لبعض أسـاليب التقويم مثنل مصفوفة التقدير اللفظي Rubric، وأيضـا

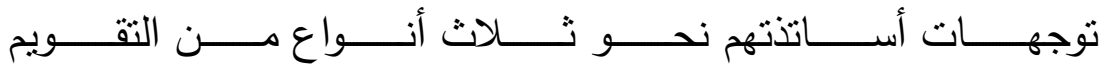
( تقويم المعلم ، تقويم النظراء ، التقويم الذاتي)، وقد أثنارت النتائج إلى نى

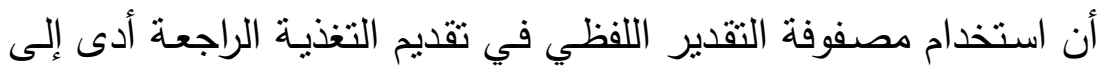

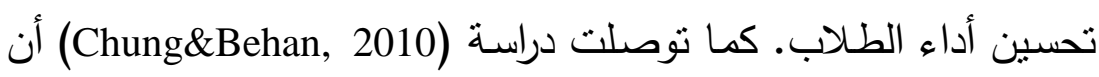
التقويم الحقيقي على أساس النشاط التعليمي الجماعي يحسن تعلم طلاب لنس

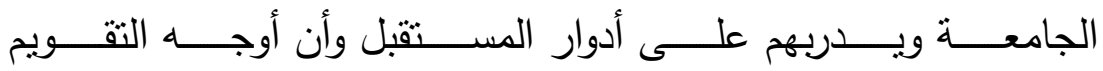
الحقيقي مثل الكتابة الورقية التحريرية، عرض الملصقات الورقية كنتاج 
عمل جماعي ، والعروض الثفهية، وكذللك الأنشطة الفردية التي تتمثل

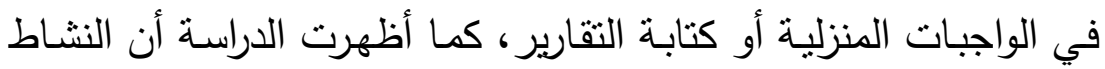

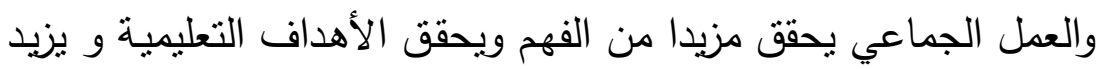

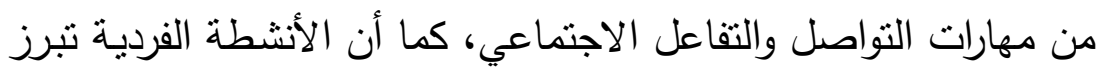

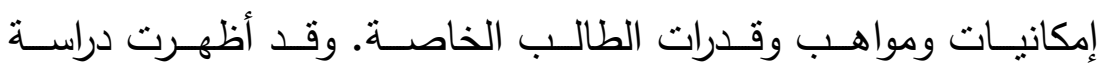
(Jacqueline et al., 2010 ) في التقويم كما أن الاختبار واسع النطاق يؤدي إلى تقديم معلومات حول تعلم التلاميذ، كما يفيد في إعداد الاختبارات التي تقيس مهارات التفكير وتعلـم المفـاهيم كمـا يشـجع التلاميذ على التأملـ في استجاباتهم، كمـا أنثـارت دراســة (Michelle,2010) التـي اسـتهدفت الكثـــ عـن فعاليـة

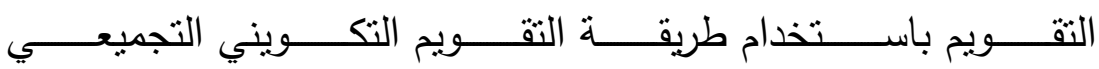
وهي طريقة في التقويم (Formative Summative Assessment FSA) تدمج كل من الطريقتين التقويم التكويني، التقويمي والتجميعي معا في طريقة واحدة وهي طريقة حديثة صاغها ويننجر (Wininger 2005) في الاحتفاظ بالمفاهيم، وقد توصلت الدراسـة أن طريقة الدمج بين التقويم التكويني والتجميعي والتي يستخدم بها الاختبار النهائي كوسيلة يمكن من خلالها أن يتعرف الطالب على أخطاؤه ، أدت إلى تحسين قدرة الاحتفاظ

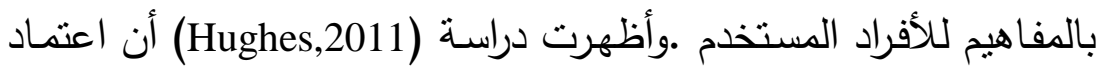

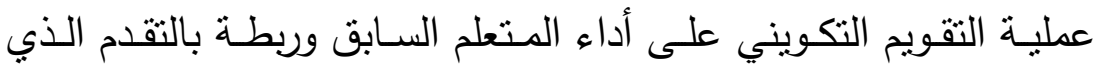
يمكن أن يتحقق على المدى البعيد قد يكون له نأثيرات أكثر دافعية لدى لـ له

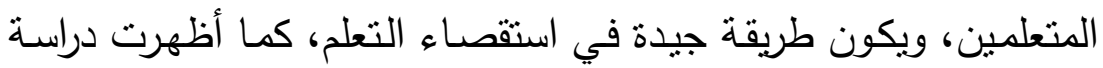

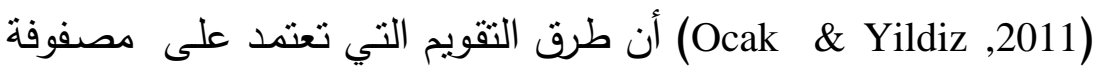

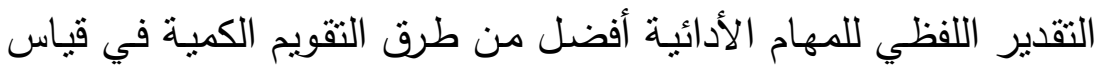

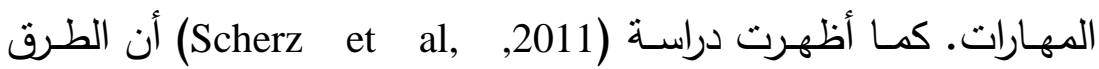
التشخيصية تزود المعلم بـليل على نجـاح الطالب في إنجاز المهام 
والممارسات التعليمية الخاصة بموضوعات المقرر، كما أن طريقة التقويم

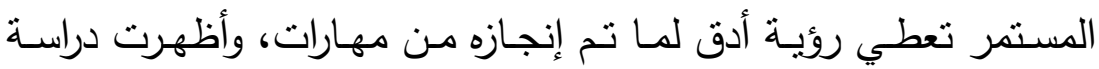
(Tang\& Harrison,2011) الخاصـة بـه في عمليات التخذيـة الراجعة، وذللك من خـلال فحص ثناث طرق للنغذية الراجعة وهي الطريقة العاملية التقليدية المستقلة ، والطريقة المتمركزة حول الطالب والطريقة المحلية التقليدية وقد أظهرت النتائج أن الطريقة المتمركزة حول الطالب هي الطريقة الأفضل في تقديم التخذيـة

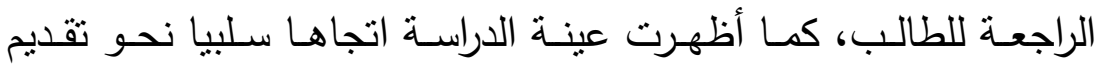
التغذية الراجعة في صورة مجرد درجات.

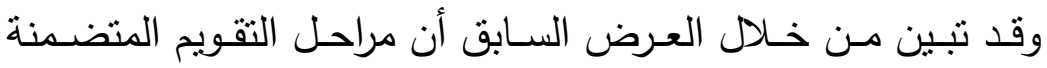
بالأدبيات التي اهتمت بمراحل التقويم هي: تقويم تمهيدي ، تقويم تكويني

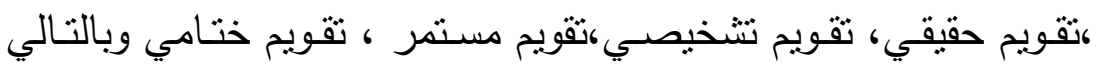
سوف تدرج هذه المراحل في المقترحات الخاصـة بنظم وطرق ومراحل لئل التقويم بالمقياس الذي سوف يجرى استخدامه بالدراسة الحالية. البعد الثالث: جوانب ومجالات التقويم يتضمن هذا البعد مقترحات خاصة بجوانب الأداء المستهدفة تقويميا

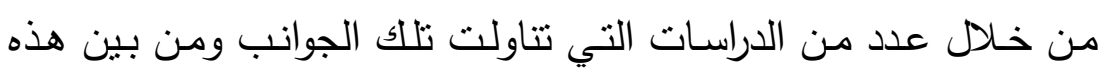
الدراسـات دراسـة (Christopher \& Don,2010) التي استهدفت التعرف على جوانـب التقويم التي ينبغـي أن تسـتهدف مـن العمليـة التقويميـة

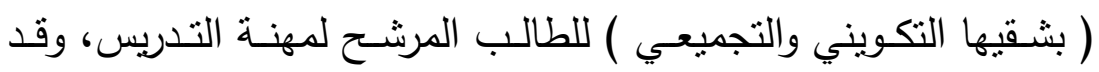

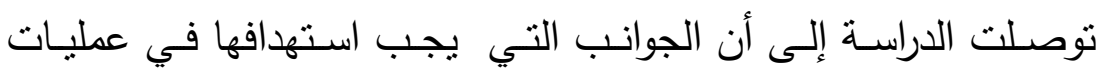

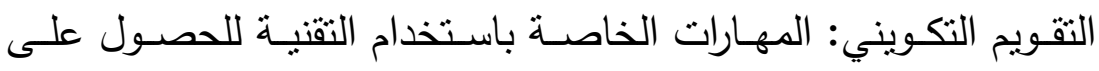

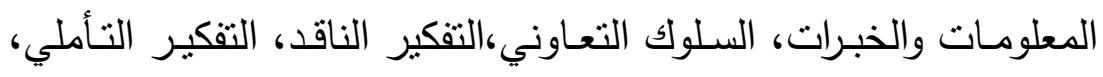
مهارات البحث، مهارات الاتصـال، ويمتد ليشمل أيضـا الجوانب الخلقية

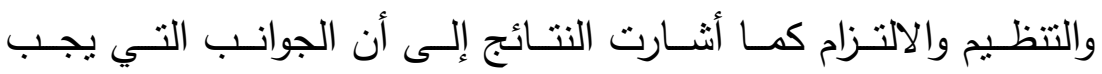


استهدافها في التقويم التجميعي وهي: المسـتويات العليـا مـن المعرفـة،

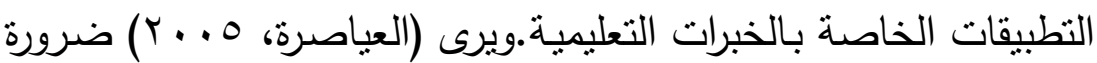
تنويع الأسئلة التقويمية كي تستهدف المجالات التقويمية الثناث :المعرفية

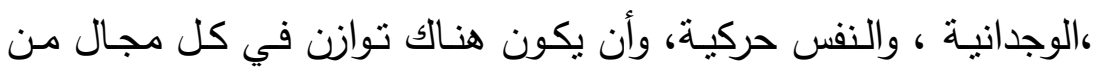

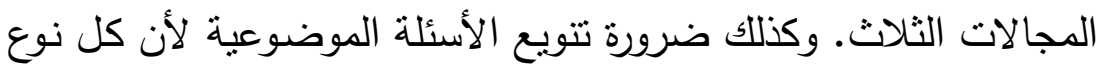
منها يحقق أهداف من مجالات مختلفة قد لا يحققها غيره بنفس الدرجة الاته

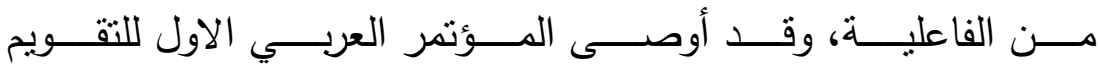

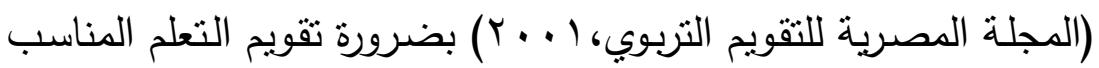
في ضوء اهداف التعلم الكلية، وأن يكون التقويم شاملا جميع جوانب نمو التهوبه

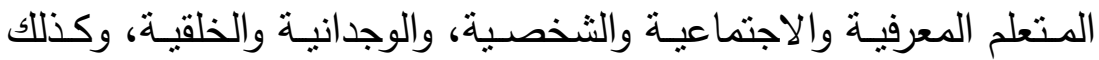
ضرورة تتوع أدوات التقويم التي تنتخدم في تقويم الطالب.

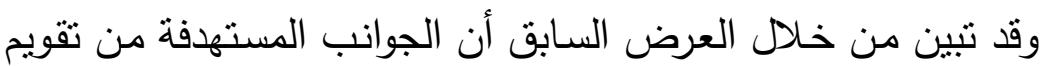

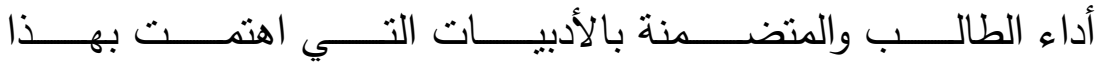
الجانب هي: استخدام التقنية للحصول على المعلومات والخبرات، السلوك التعـاوني، التقكيـر الناقد، التفكيـر التـاملي، مهـارات البحث، مهـارات الاتصـال، المفـاهيم والمصطلحات الأساسية، الجوانب الخلقيـة والتتظيم والالتزام، وبالتالي سوف تدرج هذه الجوانب في أبعاد التقويم المتضمنة بالمقياس الذي سوف يجرى استخدامه بالدراسة الحالية. البعد الرابع: التهيئة التقويم

ويتضمن هذا البعد مقترحات خاصـة بتهيئة المتعلم للتقويم من خلال

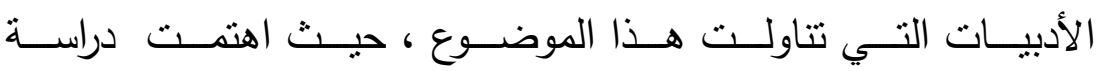
بالتعرف على توجهات طـلاب الجامعات نحو ، (Smith et al.,2008) أوقـات اليـوم المفضـلة في أداء الاختبـارات، وكذلك الفترة الزمنيـة التي لـي

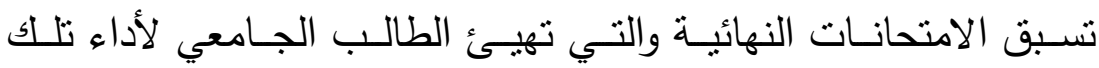

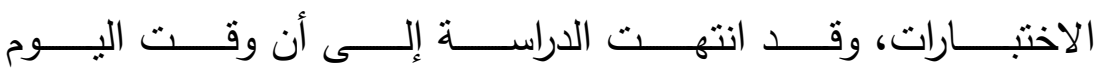


( الصباح، وسط النهار ، المسـاء ) الذي يفضله الطالب لأداء الاختبار

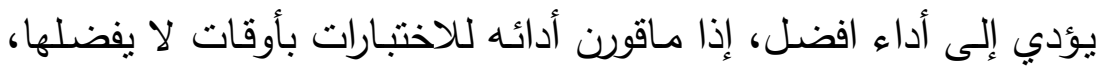

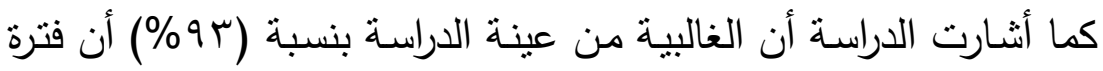

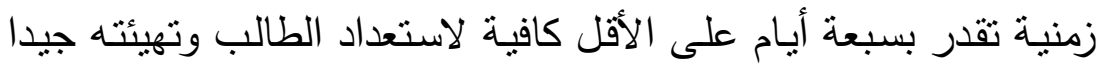

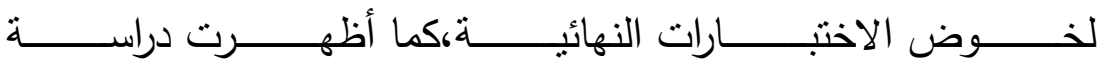
(Hartley \& Nicholls 2009) أن أفضل أوقات اليوم لأداء الامتحانات

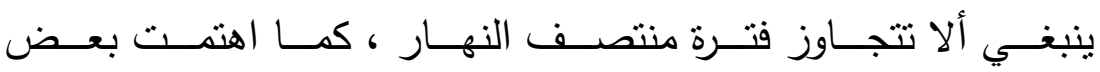
الهيئات واللجان المتخصصة ومن بينها لجنة التعليم بالولايات المتحدة (Education Commission of the States 2010) عن فترة التهيئة السـابقة للامتحانـات، وكان مـن أهم مـا توصلت إليـه

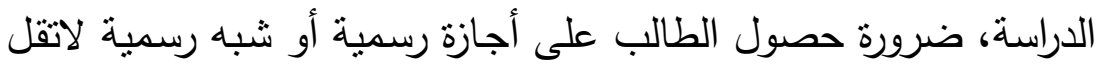

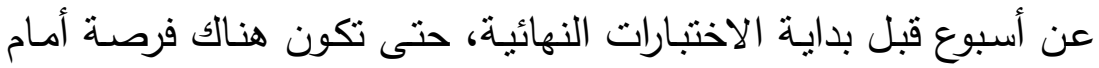

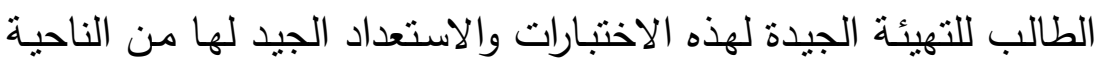
النفسية، وكذللك ضرورة مراعاة الظروف النفسية أو الصحية التي تحول دون أدائهم للامتحانات في المواعيد المقررة لها وأيضا ضرورة قيام المعلم

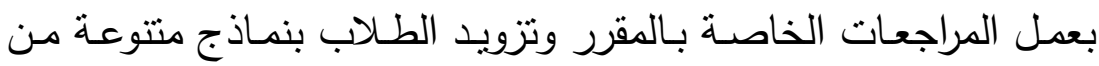

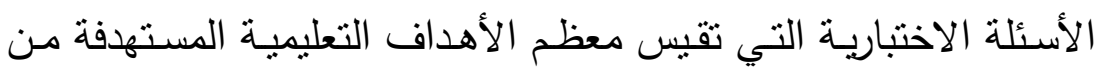

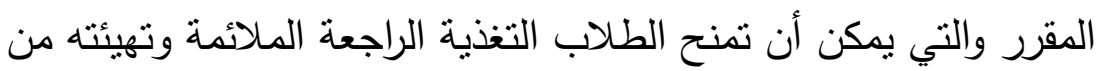

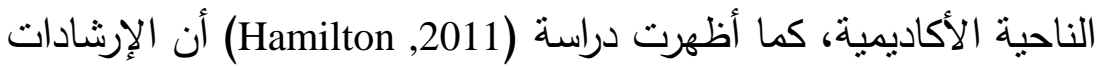

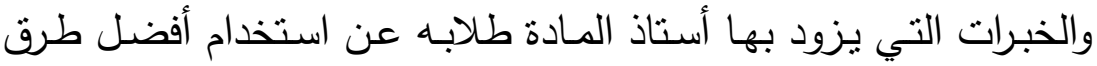
الاستخكار وتجنب الأخطاء الثائعة التي قد يقع بها البعض عند التعامل

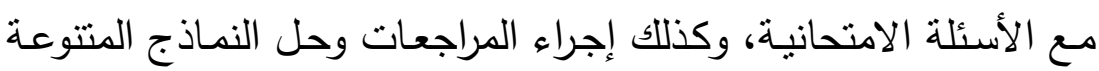

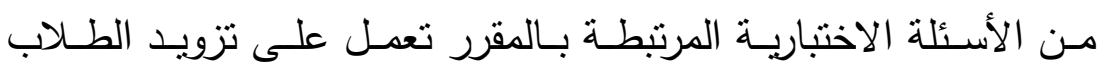

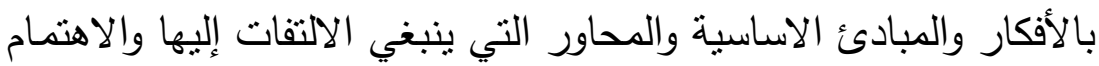

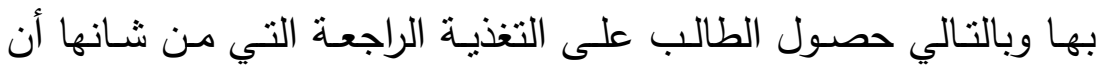


تهيئه بصورة جيدة من الناحية النفسية والاكاديمية كما أنها تعمل على

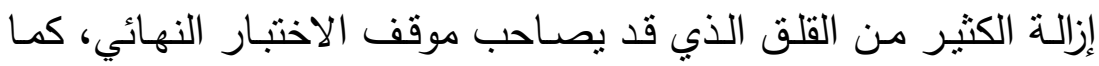
أظهرت دراسة (Michael \& Charles,2010) أن هناك بعض الممارسات من جانب المعلم التي تهيئ الطالب لدخول الاختبار النهائي من بينها

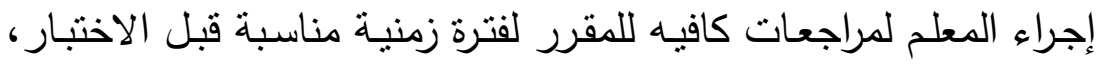

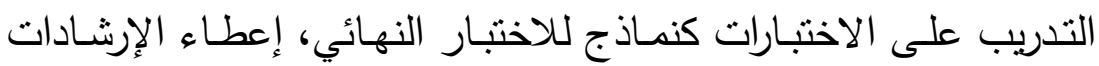

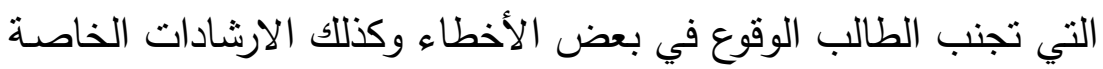
بالاستعداد الجيد للاختبار •

وقد تبـين مـن خـلال العرض السـابق أن إجـراءات نهيئة الطـلاب

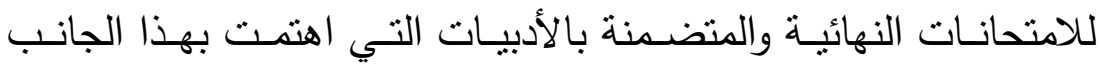
هي:حصول الطالب على أجازة كافية قبل خوض الامتحانات النهائية ،

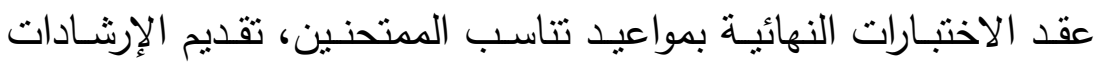
والخبرات عن أفضل طرق الاستذكار وتجنب اللأخطاء الثـائعة التي قد الاعد

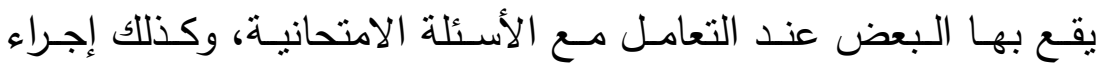
المراجعات وحل وتوفير النماذج المتتوعة من الأسئلة الاختبارية المرتبطة

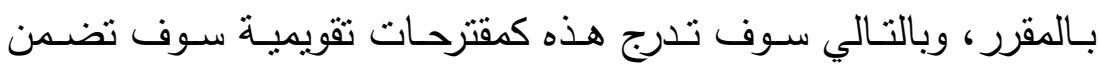
بالمقياس الذي سوف يجرى استخدامه بالدراسة الحالية. البعد الخامس: نظم الامتحانات والمراقبات يضم بعد نظم الامتحانات والمراقبة، وقد ندرت البحوث والدراسات التي تتاولت هذا الجانب، ولم يتم العثور إلا على دراسـة واحدة وهي لعـي

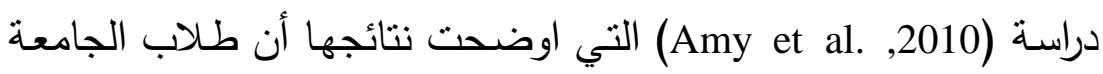
يفضلون توزيع المتحنين عشوائيا على قاعات الاختبار في ضوء الرقم الجامعي للطالب كما يفضلون تلقى الممتحنين بالقاعة الواحدة اختبارات مختلفة أفضل من تلقيهم اختبار واحدا، كما أن عدد الممتحنين في قاعة

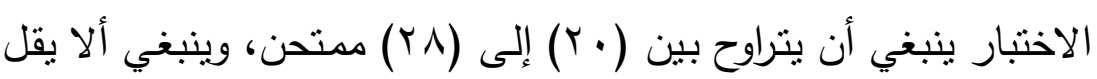


عدد المراقبين داخل اللجنة الامتحانية عن إثنان، كما أن المسافة بين كل مدتحن وآخر ينبغي ألا تقل عن متر طولي، كما يفضل ألا يعقد هذا

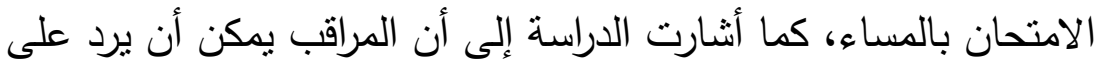

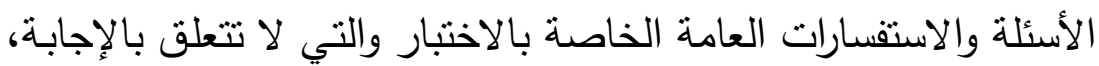

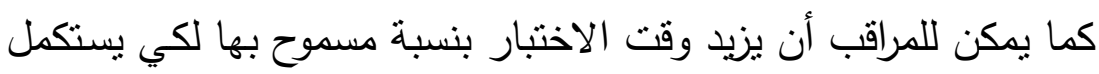

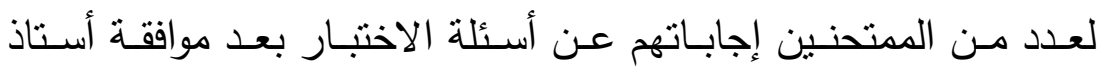

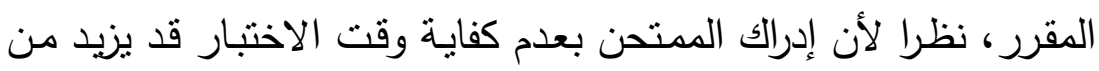
قلقه وتوتره.

وقد تبين من خـلال العرض السـابق أن إجراءات نظم الامتحانـات

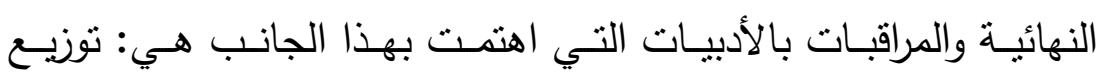
الممتحنين داخل قاعات الاختبار ، عدد الممتحنين داخل قاعة الاختبار

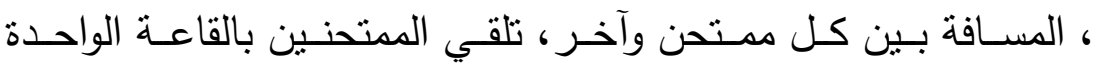

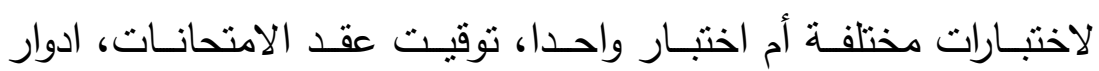

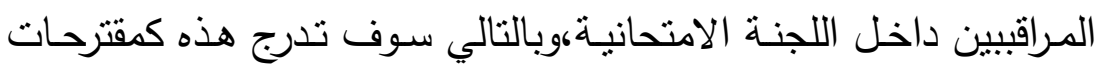

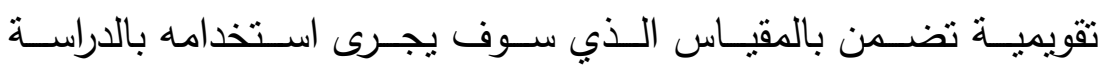
الحالية.ويبدو من خـلال العرض السـابق أن إجراءات التصحيح والتقييم الواردة بالأدبيات التي اهتمت بهذا الجانب هي: أساليب التقييم العادل ،

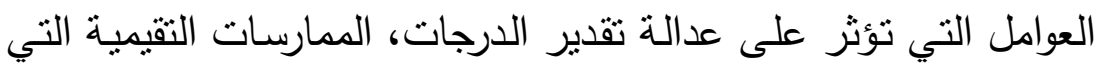
يقوم بها المعلم الجامعي والتي يمكن من خلالها تقدير درجاتهم التقويمية

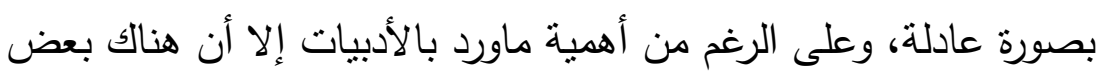
المقترحات الأخرى التي يجب أن تدرج بمقياس الدراسة الأساسية منها:

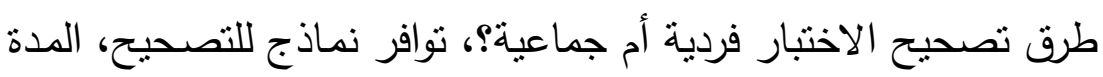

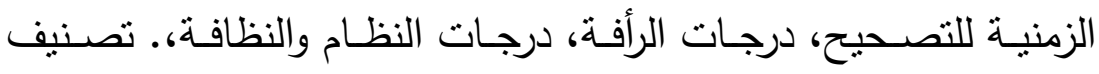
النتائج (ممتاز -جيد جداً -جيد-مقبول-ضعيف)، نموذج إعلان النتائج (درجة كلية - درجات موزعة )، تقرير تقدير الدرجات ( فردي -جمعي ) 
فقرات التقربر تفصيلية أم إجمالية (كيفية -كمية)، وبالنالي سوف تدرج

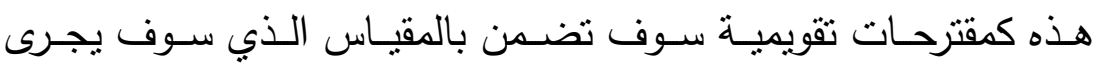
استخدامه بالدراسة الحالية. اتجاهات ونماذج التقويم

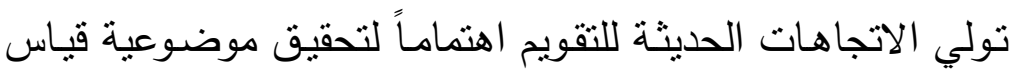

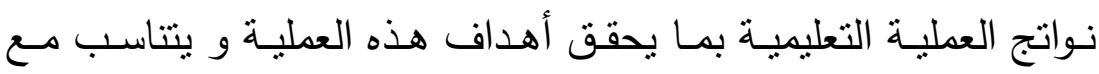
إمكانـات وقدرات المـتعلم ذاتـه و يلبـي احتياجاتـه واحتياجـات مجتمعسه المحلي(Gerard et al.,2008) وحيث أن مخرجات التعلم ونواتج أداء المتعلمين هي محور العملية التقويمية و أهم ركائزها بجميع المؤسسات التعليميـة على مختلف مستوياتها (David et al.,2010) ، ونظرا لأن التقويم التربوي يلعب دورا أساسيا في توجيه العملية التدريسية وإثراء تعلم

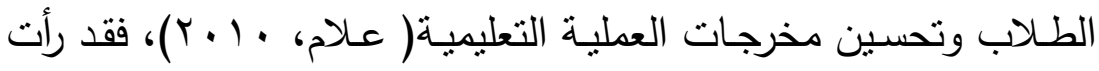
هذه الاتجاهات الحديثة أهمية مشاركة المتعلم نفسه برأيه وفكره في وضع

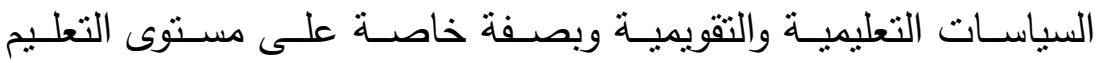

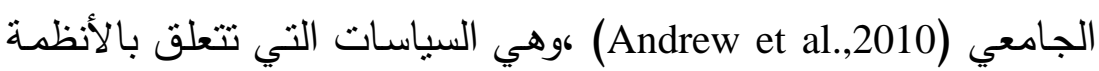

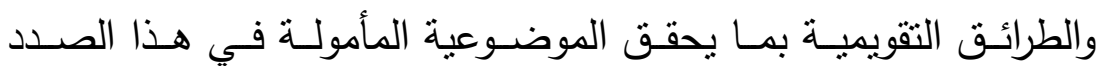
.(Ketterlin-Geller et al.,2009)

وبـالرغم من أن القائمون على العمليـة التقويميـة بـالواقع التعليمي يوجد لديهم مصطلح عام عن التقويم، فإن تباين واختلاف فهم هذا المصطلح

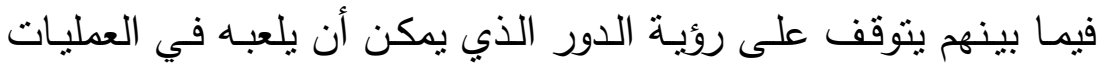
التعليمية (David et al. 2010)، ويعتمد ذللك بدوره على دور المشاركين ( مقوِمين ومقوَمين ) في التعليم وعمليات التقويم المختلفة، وهذا التباين

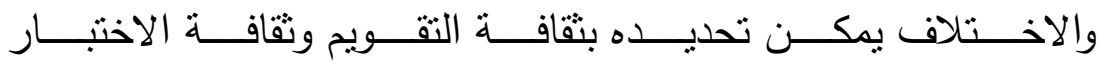
(Birenbaum, 2000)، و تنؤثر تباين هذه الثقافات في تنبي القائم على 
العملية التقويمية لطرق وأساليب وإجراءات ثقويمية تشكل نموذجا تقويميا يختلف عن النموذج التقويمي الذي ينتبناه مُقَّمِ آخر .

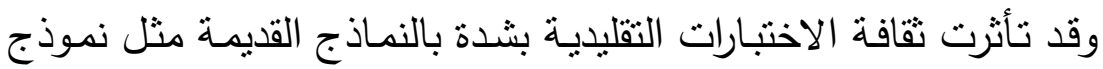

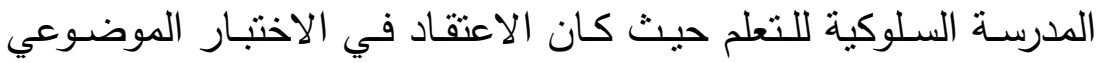

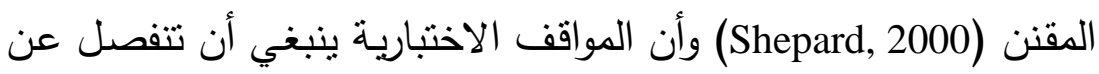
عمليـة التعليم، ونتيجـة لحدوث تطورات في المجتمـع تغير دور وشكل

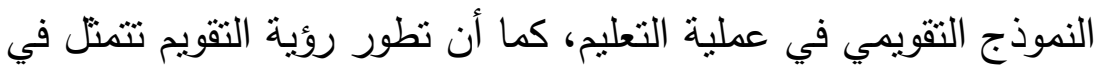
الفكرة التي تتظر إلى التقويم كأداة للنعلم (Baeten et al.,2008) وهي تختلف عن رؤية التقويم في الماضي التي تتظر إليه كوسيلة لتقدير الدرجات، وبالتالي فإن الثقافة الجديدة للتقويم تؤكد بقوة على التكامل بين التعليم والتقويم(Segers et al. 2003) ، وعلى الرغم من ذللك فإن التكامل بين التعليم والتعلم وعمليات التقويم مازال هو التحدي الأكبر لدى كثير من المعلمين(Struyf et al. 2001) ، فلقد أشـار (1999, Glasner) إلى هوري أن هناك مجموعة عوامل تتكل أسباب لمنل هذه التحديات من بينها ولاء المعلمين للطرق التقليديـة ومقاومتهم للتجديــ ممـا يتسبب في انتشـار الاختبارات التقليدية وتنني النموذج التقويم القديم وبالتالي غياب الانتشار الواسع للابتكار والتجديد (Kuhlemeier et al., 2004). ونظراً أن التقويم يلعب دورا فاعلا في عمليات التعلم تبعا لتأثثر طرق التعلم الجديدة، Watering \& Rijt 2006) فإن تهيئة المتعلمين انفسهر للتقويم تعتمد على كيف يكون إدراكهم لطبيعة هذا التقويم مدا يكون له تأثيرات بالسلب والإيجاب على عملية التعلم.

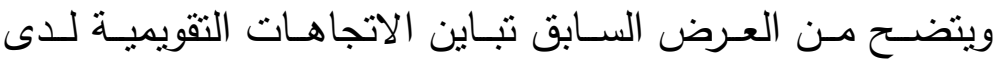

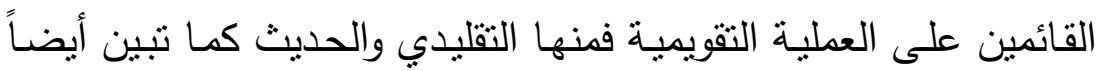
تباين واختلاف طرق ووسائل ومراحل التقويم وهذا التباين والاختلاف

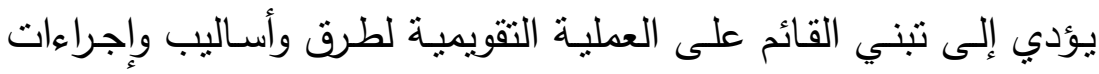


تقويمية تتكل نظاماً تقويميا يختلف عن النظام التقويمي الذي يتبناه هُقَوِم

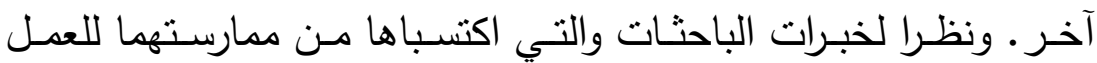
الأكاديمي بكل التربية بجامعة الملك سعود لعدة سنوات، فقد تبين لهما

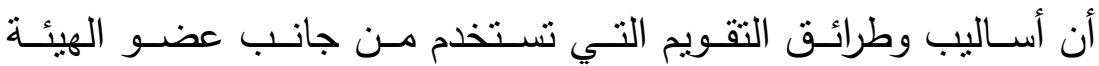
التدريسية في تقويم أداء الطالبة الجامعي لاتتبع من نظام تقويمي محدد

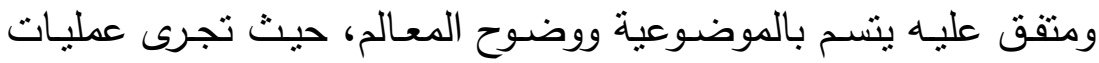

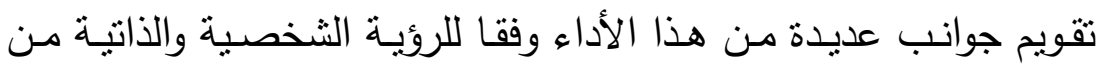
جانب عضو الهيئة التدريسية وبالتالي تختلف وسائل وطرائق وأسـاليب التقويم كمـا تختلف الجوانب التقويميـة المستهدفة في أداء الطالب مـن عضو لآخر من أعضاء الهيئة تدريسية، مما يؤثر على دقة وموضوعية

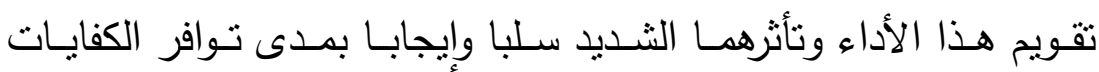
التقويمية لعضو الهيئة التدريسية وخبراته ونضوجه العلمي والمهني، كما أن هناك اختلافات كثيرة وجوهرية بين أساتذة المقررات الدراسية بمختلف وهيك مستويات الدراسة فيما يستخدمونه من طرائق وأدوات واساليب في تقويم أداء الطالب الجـامعي، فمنهم مـن يركز على الجوانب المعرفيـة فقط، ومنهم من يهتم بالجوانب الإنفعالية والأخلاقية، ومنهم من يهتم بالأسئلة

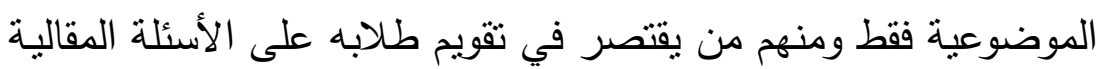

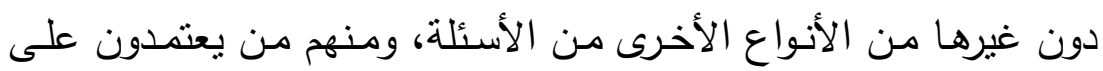

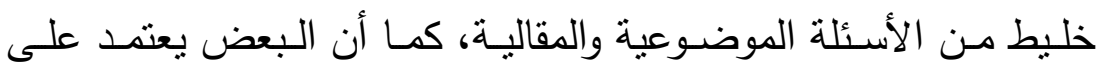
الاختبارات التحريرية فقط دون الثفهية كما تختلف مراحل التقويم وطبيعة هذه المراحل من مقوم لآخر حيث يعتمد البعض على اختباران فصليان

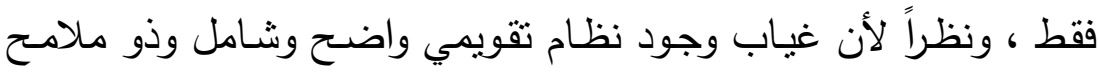

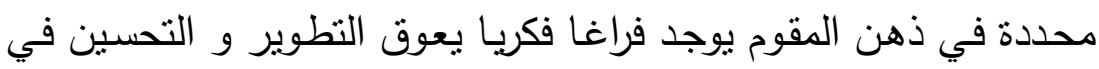

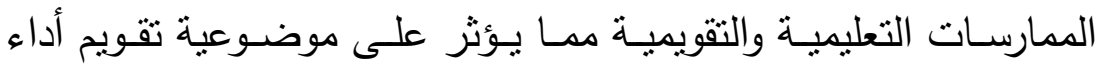

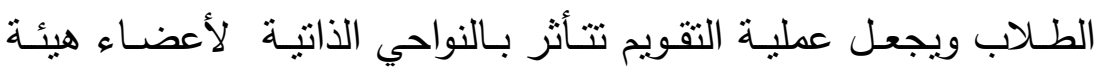


التـدريس (Eisner,1996) ونظــرا لأن الاتجاهـات الحديثـة تـولي أهميـة

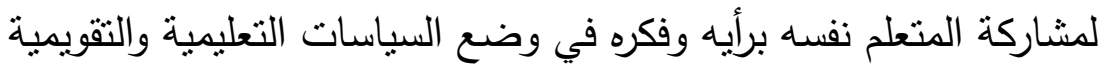

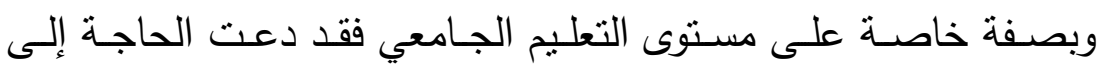
ضرورة إجراء دراسـة علمية تستهدف عرض أسـاليب تقويم أداء طالبات كلية التربية، من خـلا الروئية التقويميـة لهن، وبالتنالي يمكن الحصول

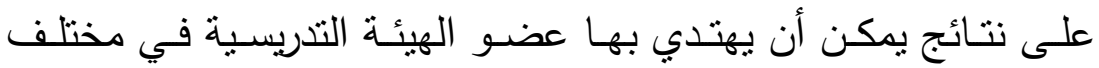
عمليات وإجراءات التقويم وكذلك القائمون على العملية التقويمية بالكلية بما قد يوفر مستقبلا معايير تقويميـة موحدة في ضسوء معايير الجودة العالمية والاطار المفاهيمي وبما يؤدي إلى تحقيق موضوعية قياس هذا

الأداء.

مشكلة الاراسة

تتلخص مشكلة الاراسة في الإجابة على السؤال العام التالي :

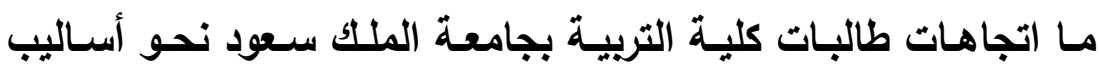
التقويم المستخدمة فعلياً في تقويم أدائهن و التي تتسث ونظم الاعتماد

الأكاديمي؟

وتتقرع من هذا السؤال الأسئلة الفرعية التالية :

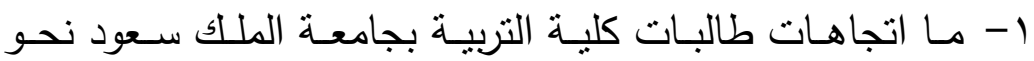

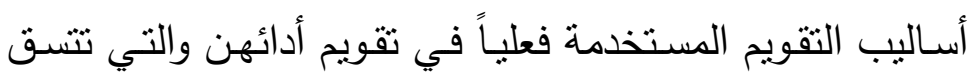

ونظم الاعتماد الأكاديمي؟

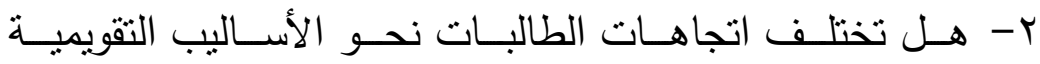

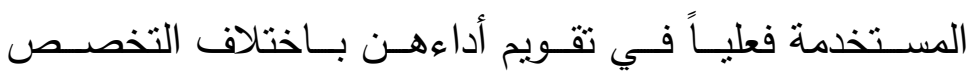

(علم نفس - تربيـة خاصـة -رياض أطفال -تقافة إسـامية-

تربية فنية)؟ 
r- هـل تختلـــ اتجاهـات الطالبــات نحــو الأسـاليب التقويميــة

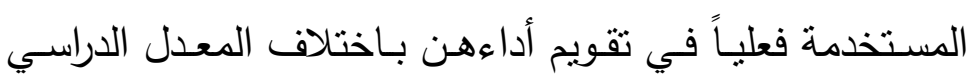

$$
\text { (منخفض -منوسط -مرتفع)؟ }
$$

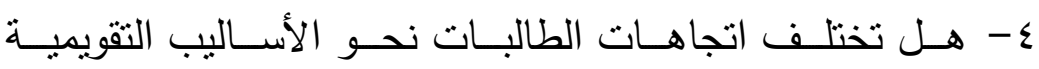
المستخدمة فعلياً في تقويم أداءهن اختلاف المسنوى الدراسـي

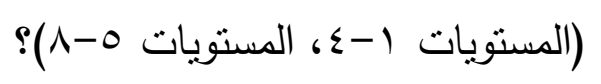

مصطلحات الدراسة

الاتجاه

تشير الاتجاهات إلى نزعات تئهل الفرد للاستجابة بأنماط سلوكية محددة، نحو اشخاص او افكار او حوادث او اوضـاع او اشياء معينة،

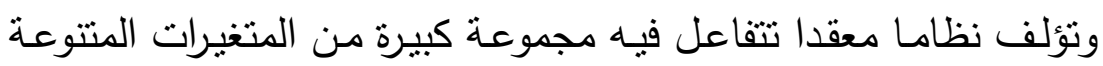

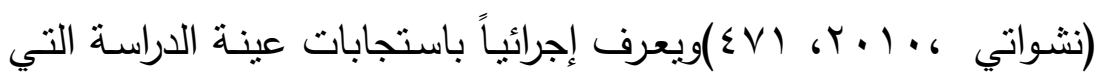

تظهر موافقتهم أو رفضهم لمضامين فقرات الأداة المستخدمة بالدراسة.

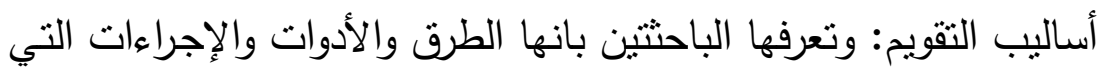

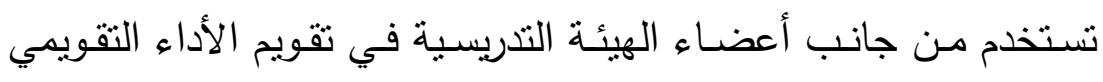
لطالبات كلية التربية

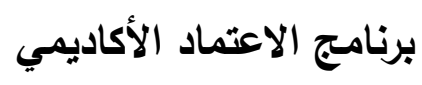
يعتمد برنامج الاعتماد الأكاديمي على معايير للتقويم تتلخص في الادي النقاط التالية: - النية

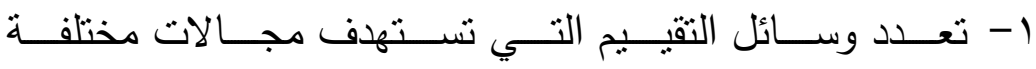
(الاستقصاء والبحث - الإتقان - التفكير الناقد - التعلم الحقيقي النشـط - التقكر في الممارسـات - تقيميم اسـتخدام التقنيـات -

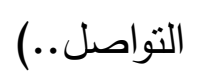

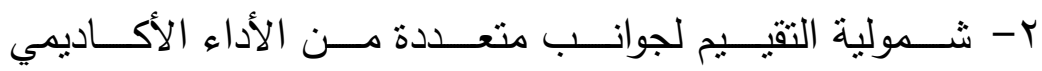

$$
\text { ( معرفي - نفسي - اجتماعي ....). }
$$




$$
\begin{aligned}
& \text { r- التتوع في طرق التقويم ( تمهيدي - تكويني - ختامي). } \\
& \text { ع- تقييم الأنشطة التعليمية (الفردية - الجماعية). }
\end{aligned}
$$

0- استمرارية التقييم.

צ- تقييم تطبيق المعلومات في مواقف حياتية.

\section{أهمية الدراسة}

\section{تبدو أهمية هذه الدراسة في النقاط التالية:}

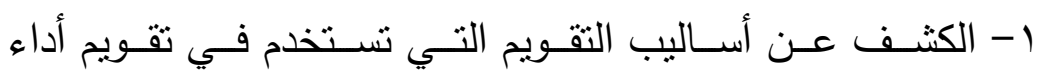

الطالبات، لـه أهميته في تقييم كل من الواقع التقييمي وفعاليـة

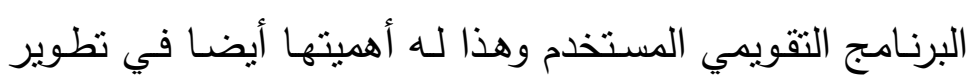

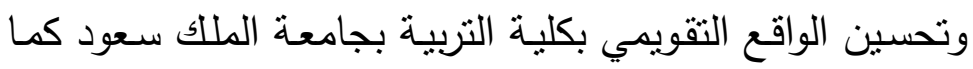

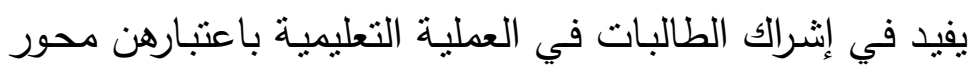

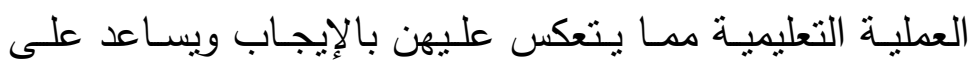
تتمية الشخصية لديهن.

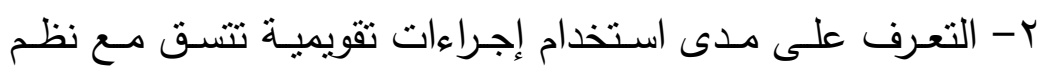

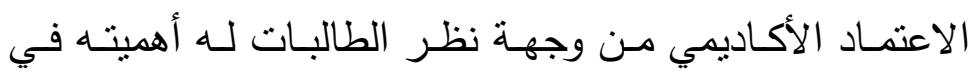
تحديد مدركات وتوجهات الطالبـات نحو معـيير الجودة التي لهي تستخدم في الواقع الفعلي ومما قد يساعد في إدرالك المسؤولون عن التقويم في الكثف عن الحقائق وفهم هذا الواقع بشكل أكثر

$$
\text { دقة وواقعية. }
$$

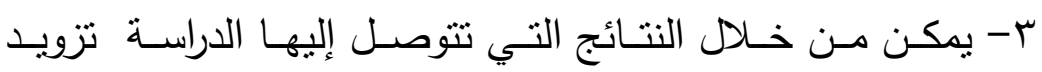

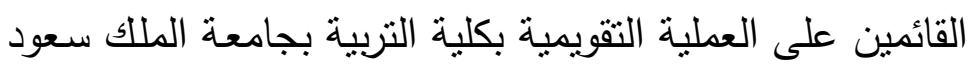
بالمعطيات والحقائق التي تمكنهم من تطوير البرنامج التقويمي لئه المستخدم في الواقع الفعلي بصورة أكثر فاعلية وإيجابية. 


\section{أهداف الدراسة}

تتمنل أهداف الدراسة الحالية فيما يلي:

1- الكثف عن أساليب التقويم التي تستخدم في تقويم أداء الطالبات.

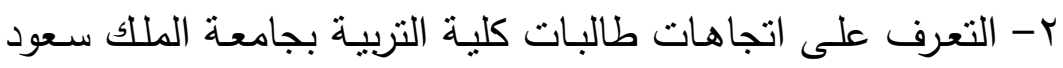

نحو أساليب التقويم المستخدمة فعلياً في تقويم أدائهن.

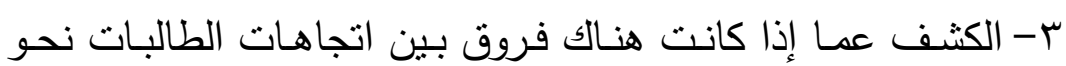

أساليب التقويم التي تستخدم في تقويم الطالبات وفقا لنظم الاعتماد

الأكاديمي تبعا لاختلاف التخصص.

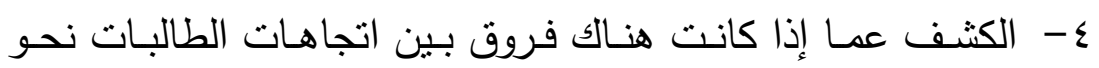

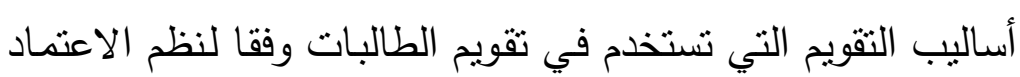

الأكاديمي تبعا لاختلاف المستوى الدراسي.

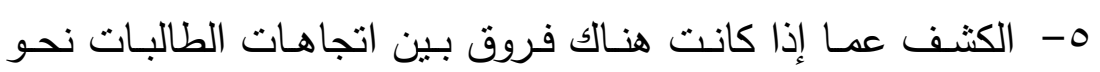

أساليب التقويم التي تستخدم في تقويم الطالبات وفقا لنظم الاعتماد

الأكاديمي تبعا لاختلاف المعدل الدراسي.

حدود الدراسة ومبرراتها

1-اقتصرت الدراسة الحالية في إجراءاتها الحالية على عينة من طالبات

كلية التربية بجامعة الملك سعود.

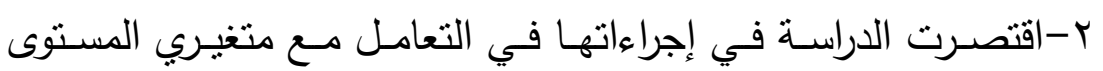

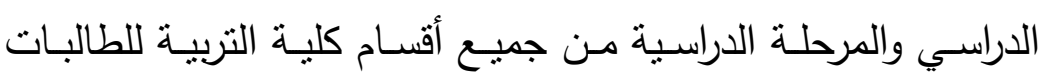
بهـدف الحصـول على عينـة تمثنل مجتمـع طالبـات كليـة التربيـة

$$
\text { إجراءات الدراسةة جيدة. }
$$

تتوزع عينة الدراسة الحالية على طالبات البكالوريوس و اعتمدت على عينة عشوائية من طالبات كلية التربية بجامعة الملك سعود وبعد 
فرز المقاييس تم استبعاد عدد كبير من المقاييس التي كانت غير مكتملة

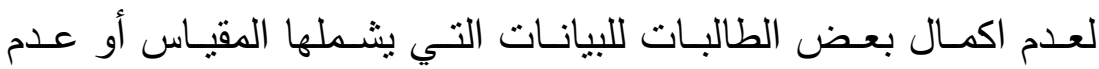
الاستجابة على جميع الفقرات وتم الابقاء على المقاييس التي اجابت الطالبات على جميع فقراتها وقامت باستكمال البيانات حيث بلـغ حجم

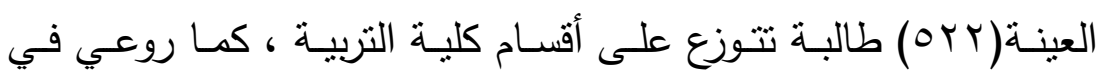
خصائص العينة المستوى الدراسي والمرحلة الدراسية والتخصص والمعدل الدراسي.

جدول (1) توزيع مفردات عينة الدراسة وفق متغيرات الدراسة

\begin{tabular}{|c|c|c|c|}
\hline النسبة & التكرار & المستوى الدراسي & المتغير \\
\hline$\% \leq r$ & $r r$. & علم نفس & \multirow{6}{*}{ (التخصص) } \\
\hline$\% r v$ & 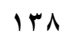 & رياض أطفال & \\
\hline$\% r$ & ir & ثقافة إسلامية & \\
\hline$\%$ \%ч & $1+4$ & تربية خاصة & \\
\hline$\% r$ & 17 & تربية فنية & \\
\hline$\% 1 \ldots$ & OrY & المجموع & \\
\hline \%rч & $1+4$ & $\varepsilon-1$ & \multirow{3}{*}{ المستوى } \\
\hline$\% \vee \leqslant$ & rA & $\Lambda-\bullet$ & \\
\hline$\% 1 \ldots$ & Orr & المجموع & \\
\hline$\% 1 \leq$ & $v_{1}$ & منخفض & \multirow[t]{4}{*}{ المعدل } \\
\hline$\% 11$ & 07 & متوسط & \\
\hline$\%$ V० & rqo & مرتفع & \\
\hline$\% 1 \ldots$ & Orr & المجموع & \\
\hline
\end{tabular}

المنهج المستخدم في الدراسـة الحاليـة هو الدنهج الوصفي التحليلي المقارن، حيث سيتم الكثف عن أساليب التقويم التي يتم استخدامها حالياً من قبل عضوات هيئة التدريس في جميع الأقسام بكلية التربية في تقويم

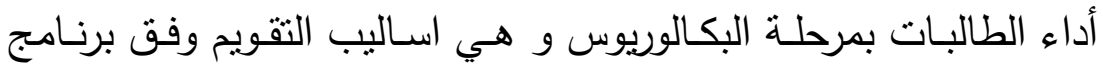

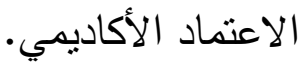


أداة الدراسة

تعتمد الدراسـة في تحقيق أهدافها على مقياس للتعرف على وجهة

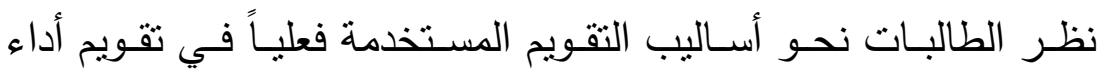

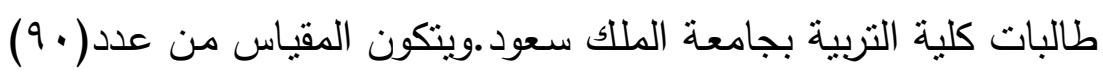

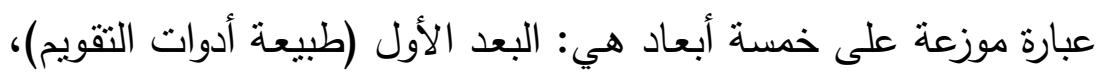
والبعد الثاني (مراحل ووسـائل التقويم) والبعد الثالث (جوانب ومجالات لئل التقويم) والبعد الرابع (التهيئة للتقويم)، والبعد الخامس (نظم الامتحانات). والجدول التالي يوضح توزيع أسئلة الأداة على أبعادها الخمسة. جدول (r) أبعاد مقياس آتجاهات الطالبات نحو إجراءات ووسائل تقويم أداء الطالبة الجامعية بكلية الجادية التربية بجامعة الملك سعود

\begin{tabular}{|c|c|c|}
\hline عدد البنود & المسمى & البعد \\
\hline q & طبيعة أدوات التقويم & (1) \\
\hline 17 & مراحل ووسائل التقويم. & (2) \\
\hline 17 & جوانب ومجالات التقويم & (3) \\
\hline 9 & التهيئة للتقويم & (4) \\
\hline ir & نظم الامتحانات. & (5) \\
\hline 9. & المجموع & \\
\hline
\end{tabular}

التحقق من الخصائص السيكومترية لأداة الدراسة الأساسية

بعد الانتهاء من إعداد المقياس بصورته النهائية تم تطبيقه على عينـة من طالبات كلية التربية ( . . ( طالبة ) للتحقق من بعض الخصـائص

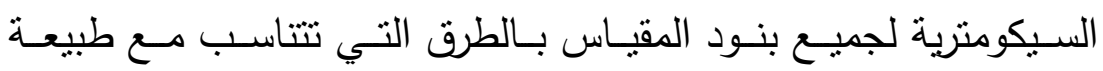

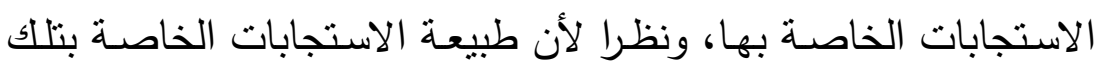

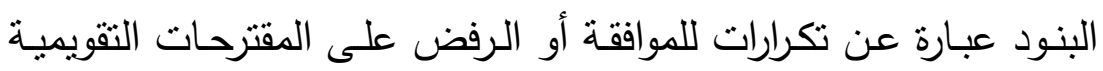
المتضمنة بهذه البنود فقد استخدمت الدراسة طريقة إعادة تطبيق المقياس البـاس في تقدير ثبات فقراته ثم استخدام اختبار ويلكوكسون للتعرف على دلالة الفرق بين تكرارات استجابات الموافقة والرفض للطالبات في القياسين لكل 
بعد من أبعاد المقياس وذللك بعد إعادة تطبيقة على نفس العينة بفاصل

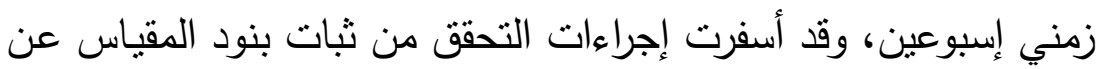

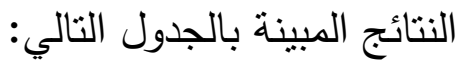
جدول (ץ) قيم اختبار ويلكوكسون ودلالتها للفروق بين تكرارات الموافقة والرفض لبنود أبعاد مقياس الاراسة الأساسية لمرتين تطبيق المقياس

\begin{tabular}{|c|c|c|c|}
\hline \multicolumn{2}{|c|}{ قيم اختبار ويككاكسون ( 2 ) ودلالتها } & \multirow[t]{2}{*}{ البعد } & \multirow[t]{2}{*}{ مسلسل } \\
\hline مستوى الدلالة & قيم (z) للبنود & & \\
\hline $.701-. . \wedge \leqslant \tau$ & $\ldots r r-1 . . r$ & الأول: طبيعة أدوات التقويم & (1) \\
\hline .ror $-.0 \leqslant$ r & 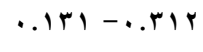 & الثاني: مراحل ووسائل التقويم. & $(\stackrel{r}{)}$ \\
\hline $.901-. .0 \leqslant r$ & $\ldots 9 \vee-1 . .4$ & الثالث: جوانب ومجالات التقويم & $(\boldsymbol{r})$ \\
\hline$. . r T r-. .0 \leqslant v$ & ..Ar-.rul & الرابع: التهيئة للتقويم & $(\varepsilon)$ \\
\hline$. . Y 4 \wedge-\ldots \leqslant \wedge 9$ & ..11T-..rYs & الخامس: نظم الامتحانات والمراقبات. & (०) \\
\hline
\end{tabular}

ويتضـح من الجدول السابق أن جميع قيم اختبار ويلكوكسون لبنود

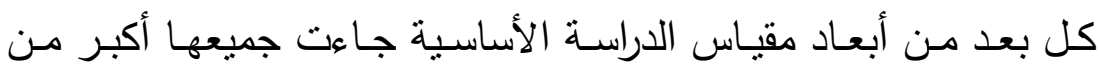

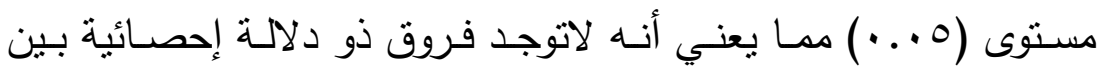

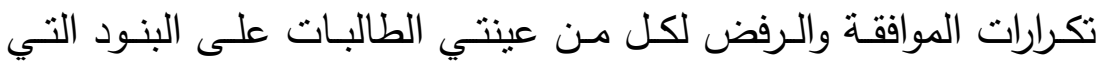

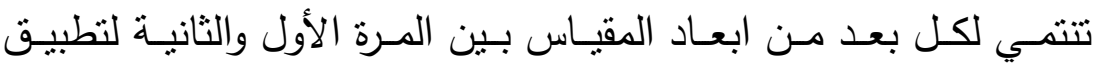

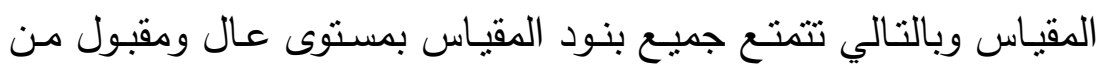
الثبات، كما تم حساب معامل الفاكرونباخ للمقياس وابعادة وبلغت قيمة بـاس معامل الفاكرونباخ للمقياس ككل (• •, •) كما تراوحت قيم معاملات الفا للابعاد مابين (V9, • إلى ح VY, • ) مما يدل على تمتع مقياس اتجاهات

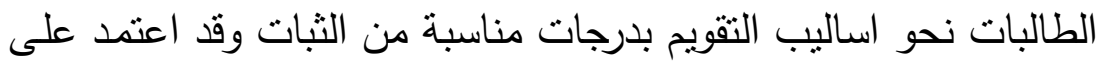

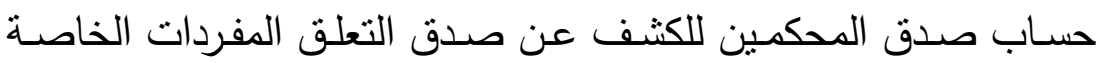
بالأبعـاد التي تتنــي إليهـا وكذللك صـدق تعلقهـا بالإطـار المفـاهيمي ومعـايير الجـودة العالميـة ( NCATE) باسـتخدام طريقـة نسـب اتفــاق المحكمين على صدق بنود المقياس، وقد جـاءت نسب موافقات عينـة 
المعلم (المحكمين ) على صدق بنود المقياس وانتماؤها للبعد التي تتنمي إليه وإرتباطها بالإطار المفاهيمي المحدد من فبل الكلية ومعايير الجودة لهن

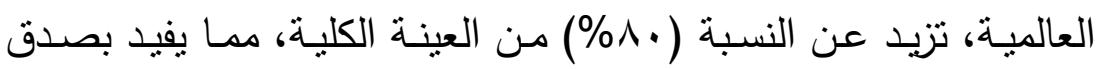
البنـود فيمـا تقيسـه وبالتتالي يتمتـع المقيـاس بمستوى مقبول مـن الثبات

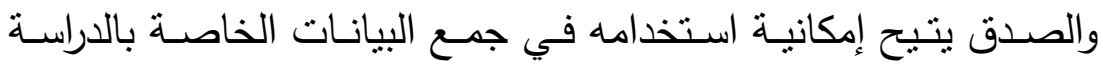
بدرجة عالية من الثقة. ويوضح جدول رقم () قائمسة المحكمين للاداة في ملاحق الدراسة . ماسه

\section{الأساليب الإحصائية المستخدمة في الاراسة الحالية}

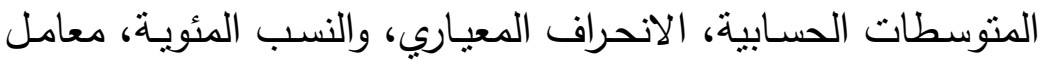
ألفا كرونباخ، والرتب، والتكرارات، ومعادلة (Z) لدلالة الفروق بين نسبتين المعدلة باختبار بنفروني، اختبار مربع كاي لدلالة الفروق بين التكرارات.

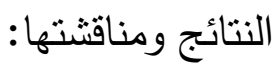

لقد أسفرت إجراءات الإجابة عن أسئلة الاراسة عن النتائج التالية اولا: عرض ومناقثنة النتائج الخاصـة بإجراءات الإجابة الخاصة بالسؤال

1-لقد أسفرت إجـراءات الإجابـة عن السؤال الأول الذي ينص على:

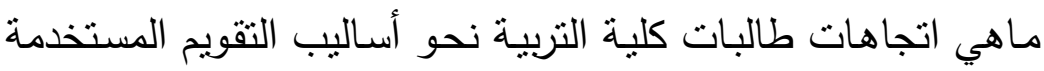
فعلياً في تقويم أدائهن والتي تتسق ونظم الاعتماد الأكاديمي؟ عن الجن

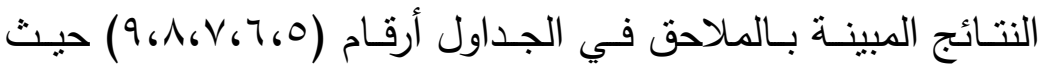
يتضــن كـل جدول مـن هـذه الجـداول التكـرارات والنسـب المئويـة لاستجابات العينة الكلية للدراسـة على جميع أبعاد الأداة المستخدمة

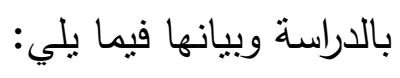

أ- البعد الأول (التفضيلات الخاصة بالاختبارات)

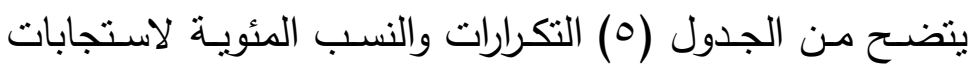

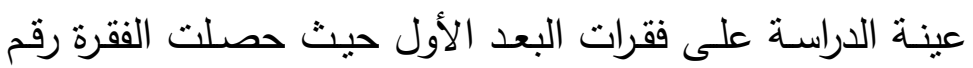


"كلما كان الاختبار يحتوى على أسئلة كثيرة ومتنوعة كان (YT)

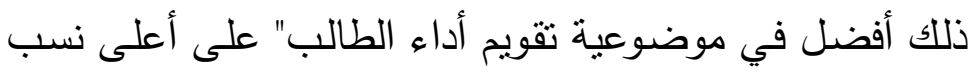

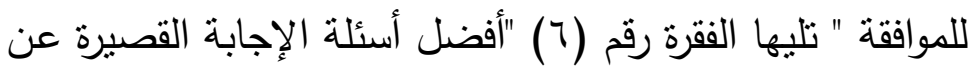

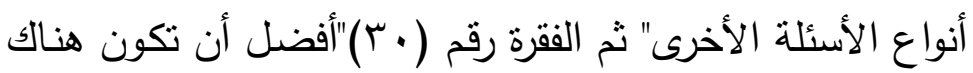
درجات خاصة لنقويم الطالب تعطي للانضباط داخل المحاضرة والالتزام بالسـلوك الأخلاقي " ثم الفقرة رقم (r) "أفضـل أسئلة

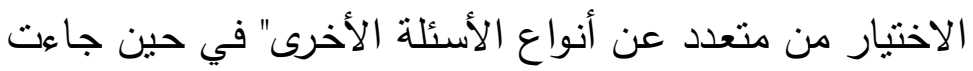

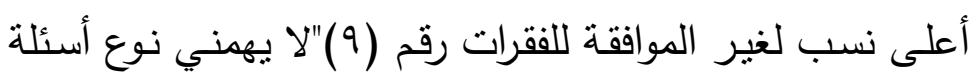

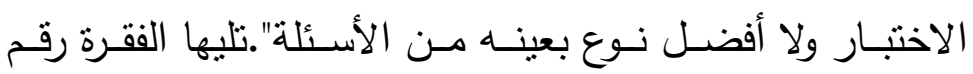

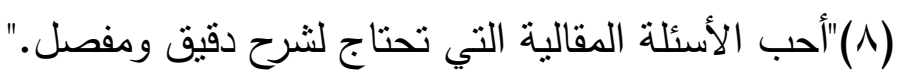
هذا ويتضـح من النتائج بشكل عام وجود اتجاهـات إيجابيـة لعينة الدراسة الكلية نحو الأسئلة الموضوعية وقد يفسر تفضيل الطالبات لهذا النوع من الأسئلة نظرا لأنهن يحصلن بمقتضاها على مزيد من الدرجات الدات

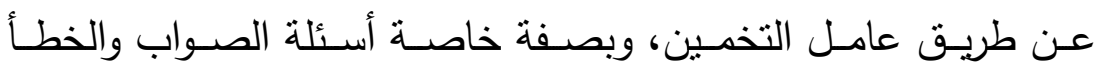
a أوض i

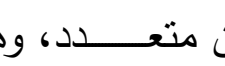

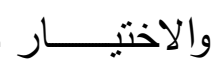
(Gellman \& Berkowitz, 2008)، كما أن هذه الاختبارات تتضمن أسئلة

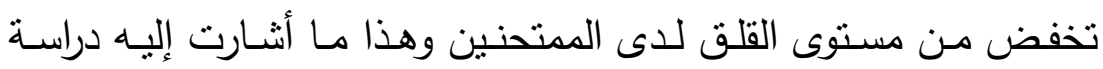

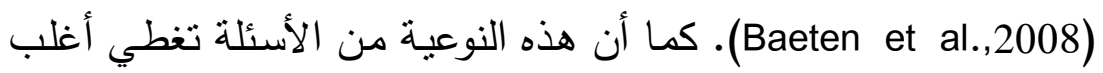

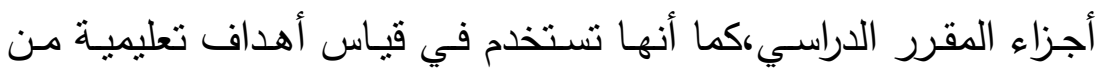

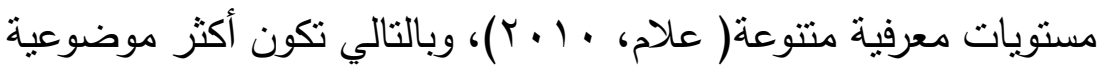

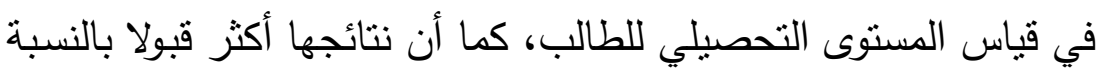

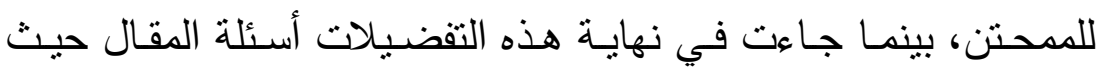

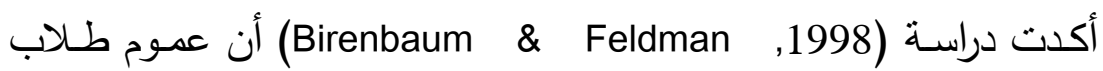
الدراسات العليا لا يفضلون الاختبارات المقالية وحدها، على الرغم من أن الأسئلة المقالية تتاسب مستويات مهمة في التحصيل تتمثل في مجال 


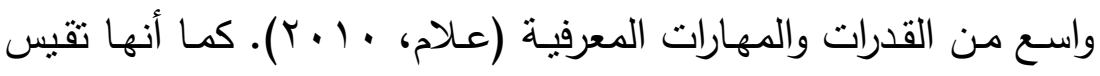

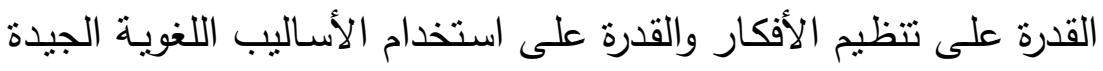

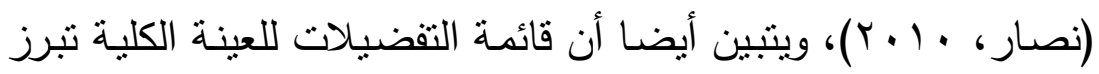

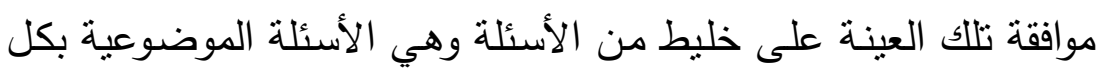
انواعها وكذلك الأسئلة المقالية وهذا يعني أن هذين النوعين من النئ وهي الأسئلة

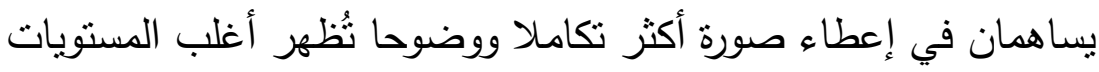

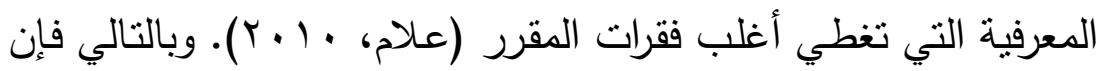

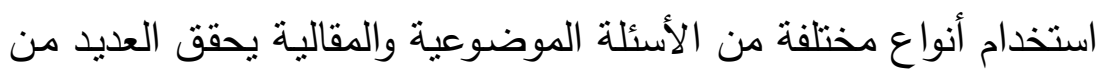

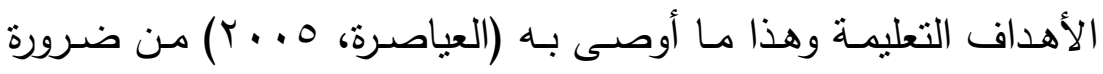

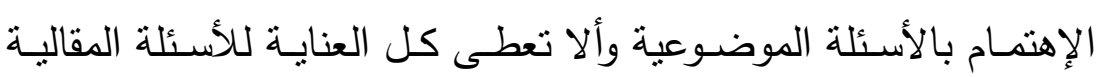

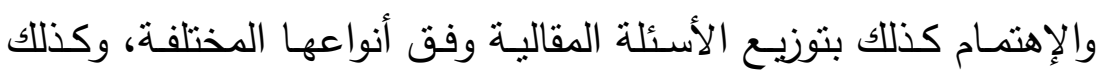
ضرورة تتويع الأسئلة الموضوعية لأن كل نوع منها يحقق أهداف من مجالات مختلفة.

ويتبين من النتائج السابقة أن أغلب التفضيلات الخاصة بالعينة الكلية جاءت للأسئلة التي تغطي جميع أجزاء المقرر ، وهي الميزة التي

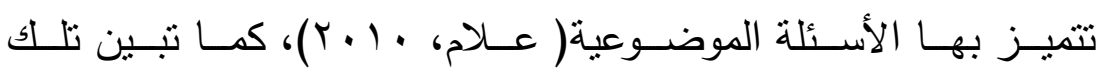
التفضيلات أيضا الأسئلة التي تعتمد على التطبيق و توظيف المعلومات والتي يمكن أن تبرز النواحي الابتكارية لدى الطالب ولا تعتمد على السرد

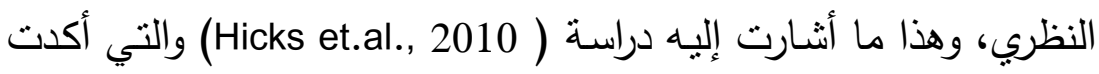
على تفضيل طلاب الجامعة لهذه النوعية من الأسئلة، كما اشتملت قائمة

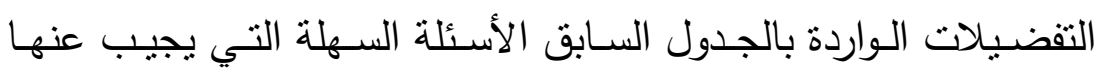
غالبية المتحنين، وكذلك الأسئلة التي لا تستغرق وقت كثيرا في التفكير ،

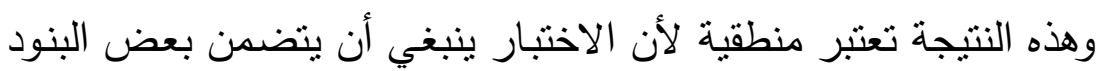

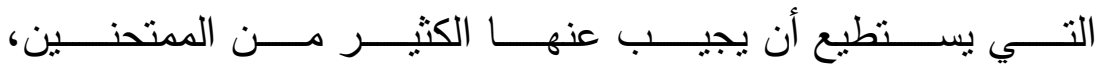

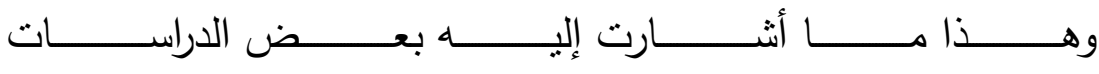


‘(Birenbaum\& Feldman ,1998; Beller \& Gafni, 2000 ;Traub \& McRury, 2010) إلى تفضيل طلاب الجامعة للأسئلة البسيطة وغير المعقدة وهي الأسئلة التي لا تتطلب بطبيعتها وقتا كثيرا للتفكير • ويتبين من خلال قائمة التفضيلات المعروضة بجدول (rT) أن العينة الكلية تفضل التتوع في أسئلة الاختبار بحيث لاتقتصر على نوع واحد من الأسئلة الموضوعية بل ينغي أن تحتوي على انواع متعددة منها كما أن أسـئلة الاختبـار ينبغـي أن تكـون مزبجـا مـن الأسـئلة الموضـوعية والمقالية، ويمكن الاعتمـاد على الاختبارات المقالية القصيرة في التحقق من مدى إنجاز الأهداف التعليمية الخاصـة بكل موضوع دراسي، وهذا يفيد بوعي العينة الكلية بأن التتوع في الأسئلة يساهم في إعطاء صورة أكثر تكاملا ووضوحا عن أداء الطالب، كما أنها تظهر أغلب المستويات المعرفية التي تغطي أغلب أجزاء وفقرات المقرر (علام، . • ب) .كما

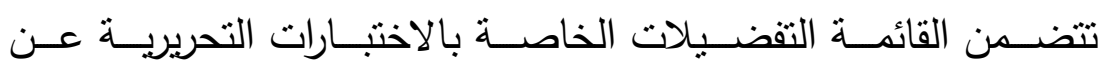
الاختبـارات الثـفهية، نظـرا لأنها تخفض مـن معدلات القلق والضـغوط النفسية التي يتعرض لها الممتحنين مـع الاختبارات الثفهية وقد اتسقت تفضـيلات هـذه النوعيـة مـن الاختبـارات مـع مــا أثـارت إليـهـ دراسـة (wheeler \& Berkowitz,1993)

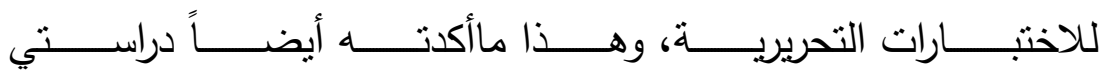
كما اشـارت أيضـا (Traub \& McRury ,2010،Gerard et.al., 2008) دراسـة (Sasmaz et.al., 2011) أن معلمسي الجامعـة يعتقدون أن الاختبـارات التحريريــة هـي أكثر شـمولا وموضــوعية مـن الاختبـارات الثفهية، كمـا تبين مـن نفس القائمسة السـابقة عدم تفضبيل العينـة الكليـة للاختبارات الثفهية أو أن تخصص لها درجات ذات وزن أكبر ،وقد يبدو ذلك أمرا منطقيا نظرا لعدم شمول أسئلة هذه النوعية من الاختبارات على أغلب أجزاء المقرر كما أنها نتاثز ببعض المتغيرات النفسية التي يمكن 


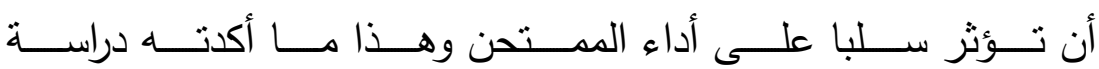
Sasmaz et al., 2011)

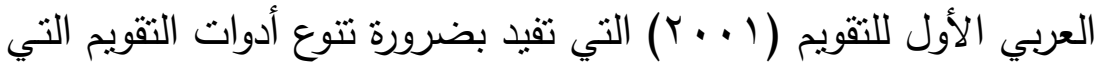
تستخدم في تقويم الطالب لتشمل: الاختبارات التحريرية والثفوية وأساليب الملاحظة وغيرها من الأساليب الأخرى. أ- البعد الثاني (مراحل ووسائل التقويم) يتضــح مـن الجـدول (؟) فـي الملاحـق التكـرارات والنسـب المئويـة لاستجابات عينة الدراسة على فقرات البعد الثاني حيث حصلت الفقرة رقم

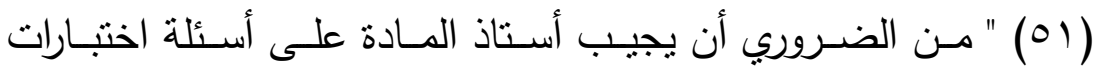

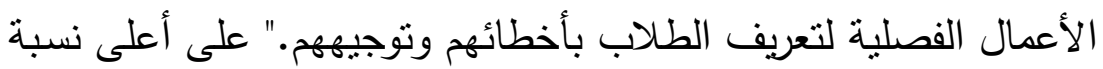

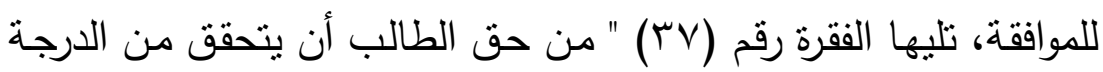

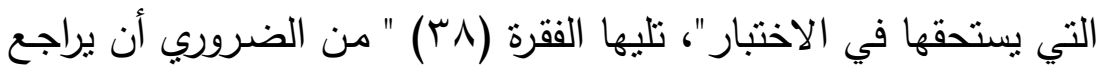
الطالب إجاباته عن أسئلة الاختبار بهدف التعرف على مواطن وأوجها القصور لديه".ثم الفقرة (ץ §) " يجب أن يعطى الطالب الفرصة لتحسين

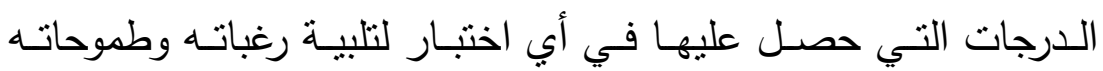
الثخصية." في حين جاءت أعلى نسب لغير الموافقة للفقرات رقم (1) "يجب أن يحتوي الاختبار على أسئلة لا يستطيع أن يجيب عنها سواي" لئرئ

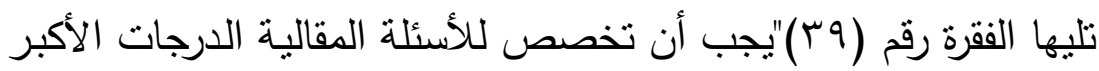
عن الأسئلة الموضوعية". وقد تبين من قائمسة التفضيلات بشكل عام تفضيل العينة الكلية أن الن النيل

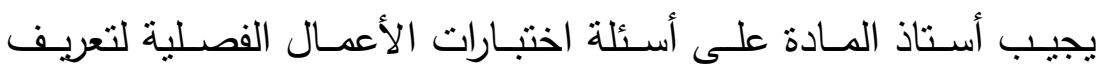

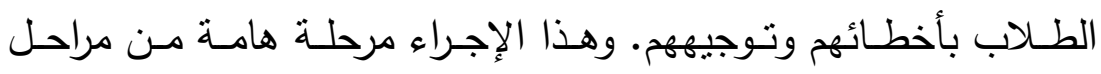
التقويم التكويني بجانب التجميعي فقد تبين من خلال الأدبيات أنها نؤدي إلى تحسين قدرة الاحتفاظ بالمفاهيم. وإعطاء التغذية الراجعة المناسبة لهنية

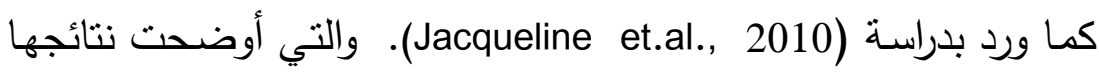


أن إدرالك المتعلم لأخطائهه من خـلال نتائج الاختبارات يؤدي إلى تقديم

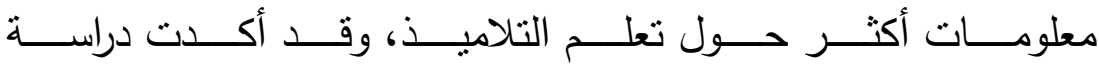
(Tang \& Harrison,2011) والتي تهتم بتحديد اوجه الضعف ونواحي القصور للدى الطالب وإدراكه

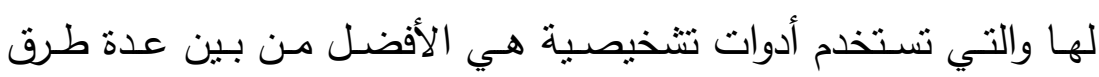

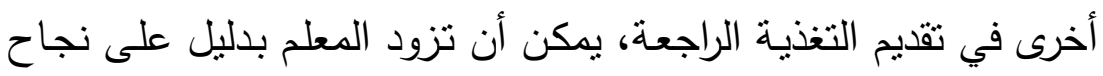

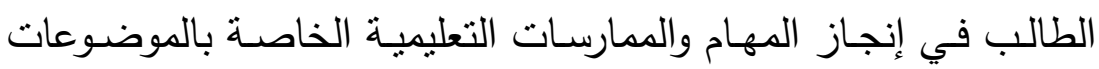
المستهدفة.

وقد تبين أيضا عدم موافقة العينة الكلية على الفقرة (1 (ـ) "يجب أن

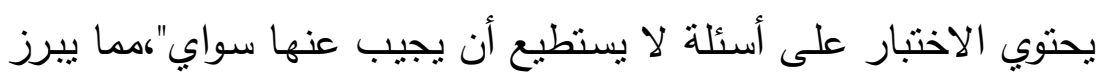

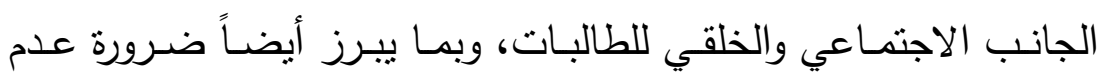

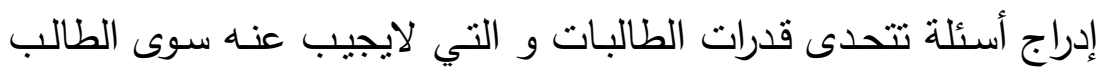

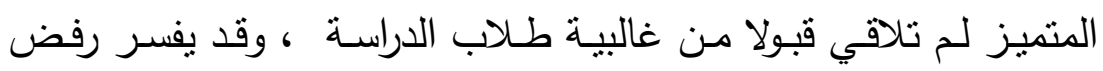

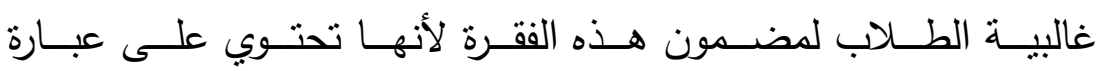
( سوى الطالب المتميز ) فقد يعتقد البعض منهم أن الأسئلة حتى وإن

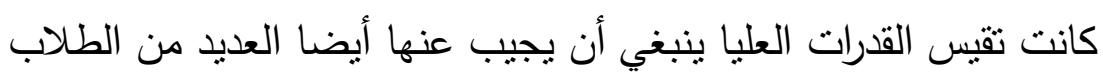
وليس الطالب المتميز فقط. ج-البعد الثالث (مجالات التقويم وأوزانها النسبية)

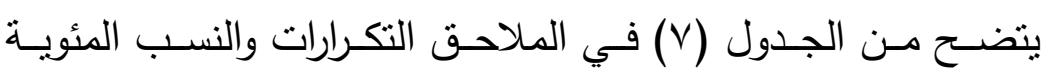
لاستجابات عينة الدراسة على فقرات البعد الثالث حيث حصلت الفقرة رقم

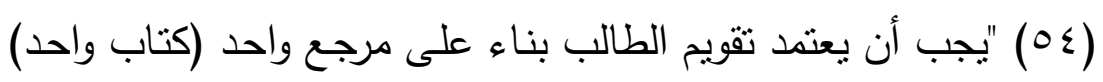

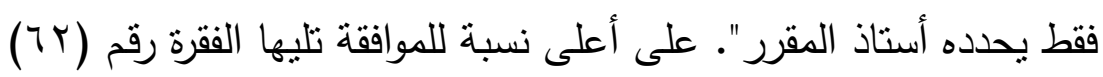

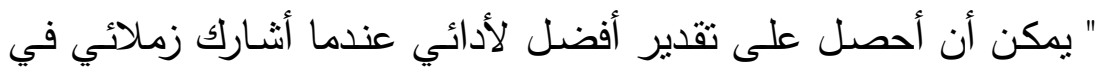

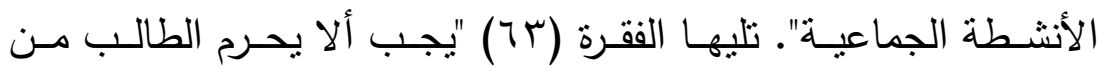

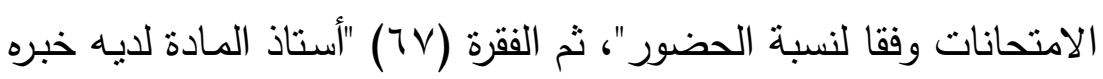


ودراية كافية بإمكانبات الطالب وقدراته وبالتالي يمكن أن يكون لـه الحرية في منح الطالب درجات تعويضية عند فقدانه تقديرا يستحقه" .ثم الفقرة

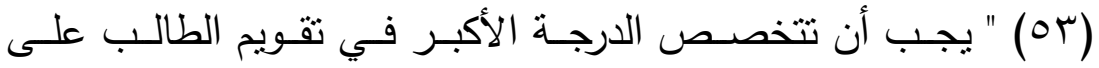

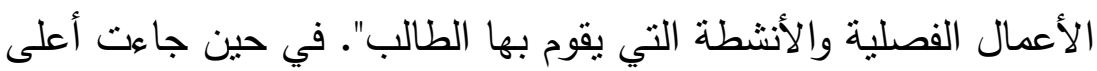

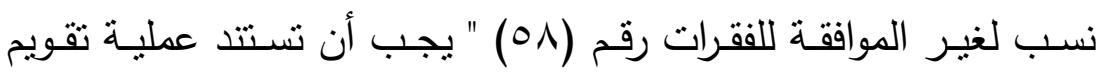

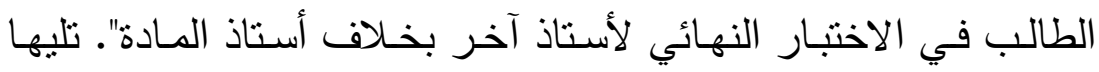

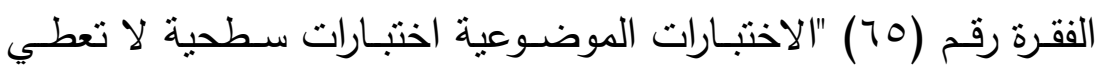
صورة حقيقية عن تمكن الطالب من النواحي التحصيلية". ويبدو مـن القائمسة المبينـة بجدول (r) بشكل عـام أن العينـة الكليـة

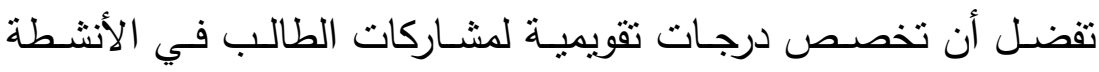
الجماعيـة والمشـاركات والمسابقات الخاصـة بها وعدم اقتصـار الدرجات التقويميـة على النواحي التحصيلية فقط بـل يجب أن يمتد إلى جوانب واتب

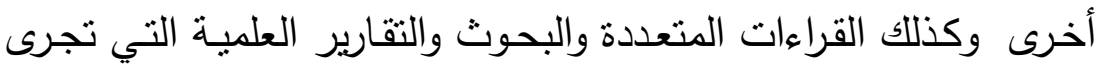

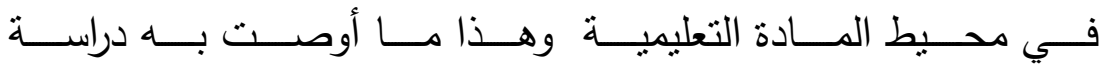
(Ocak \& Yildiz 2011) التي أثنارت إلى ضرورة التنوع في تقويم أداء

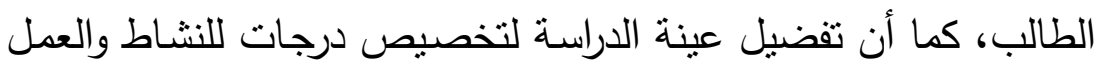
الجماعي نابعا من إدراكها لأن هذا النوع من الأنشطة لهـ أثنار أكثر

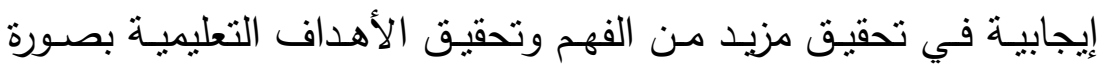

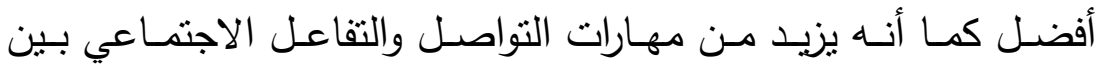

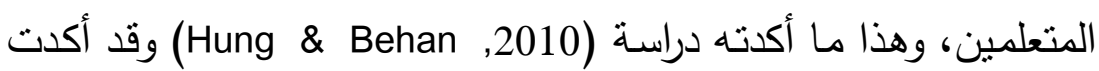

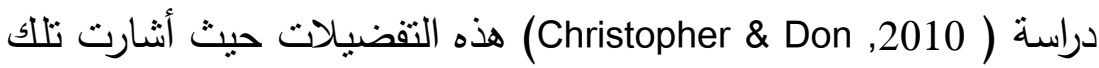
الدراسـة أن الجوانب التي يجب استهدافها من عمليات التقويم التكويني

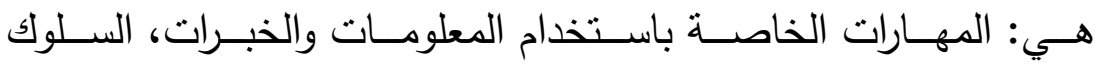
التعـاوني،التفكير الناقـد، التفكيـر التـاملي، مهـارات البحـث، مهـارات

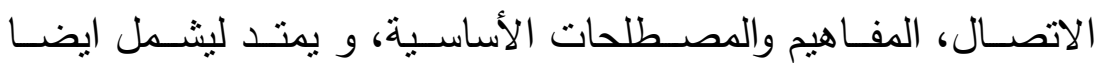


الجوانب الخلقية والتنظيمية والالتزام كما أن عدم الاقتصسار على الجوانب

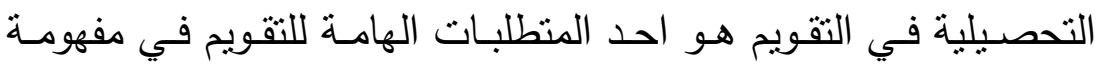

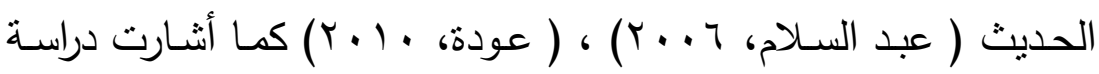

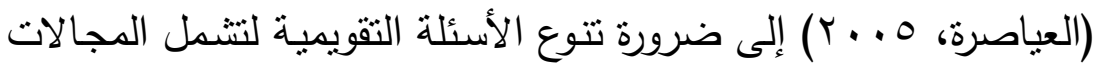

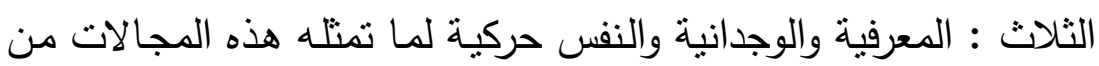
اهميـة في تحقيق أهداف التعليم وغاياته، كما اوصسى المؤتنمر العربي

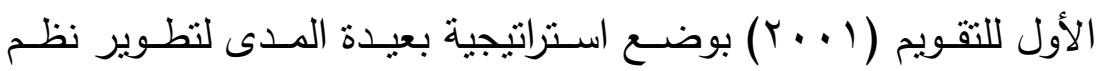

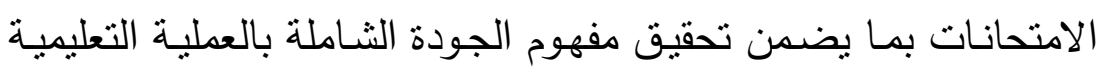

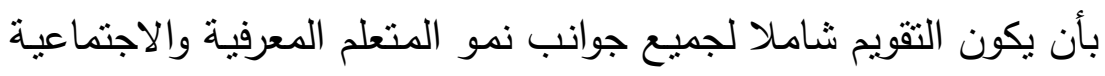
والوجدانية والخلقية.

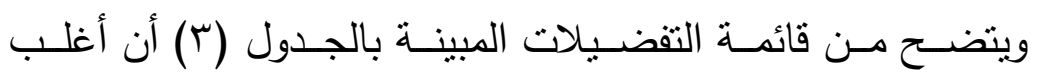

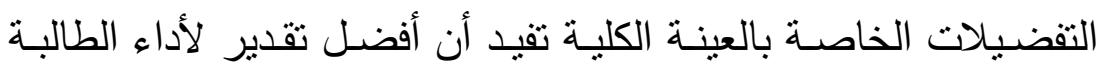

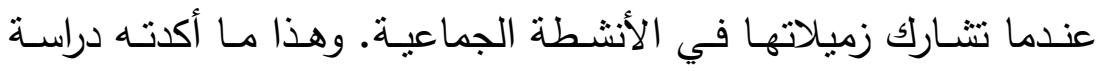
(Ozogul \& Sullivan ,2009)

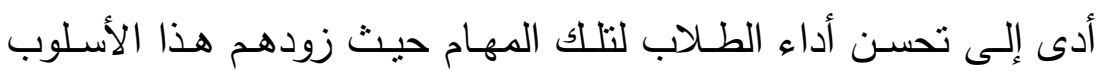

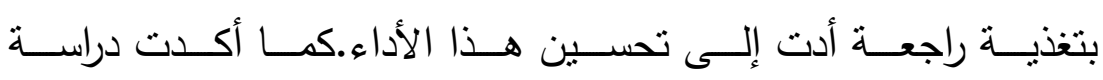
(Ocak \& Yildiz ,2011) أيضـا أفضلية هذا الأسلوب في تقويم أداء

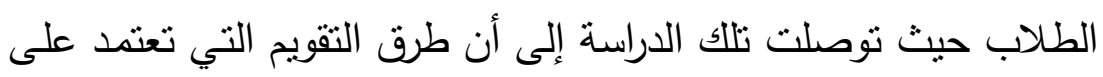
المهام الأدائية هي الأفضل وكذللك قياس ما تم إنجازه من أهداف تعليمية لتصنية تتعلق بمحتوى المقرر عند تتفيذ هذه الطرق في ظروف ومواقف معينة

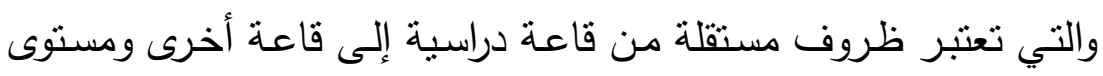
تحقق هذه الأهداف، وهي طرق تستخدم في أغراض التقويم التكويني

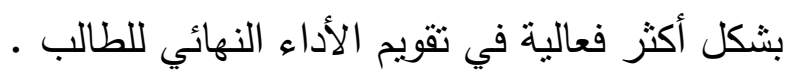

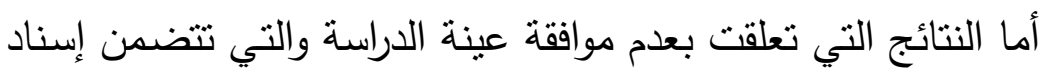

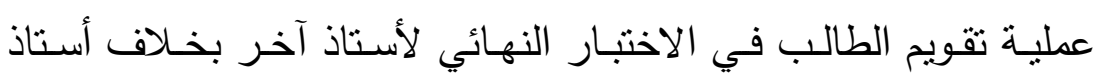


المادة، قد يفسر بأن الطالبات الجادات يبذلن جهدا ضخما في إنجازهن

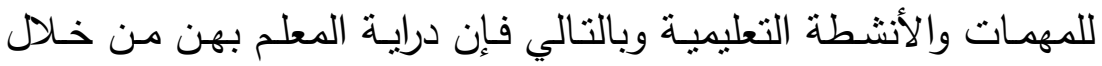

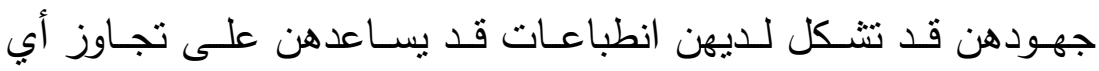
عثرات.

كما بدت أيضاً عدم موافقة الطالبات على أن الاختبارات الموضوعية اختبارات سطحية لا تعطي صورة حقيقية عن تمكن الطالب من النواحي التحصيلية.حيث بدا بشكل عام مما سبق وجود اتجاهات إيجابية لعينة

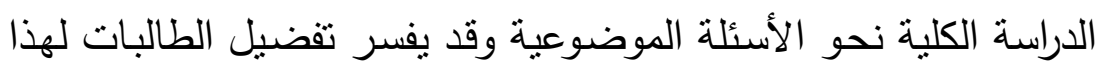

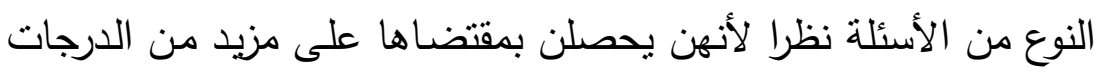

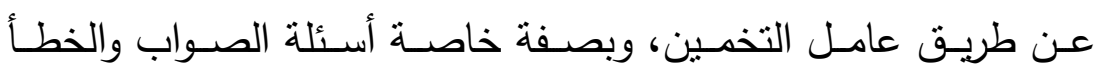

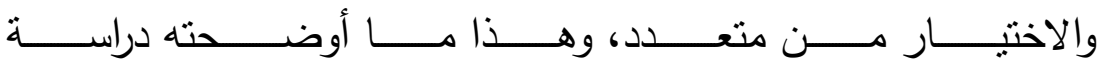
(Gellman \& Berkowitz, 2008)

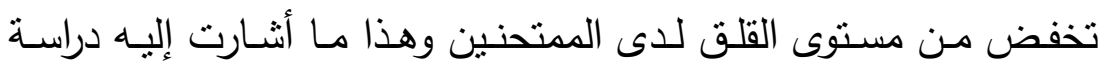
(Baeten et al.,2008). كما أن هذه النوعية من الأسئلة تغطي أغلب دئب

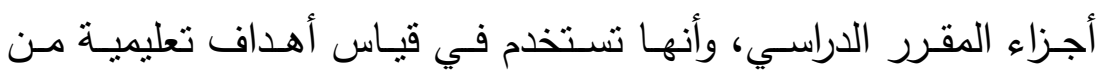

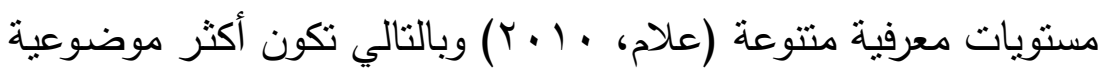

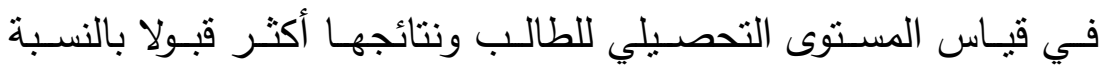
للمدحنن. د-البعد الرابع (التهيئة للتقويم): يتضـح من الجدول (^) التكرارات والنسب المئويـة لاستجابات عينة

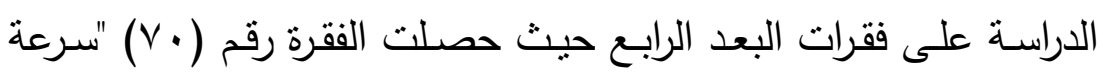

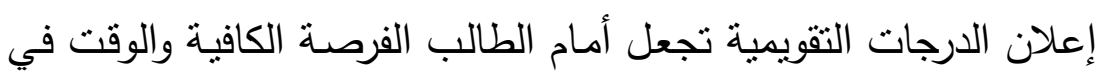
تعديل وتحسين مستواه" على أعلى نسبة للموافقة "، تليها الفقرة رقم (79)

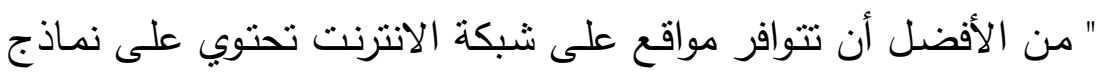

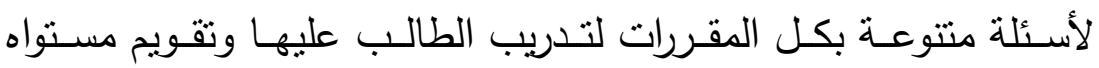


التحصيلي ذاتبا". تليها الفقرة (VV) "يجب أن يمنح الطالب مزيدا من

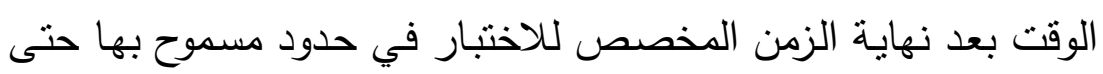

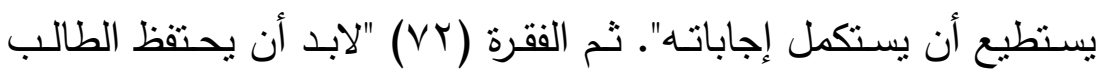

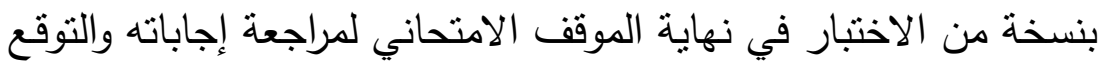
الدقيق للارجة التي يستحقها". ثم الفقرة (V) " القيود التي تقرضها النظم

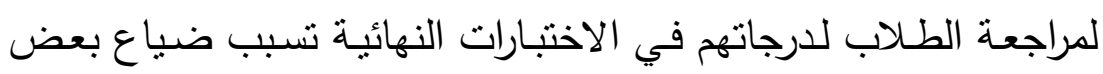
الدرجات التي يستحقونها". في حين جاءت أعلى نسب لغير الموافقة

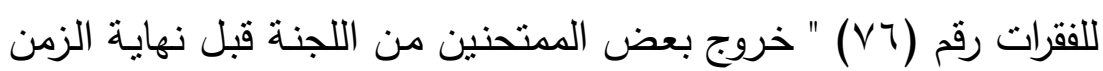
المخصص للاختبار يزيد من توتري وفقداني للتركيز اللازم للإجابـة".

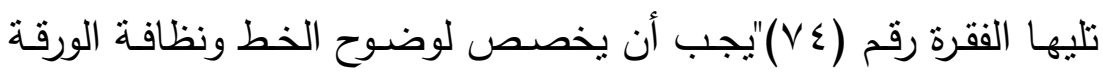
وحسن تتظيم الطالب للإجابة جزء من الدرجات".

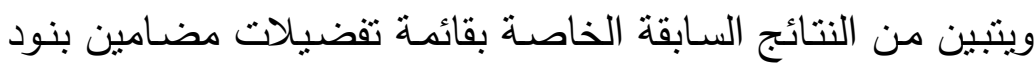
هذا الجانب الموافقة الثديدة للعينة الكلية على سرعة إعلان الدرجات التقويمية تجعل أمام الطالبة الفرصـة الكافية والوقت في تعديل وتحسين

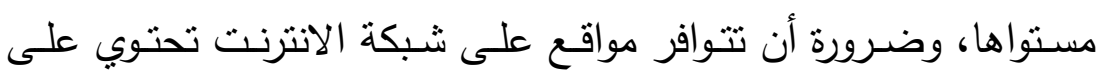

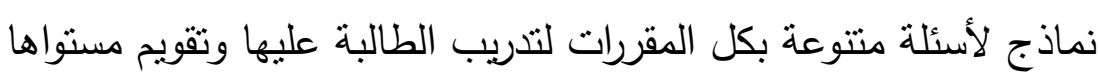

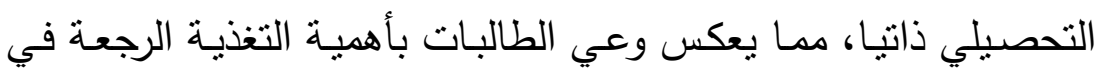
الكثَف عن الأخطاء وسـرعة علاجها ، كـا أن توافر نمـاذج لأسـئلة

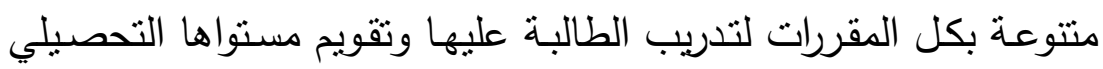
ذاتيا يشكل مرحلة هامة من مراحل التقويم التكويني فقد تبين من خلال الأدبيات أنها تؤدي إلى تحسين قدرة الاحتفاظ بالمفاهيم. وإعطاء التخذية ماتية

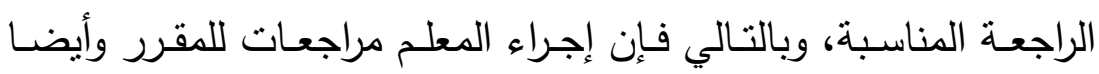

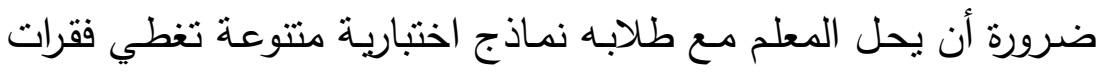

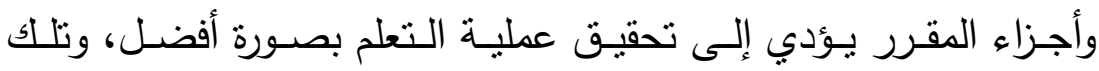

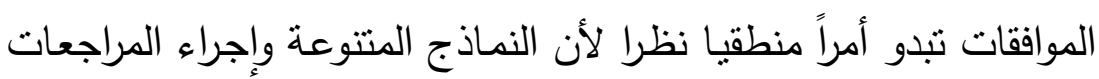


من شأنها أن تقدم التغذية الراجعة التي تفيد الطالب في إدراك أخطائه

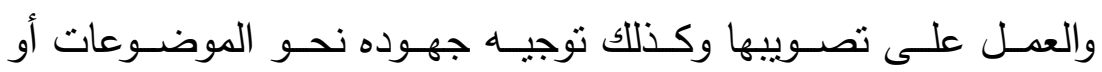
الأهداف التعليمية التي لم تتجز بعد بهدف السعي إلى إنجازها في الفترة

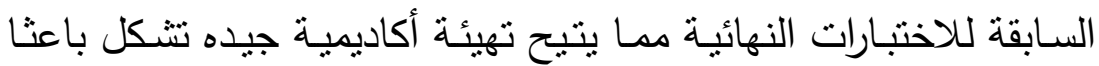
للاطمئنان والارتباح النفسي الذي يمكنه من الأداء الجيد في الاختبارات

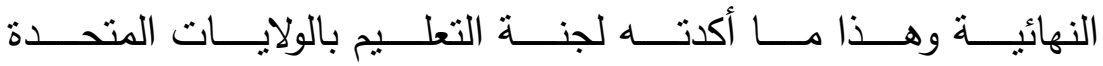
(EducationCommission of the States ,2010) (Michael \& Charles ,2010) أنتـار كلاهمـا إلى أن حصـول الطالب على التغذيـة الراجعـة في الفترة

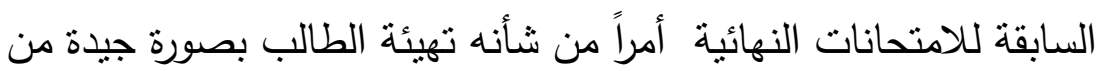

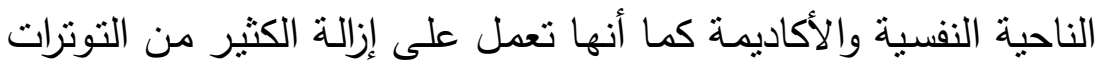

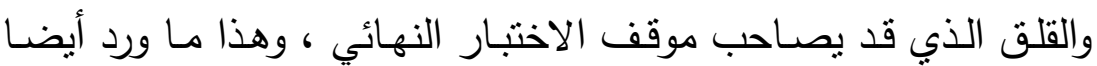
بدراسة( Jacqueline et.al., 2010 ). والتي أوضحت نتائجها أن إدرالك

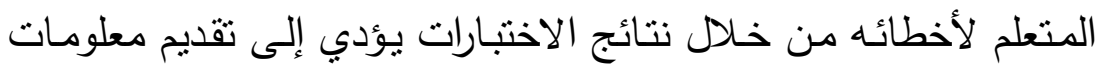
تفيده، وقد أكدت دراسة (Tang \& Harrison,2011) أن التغذية الراجعة المتمركزة حول الطالب والتي تهتم بتحديد أوجه الضعف ونواحي القصور

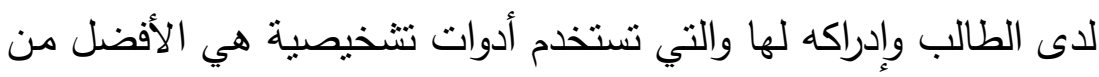
بين عدة طرق أخرى في تقديم التخذيـة الراجعة، يمكن أن تزود المعلم بدليل على نجاح الطالب في إنجاز المهام والممارسات التعليمية الخاصة

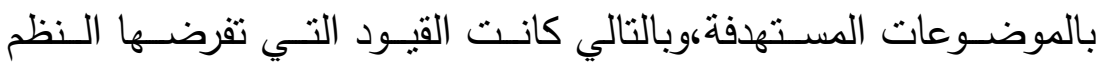

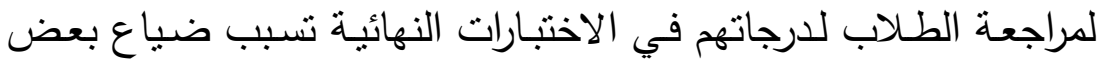
الدرجات التي بستحقونها. كما تبين أيضـا من قائمسة التفضيلات عدم موافقة العينة الكلية على أن خروج بعض الممتحنين من اللجنة قبل نهاية الزمن المخصص للاختبار يزيد من التوتز ويؤدي إلى فقدان التركيز الـازم للإجابة.قد يفسر بـأن 
الاستعداد الجيد للاختبـارات وقدرات الطالب الفعلية لا تتأثر بمثل هذه المواقف.

هـ - البعد الخامس (نظم الامتحانات وإلمراقبة)

يتضـح من الجدول (9) التكرارات والنسب المئويـة لاستجابات عينـة

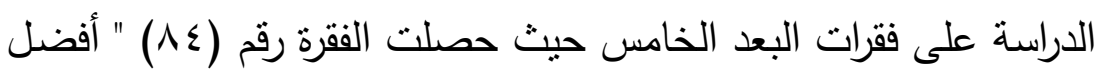

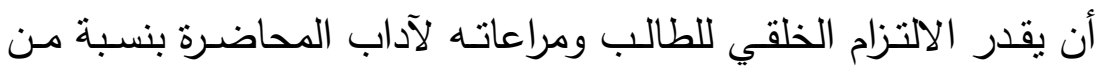

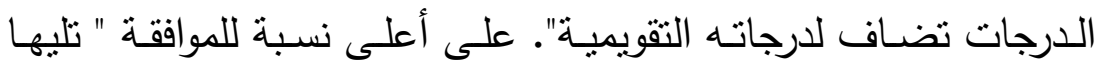

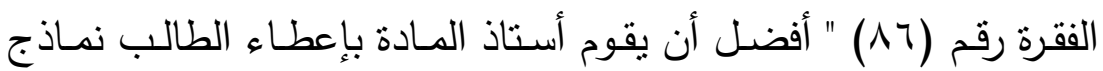
اختباريـة متتوعـة تغطي جميع فقرات وأجزاء المقرر يـأتي منهـا أسـئلة

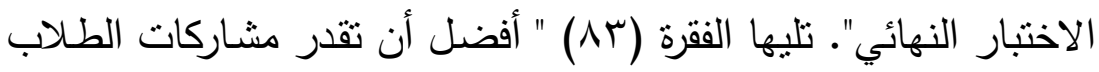

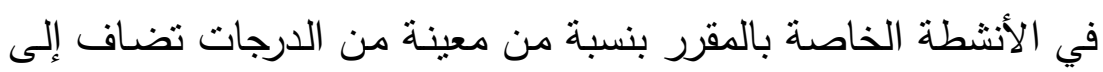

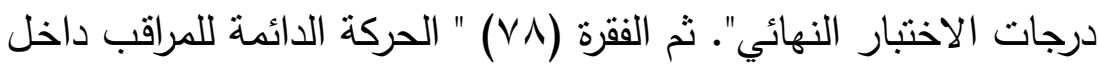

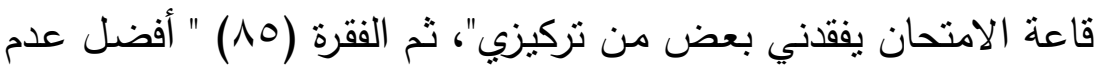
إعادة تقويم الطالب في نفس موضوعات المقرر والتي سبق تقويمه بها من قبل ". في حين جاءت أعلى نسب لغير الموافقة للفقرات رقم (^^) " أفضـل أن يقوم أداء الطالب في نهايـة كل محاضـرة" تليهـا الفقرة رقم (^9)"أفضل أن يقوم أداء الطالب في نهاية كل وحدة دراسية." يبدو من النتائج المتعلقة بالجدول (0) أن مضامين البنود التي حققت

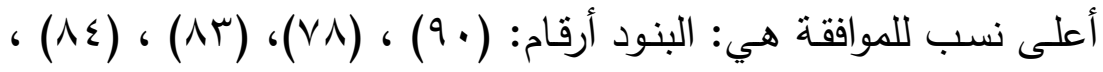

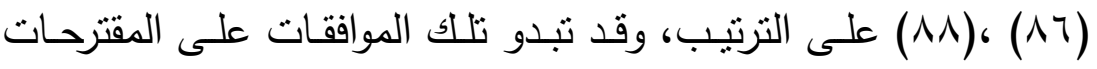
التقويميـة المتضمنة بتلك منطقيـة إلى حد مـا حيث أن الحركـة الدائمـة

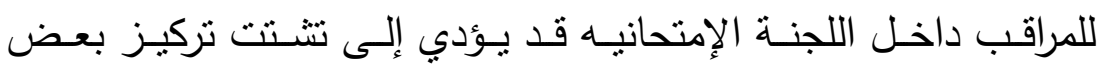

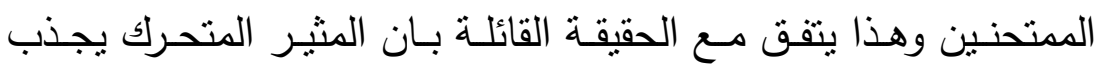

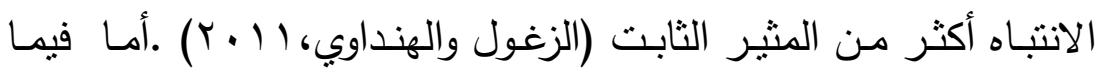
يتعلق بتخصيص درجات في تقويم الجانب الخلقي للطالب، الذي يتعلق 
بآداب المحاضرة قد يعود إلى أن الجانب الأخلاقي على درجة عالية من

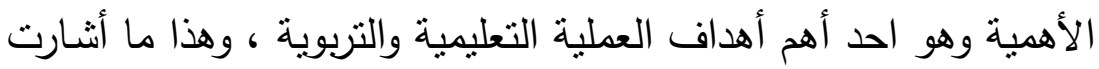

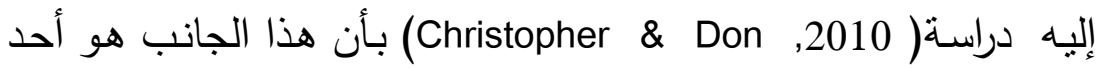
الجوانب العديدة المستهدفة تقويميا وبالتالي ينبخي ألا يخصص له درجات

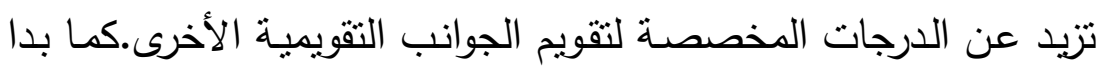

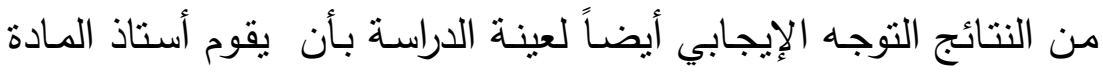

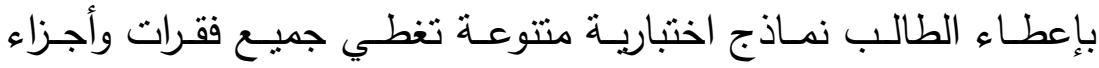

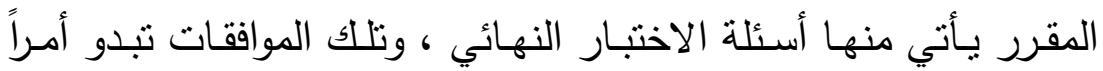

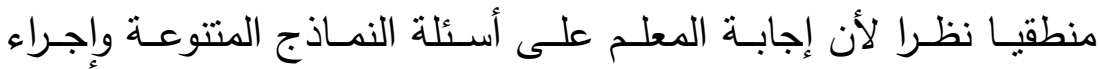
المراجعات من شأنها أن ثقدم التغذية الراجعة التي تقيد الطالب في إدراك

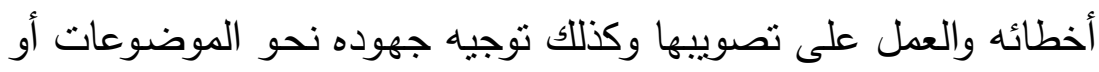
الأهداف التعليمية التي لم تتجز بعد بهدف السعي إلى إنجازها في الفترة

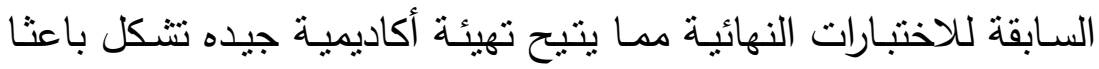
للاطمئنان والارتياح النفسي الذي يمكنه من الأداء الجيد في الاختبارات

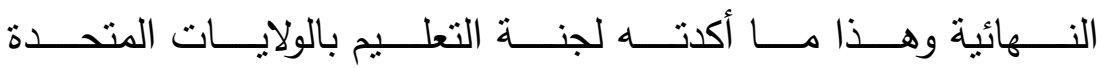
(Education Commission of the States ,2010) (Michael \& Charles ,2010) وأيضا دراسة) (Hamilton, 2011 ) ويث أنتـار كلاهمـا إلى أن حصـول الطالب على التغذيـة الراجعـة في الفترة

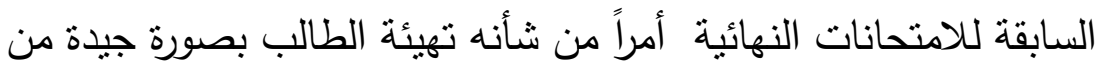

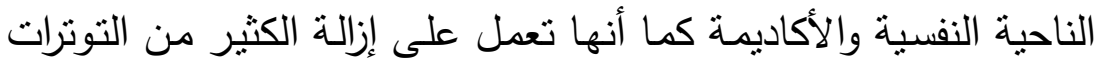

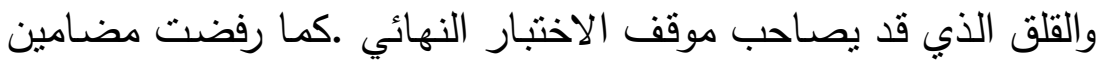

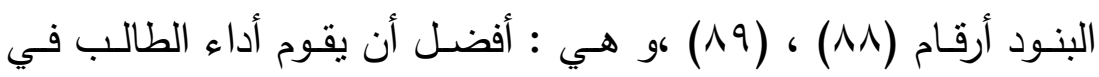

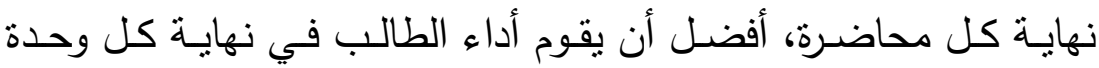
دراسية. والتي قد تفسر بأن الطلاب منقلين بالأعباء الدراسية والتكليفات

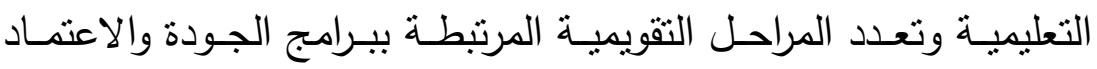


الأكاديمي مما قد يكون شكل اتجاهـا لديهم رافضـاً لتعدد وكثرة المراحل التقويمية في نهاية كل محاضرة أو نهاية كل وحدة دراسية. ثانياً: نتائج إجراءات الإجابة عن السؤال الثاني من تساؤلات الاراسة

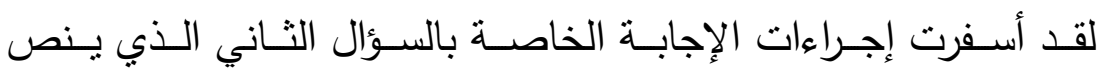

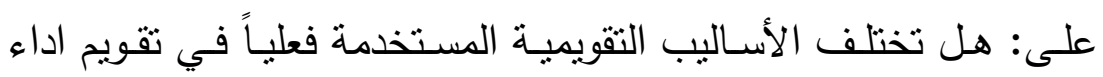

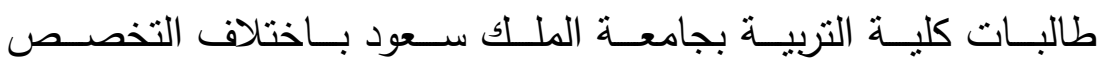
(علم نفس-نربية خاصة كرياض اطفال- ثقافة اسلامية- تربية فنية)؟

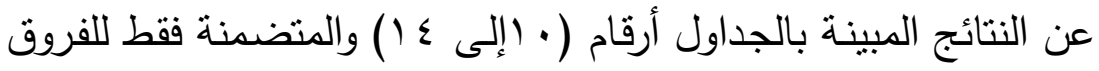

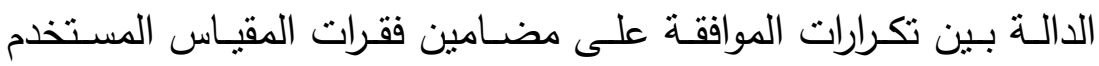

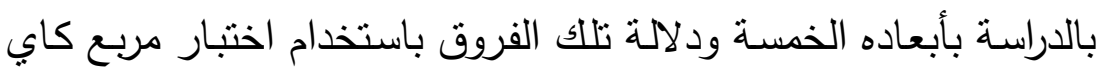

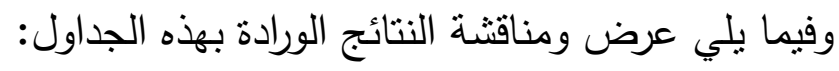

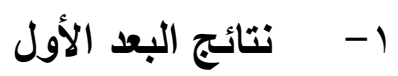

لقد أظهـرت النتـائج الـواردة بالجـدول(· • () وجـود فـروق دالـة بـين

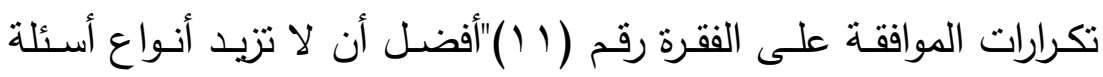

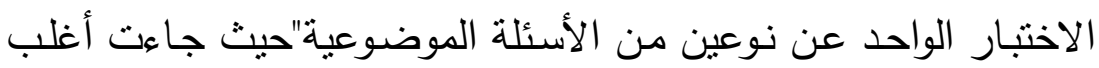

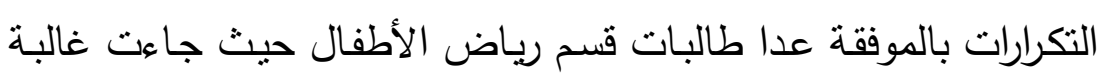

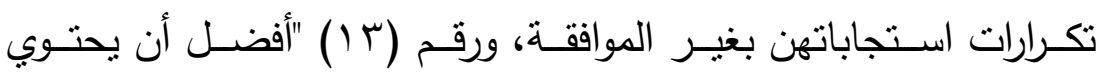
الاختبار الواحد على خليط من الأسئلة الموضوعية والمقالية" في صالح

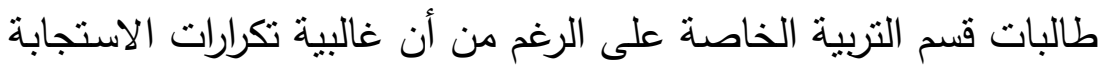

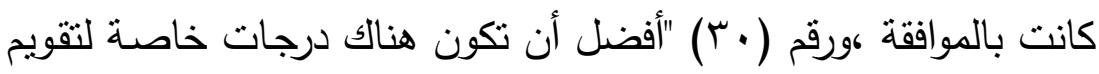
الطالب تعطي للانضباط داخل المحاضرة والالتزام بالسلوك الأخلاقي"

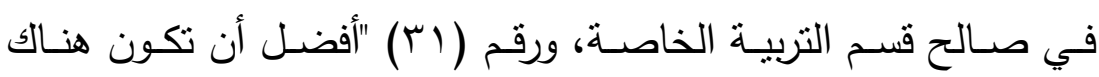
درجات خاصـة لتقويم الطالب تعطي لنسبة الحضور " في صـالح التربية

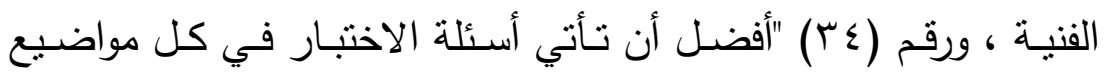

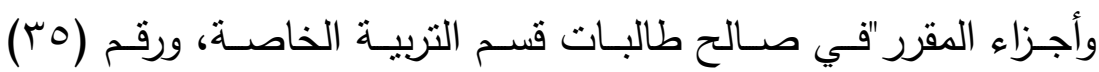


"الاختبارات الموضوعية أفضل من الاختبارات المقالية في إبراز مواهب

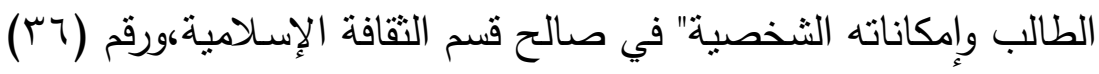

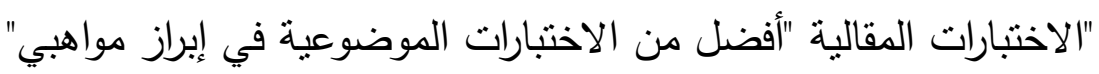
وإمكانيتي الثخصية.في صالح قسم التربية الفنية. r لقد اتضـح من النتائج الواردة بالجدول (1 (1) أن العبارات الدالـة في

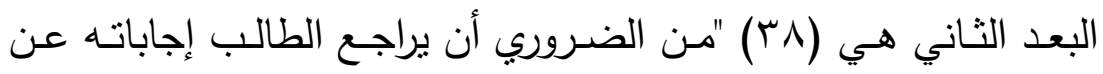

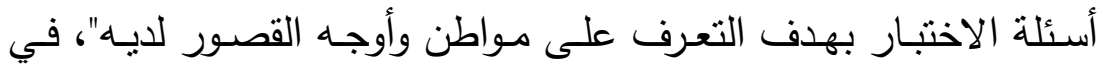
صالح قسم رياض الأطفال، ورقم (1) "يجب أن يحتوي الاختبار على معلى

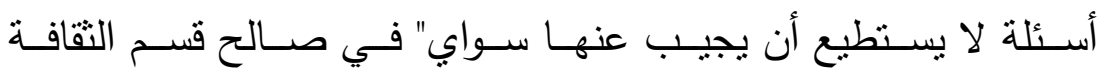

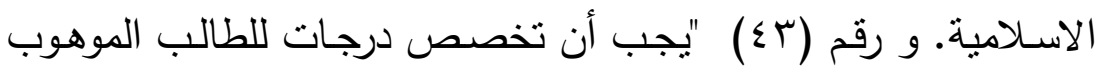

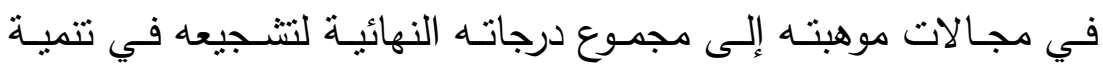

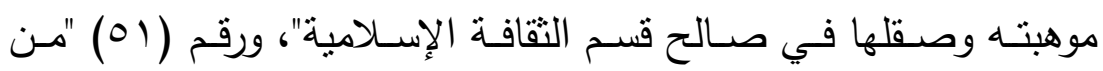
الضروري أن يجيب أستاذ المادة على أسئلة اختبارات الأعمال الفصلية لتعريف الطلاب بأخطائهم وتوجيههر"في صالح قسم الثقافة الاسلادية.

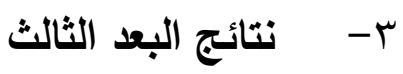
وأما فيما يتعلق بالبعد الثالث فكانت العبارات الدالة هي أرقام (ع نه) "يجب أن يعتمد تقويم الطالب بناء على مرجع واحد (كتاب واحد فقط)

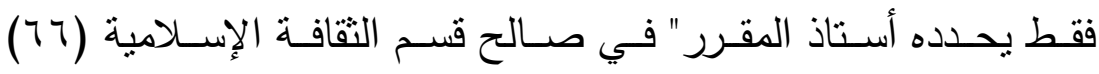

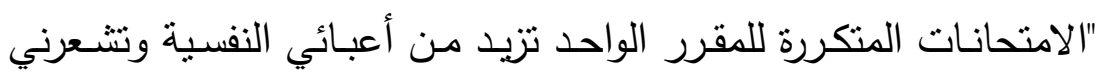

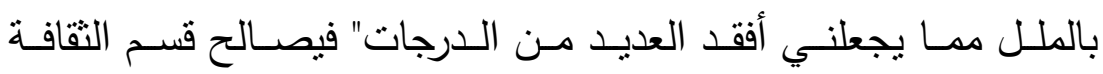
الإسلامية أيضاً.

ع - - متائج البعد الرابع

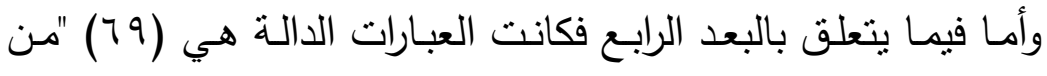
الأفضل أن تتوافر مواقع على شبكة الأنترنت تحتوي على نماذج لأسئلة 
متتوعة بكل المقررات لتدريب الطالب عليها وتقويم مسنتواه التحصيلي

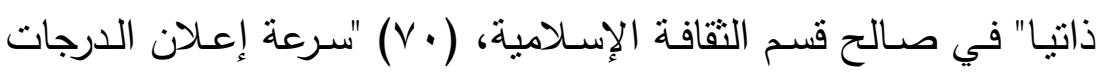
التقويمية تجعل أمام الطالب الفرصة الكافية والوقت في تعديل وتحسين مستواه" في صالح قسم الثقافة الإسلامية. - - - متائج البعد الخامس أما فيما يتعلق بالبعد الخامس فكانت العبارات الدالة هي رقم (V^)

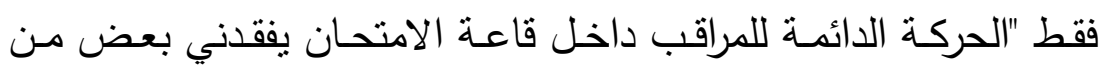
تركيزي".

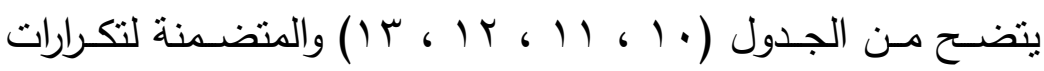

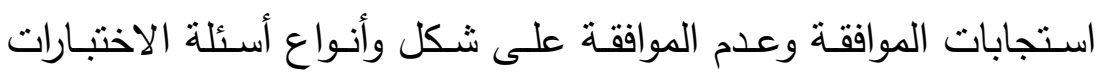
التحصيلية لعينات المقارنة التي تختلف باختلاف انتسابها لأقسام الكلية،

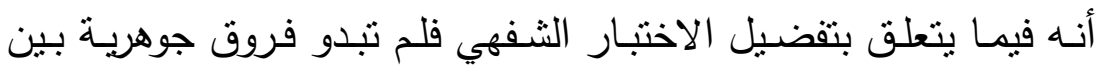

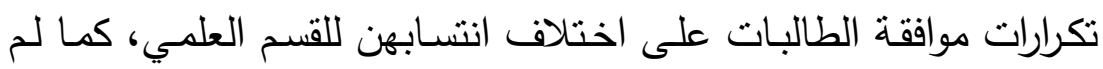

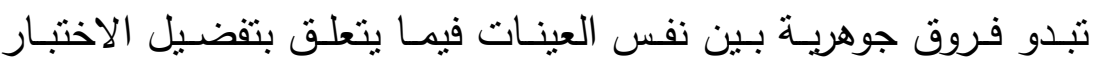

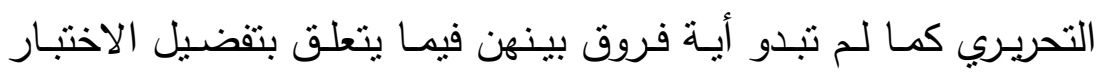

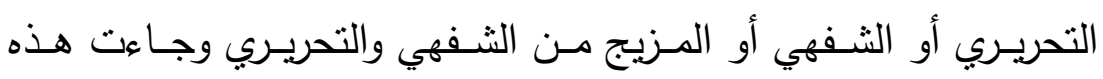

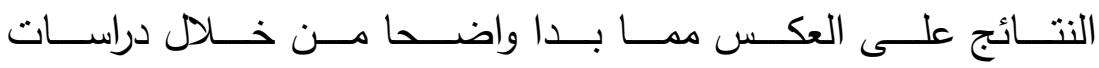
(Ben-Chaim \& Zoller ,1997), (Birenbaum \& Feldman ,1998), ) (Beller \& Gafni 2000),( Traub \& McRury ,2010) ) والتي توصلت إلى أن تفضيلات الاختبارات التحريرية لطلاب الجامعة تفوق تفضيلاتهم

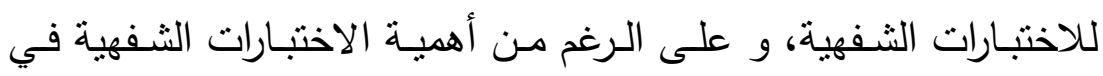

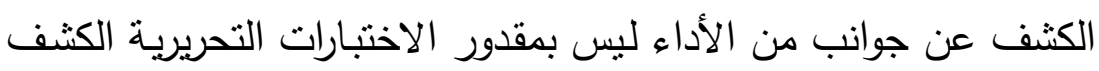

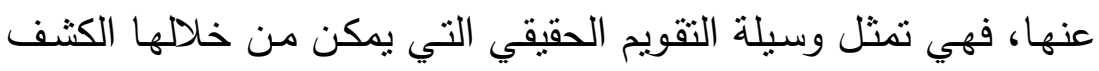

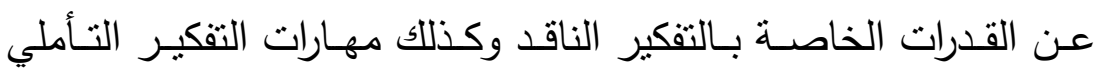

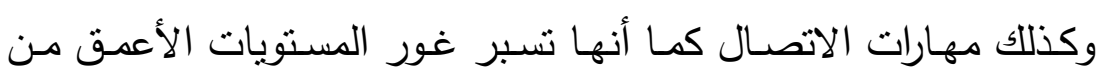


الفهم وهذا مـا أكدته دراسـة (James, 2011)، وهذه الاختبـارات يقل

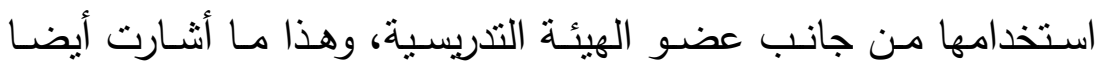

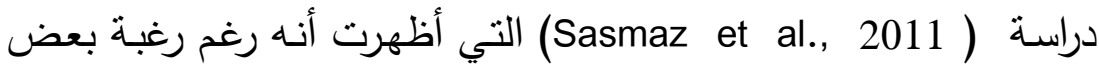
طـلاب الجامعـة المعلمـين قبـل التخـرج لاسـتخدام الاختبـارات الثـفهية

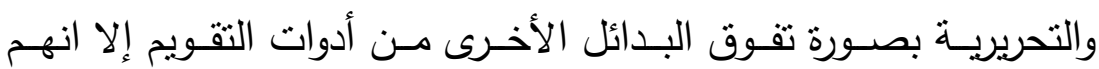
يعتقدون انهح سوف يواجهم مشاكل عند استخدامها وبصفة خاصة عند

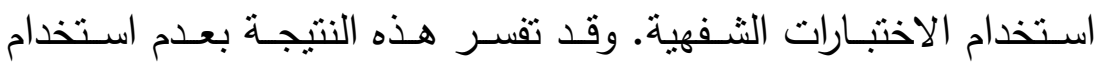
الاختبارات الثفهية في إجراءات تقويم أداء الطالب في مختلف الأقسام العلمية بالكلية وبالتالي تفتقر الطالبات للخبرة الكافية للحكم الموضوعي التهاءي على هذه النوعية من الاختبارات.كما تفسر أيضاً هذه النتيجة إلى كثرة

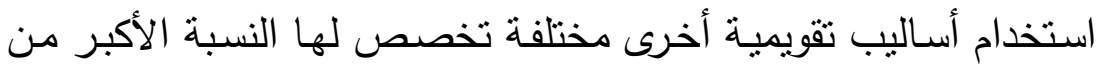
الدرجات التقويميـة الخاصـة بـالمقرر ، ومـن بين هذه الأسـاليب التقويميـة

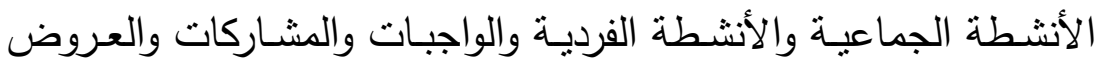
والتقارير • ممـا ادى إلى عدم وجود فروق جوهريـة بين تكرارات الموافقة

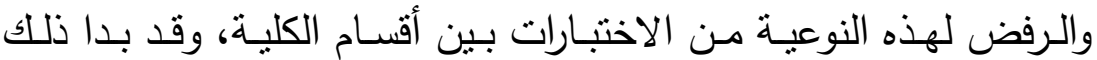
متناقضا مـع ما أنثارت إليه دراسات ( (1997, Ben-Chaim \& Zoller) (Birenbaum \& Feldman ,1998), (Beller \& Gafni 2000) ,

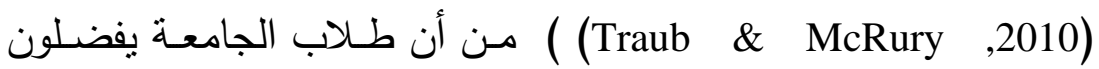
الاختبارات التحريرية عن تفضيلاتهم للاختبارات الثفهية، وقد تفسر هذه النتيجة بأن طلاب الجامعات الغربية وبصفة خاصة طلاب البكالوريوس

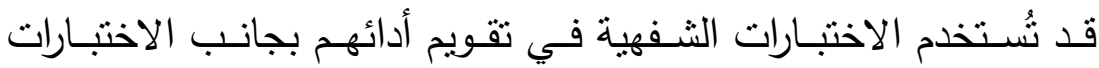
التحريريـة، مدـا يجعلهم فـي مواقف مقارنــة بـين هـذين النـوعين مـن الاختبارات يستطيعون من خلالها بناء رؤيتهم التقويمية على أسس أكثر هورين

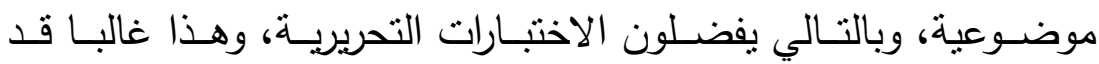
لايحدث في تقويم أداء طلاب البكالوريوس في أغلب الجامعات والكليات 
العربية حيث يعتمد فيها على الاختبارات التحريريـة وبالتالي لاتستطيع

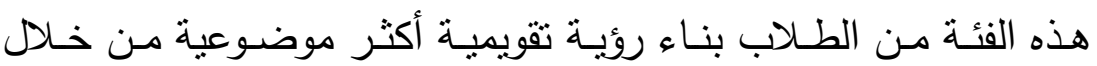
مواقف مقارنة بين هذين النوعين من الاختبارات.

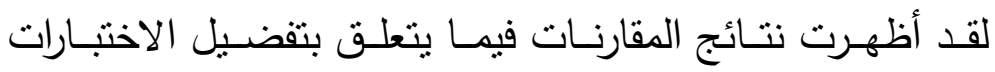

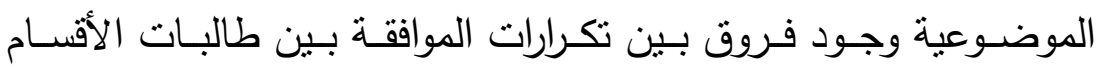

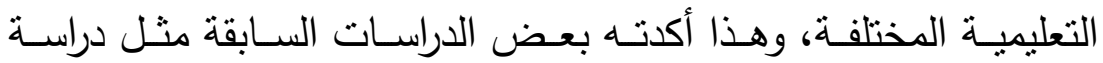

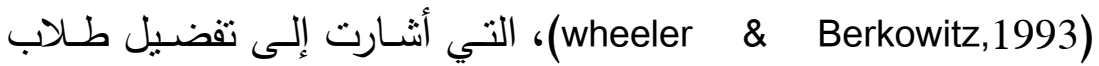

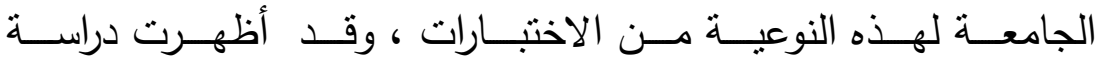

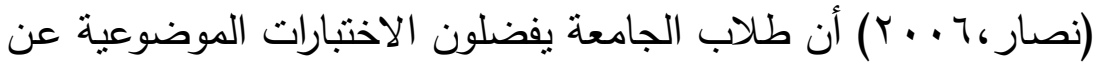
المقاليــة، كمــا توصــلت بعـض الدراســات الأخـرى مثتـل دراســات (Birenbaum \& Feldman,1998) ,(Beller \& Gafni 2000),)

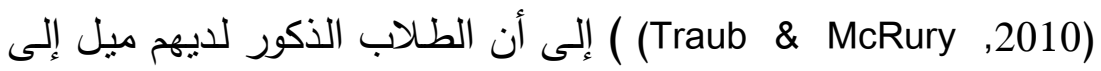

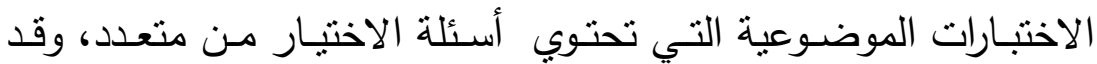
يرجع أسباب ذلك أنها تخفض من مستوى القلق لدى الممتحنين وهذا ما أنشارت إليه دراسة (Baeten et al.,2008) التي أكدت أن الطلاب الذين يعانون من مستوى مرتفع من القلق يفضلون الاختبار المتضمن لأسئلة

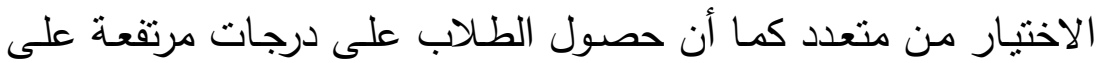

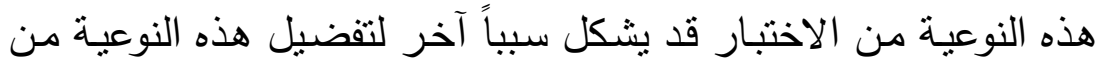

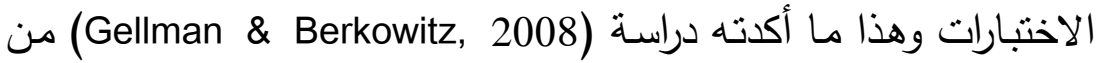
أن درجات الطلاب والطالبات على أسئلة الاختيار من متعدد أعلى من النا درجاتهم التي يحصلون عليها في الاختبارات التي تحتوي على أسئلة من

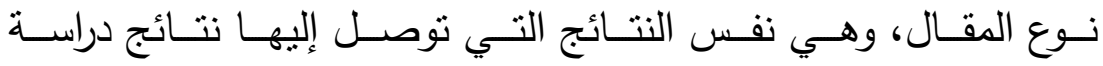

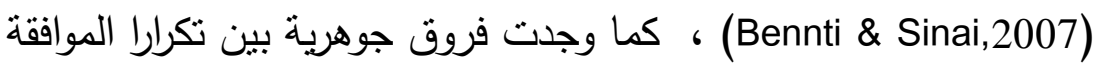

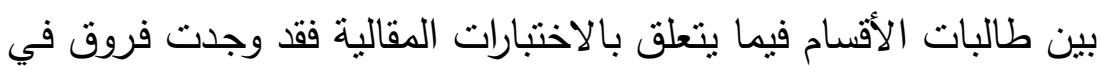
صالح قسم التربية الفنية، كما وجدت فروق جوهرية بين طالبات الأقسام 


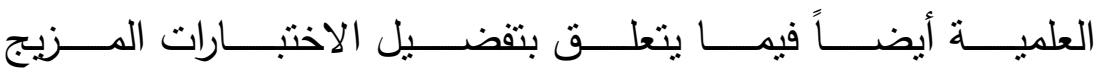
( موضـوعي + مقـالي ) ، وقـد يعـى هذا الأمـر إلى طبيعـة المقررات الدراسية للتربية الفنية التي يكون تقييمها باستخدام الأسئلة المقالية أقرب مـن اسـتخدام الأسـئلة الموضـوعية ، وقد تفسـر هـذه النتيجـة بالطبيعـة الخاصة لهذه البنود التي يمكن خلالها إبراز القدرات الإبداعية والمهارات العليا وهي أقرب لمقررات التربية الفنية التي يبلغ عليها الجانب الإبداعي عن مقررات الأقسام الأخرى كما تبرز كذللك فردية الممتحن في المجال

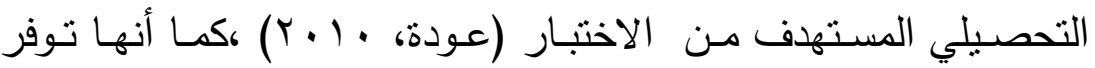

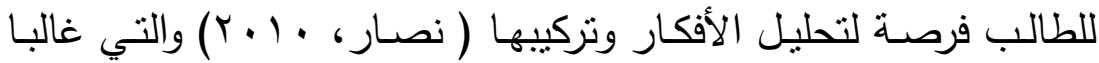
يتمتهـع بهـا طـالاب الدراســات العليـا كطـلاب متميـزين مـن الناحيـة التحصيلية، يلي ذلك منتسط طلاب البكالوريوس وقد يفسر ذلك بان هذه النوعيـة مـن الأسـئلة لا ثتيح لطالب البكالوريوس فرصـة التخمين على

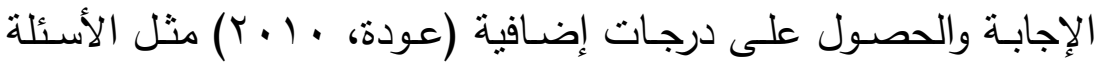
الموضـوعية، كمـا أنها تتطلب في معظم الإجابـات الخاصـة بهـا إجابـة مطولـة تسـتغرق وقتا أطـول كمـا تطلب أحيانـا الإجابـات الخاصـة بهـا توظيف بعض القدرات العقلية العليا (المرجع السـابق، ا • ب) التي قد يفتقر إلبها بعض الطلاب كما أنها تشمل عدد محدود من نقاط المنهج ولاتغطي المقرر بأكمله ( نصار ، · ( • (Y)، كما أنها تتأثز بذاتيـة مقدر الإجابة على نحو كبير (عودة، • ( • (Y). وقد اكدته بعض الدراسات عدم تفضـيل طـلاب البكـالوربوس لهذه النوعيـة مـن الأســلة وهـي دراسـات wheeler\&Berkowitz,1993),(Birenbaum \& Feldman ,1998))

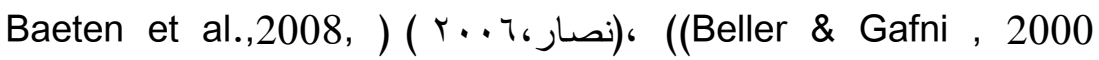
.((Traub \&McRury ,2010 
ثالثاً: عـرض ومناقثــة النتـائج الخاصـة بـإجراءات الإجابـة الخاصـة بالسؤال الثالث:

لقد أسفرت إجراءات الإجابـة الخاصـة بالسؤال الثالت الذي ينص على: "هل تختلف الأسـاليب التقويميـة المستخدمة فعلياً في تقويم أداء طالبـات كليـة التربيـة بجامعـة الملـك سـود بـاختلاف المستوى الدراسـي

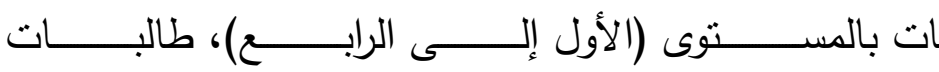

(المستوى الخامس إلى السابع)؟ " عن النتائج المبينة بالجدول رقم (10) وكانت العبارات الدالـة في البعد الأول هي رقم (ب) "أفضل أسئلة الفئل

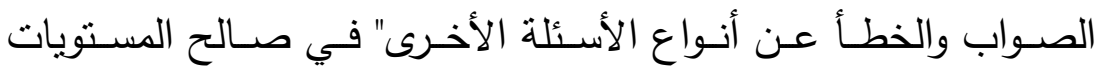

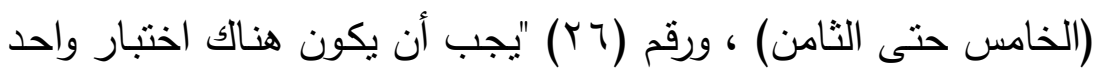

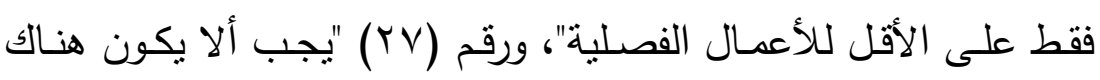
اختبارات للأعمال الفصلية ويكون تقويم الطالب للاختبار النهائي فقط". فقد جاءت النسب المرتفعة لاستجابة عدم الموافقة حيث لم يوافق ماورد بمضمونه طالبـات جميع المستويات وكانت أعلى نسبة لعدم الموافقـة للمستوى الخامس حتى الثامن وجاءت بشكل دال عن نسبة غير الموافقة

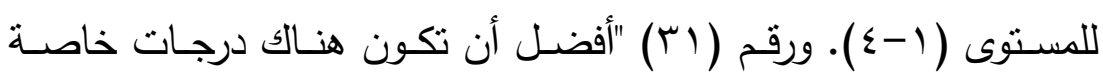
لتقويم الطالب تعطي لنسبة الحضور" حيث جاءت الاستجابات بالموافقة

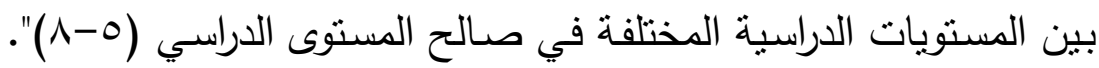

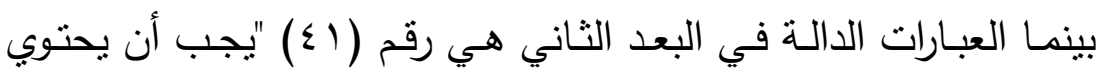
الاختبار على أسئلة لا يستطيع أن يجيب عنها سواي". جاءت بالموافقة

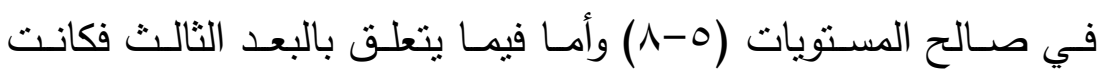
العبارات الدالة هي رقم (ع §) "أفضل أن بعلم زمـلاء الطالب بالدرجات

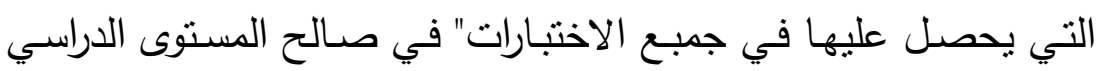
(1-0). ورقم (09) "يجب ألا ينفرد أستاذ المادة بتصحيح جميع أسئلة

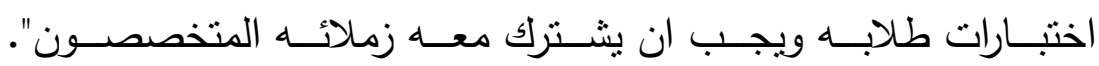


حيث جاءت أعلى نسب الاستجابة بعدم الموافقة في صسالح المستوى

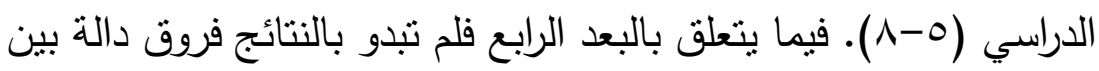

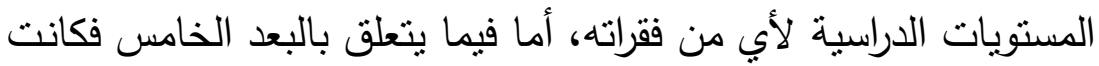

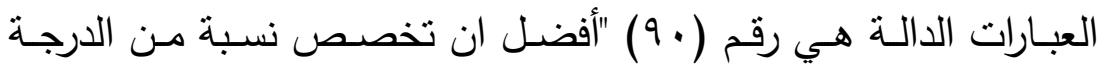

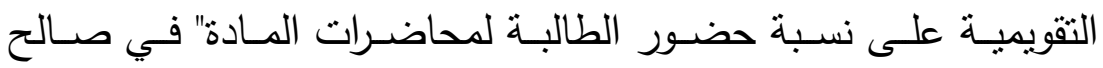
المستوى الدراسي (-0-1).

كما تبين من النتائج عدم وجودفروق جوهرية في تكرارات الموافقة

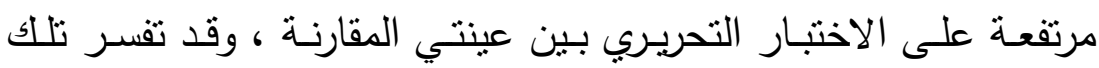

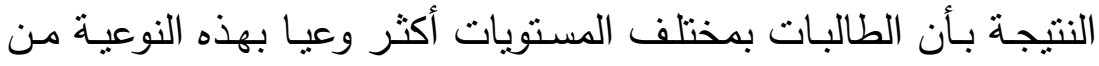

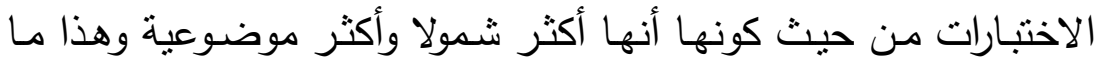

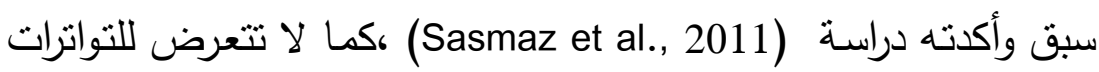

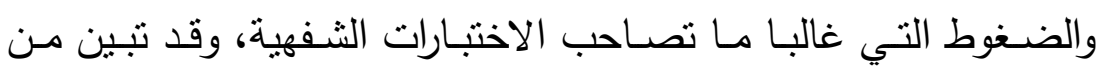
خلال النتائج السابقة عدم وجود فروق جوهرية بين نفس العينتين لكل من نـوعي الاختبـارات الموضـوعية والمقاليـة حيـث تبـين ان نسب المرتفعـة

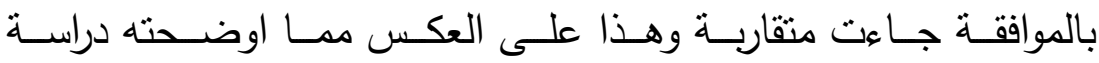
(Gellman \& Berkowitz, 2008) المستويات الدراسية الأعلى يفضلون الاختبارات الموضوعية نظراً لأنها

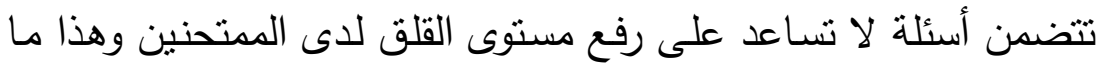

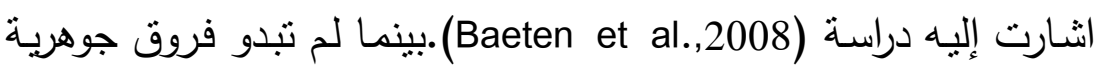

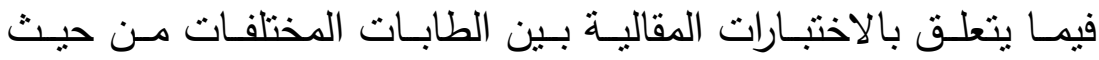

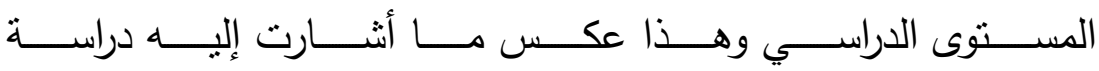

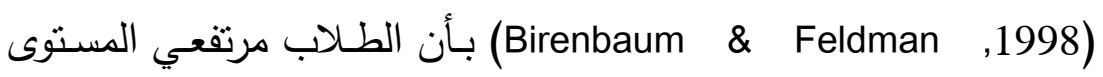
الدراسي يفضلون الاختبارات المقالية، وقد نبين كذللك من نفس الجدول السابق عدم وجود فروق جوهرية بين عينتي المقارنة فيما يتعلق بالموافقة على مقترح الاختبار المزيج من ( الموضوعي + المقالي ) وقد تفسر هذه بهن بانه 
النتيجة بوعي الطالبات على مختلف مستوياتهن الدراسية بأهية أنواع

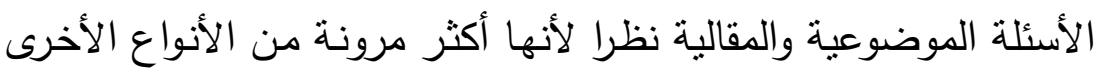
نظرا لإمكان استخدامها لقياس مدى تحقق أهداف تعليمية من مستويات

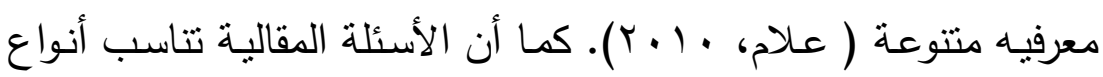
مهمـة في التحصـيل والتـي تمثنل مجـال واسـع مـن القدرات والمهـارات

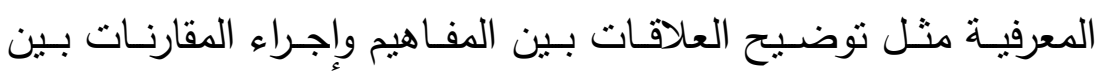
الظواهر وتطبيق القواعد والمبادئ وحل المسائل ونقد الأحداث وصياغة

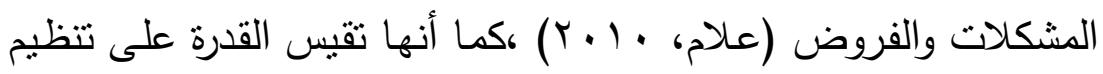

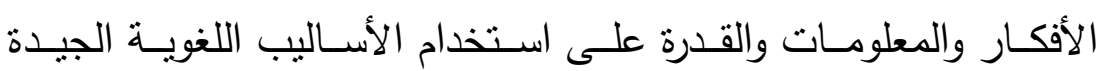
( نصار ، · ( + )، وهذا يعني أن هذين النوعين من الاختبارات يساهمان

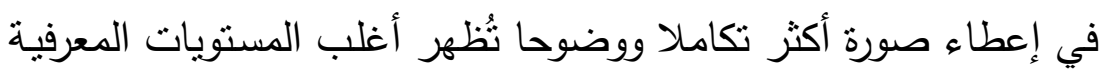

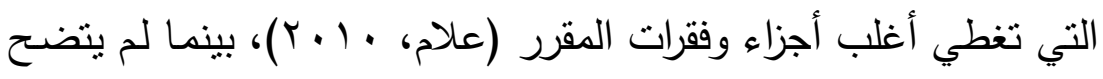
وجود فروق جوهريـة بين عينتي المقارنـة فيمـا يتعلق بالرؤيـة التقويميـة

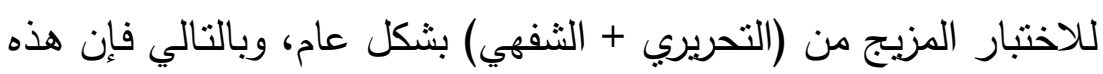

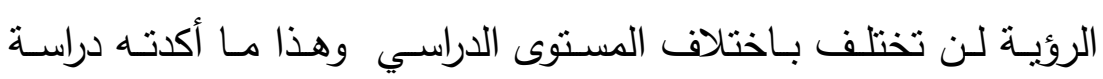
(Birenbaum \& Feldman , 1998) من أن روئية الطلاب للاختبارات

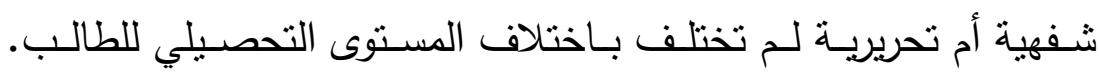
وقد جاءت كل العبارات الدالة المبينـة بالجدول رقم (10) في صـالح

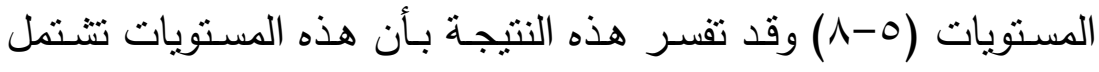

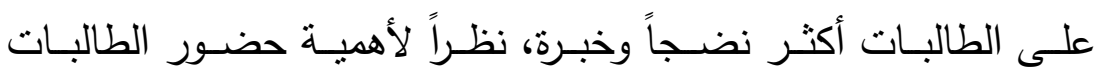

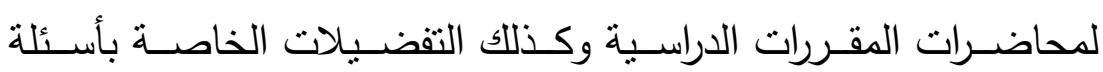
الصواب والخطأ قد تفسر بوعي تللك العينة بأن هذه النوعية من الأسئلة

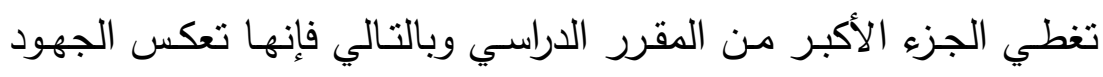

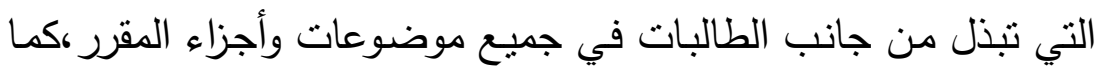
أن إعلان الدرجات التي يحصلن عليها الطالبات ومعرفة زمبلاتهن بهات بهات 
قد يؤدي إلى زيادة دافعية الطالبـات في بذل مزيد من الجهد وبالتالي

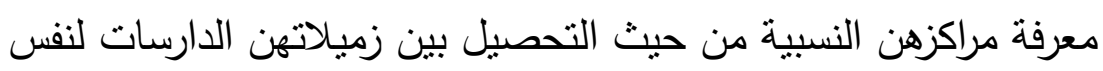
المقررات. رابعـاً: عـرض ومناقشــة النتـائج الخاصـة بـإجراءات الإجابـة الخاصـة بالسؤال الرابع.

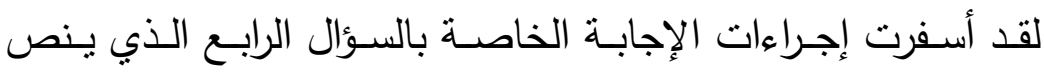

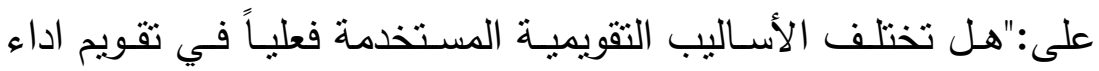
طالبـات كليـة التربيـة بجامعـة الملـك سـود بـاختلاف المعدل الدراسي (منخفض -متوسط -مرتفع)" عن النتائج المبينة في جدول رقم (7 ( ) وكانت كالتالي : لقد وجدت فروقاً دالة بين نكرارات الموافقة وعدم الموافقة على بعض وكل فقرات البعد الأول وهي الفقرات: رقم (r) "أفضل أسئلة الصواب والخطأ

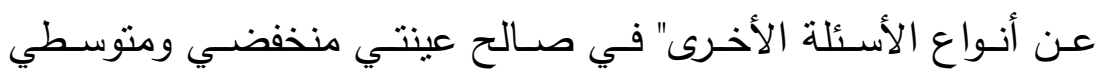
المعدل التراكمي. ورقم (0) "أفضـل أسئلة المزاوجـة عن أنواع الأسئلة الأسئة

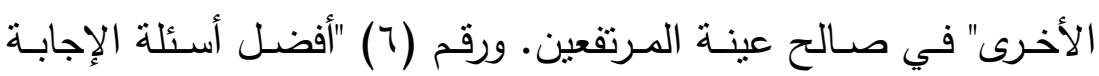

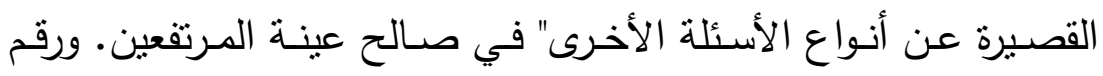
( • (1) "أفضل أن يحتوي الاختبار الواحد على نوعية واحدة من الأسئلة

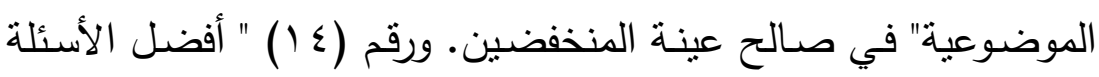
التي لا تستغرق وقتا طويلا أوتفكير عميقا للإجابة عنها" في صالح عينة

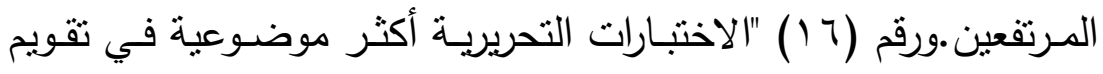
الطالب من الاختبارات الثفهية" في صالح عينة المرتفعين. ورقم (1)

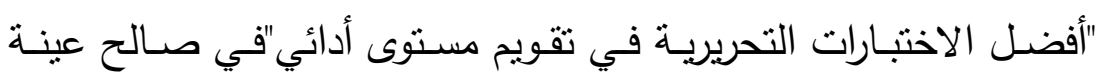
المرتفعين. ورقم (·r) "أحب أن تخصص الدرجة الأكبر من تقييم أداء الطالب على الاختبار التحريري" في صـالح عينـة المرتفعن. ورقم (Y) (Y)

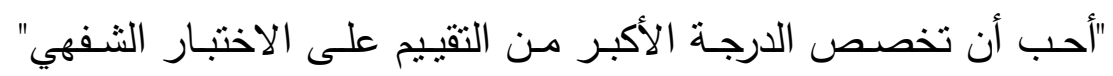


جاءت الفروق الدالة لصـالح رفض مضمون هذه الفقرة للعينات الثلاثتة

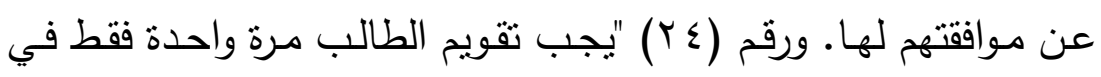
نهاية الفصل الدراسي" جاءت الفروق الدالة لصالح رفض مضمون هون هذه

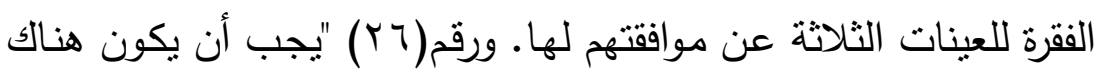

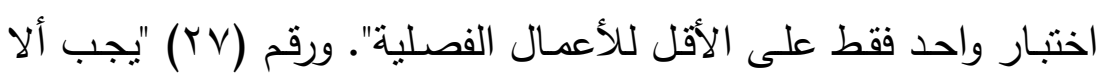
يكون هناك اختبارات للأعمال الفصلية ويكون تقويم للطالب معتمدا على الى

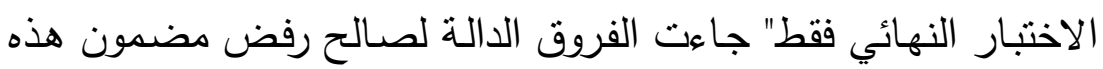

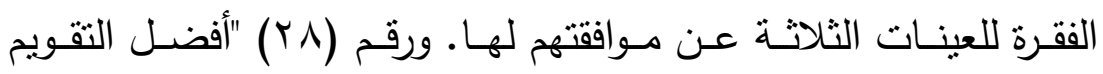
المستمر للطالب أثناء المحاضرات والأنشطة الخاصة بالمادة" في صالح عينة المرتفعين. ورقم (Y9) "يجب ألا يخصص للتقويم المستمر للطالب من جانب المعلم معظم الدرجات التقويمية" في صـالح عينة المرتفعين. ورقم (rr) "الزمن المحدد والمخصص للاختبار بشكل عام يحد من إبراز قدراتي ومواهبي الخاصـة". ورقم (ع ب) "أفضل أن تأتي أسئلة الاختبار في كل مواضيع وأجزاء المقرر" في صالح عينتي مرتفعي ومنخفضي واني

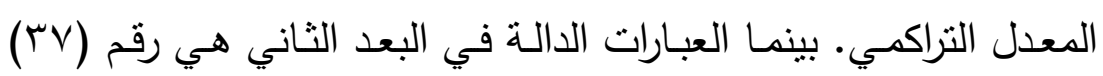

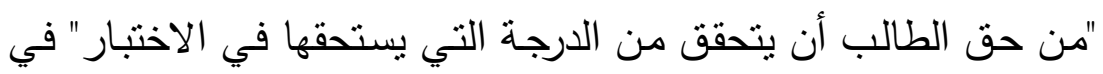

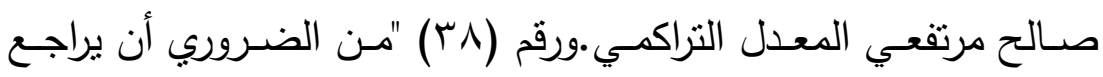

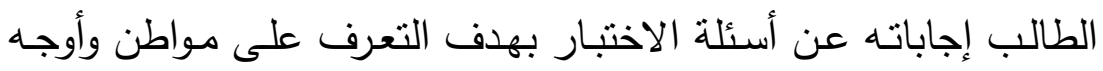

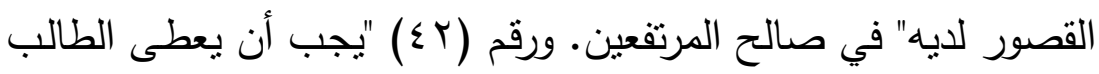

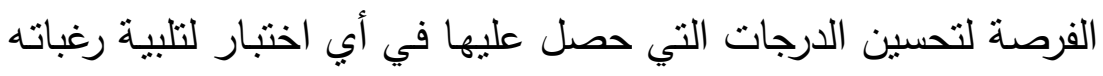

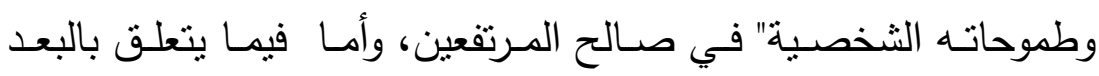

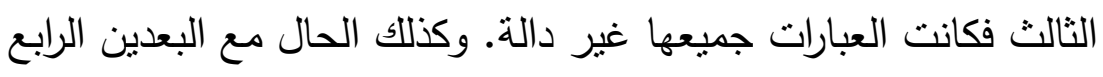
والخامس.

يتضح من المقارنات السابقة أن الاتجاهات الخاصة بعينات المقارنة

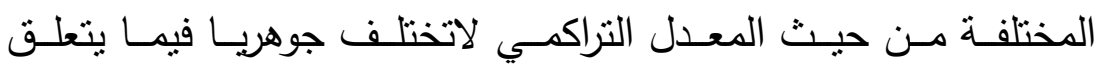


بالاختبار الثفهي الذي لم يبدو من خـلال النتائج السابقة دلالة لفروق تكرارات الموافقة عليه بين الطالبات مختلفات المعدل التراكمي وهذا مـا مانس

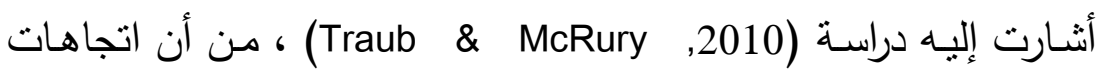
الطلاب نحو الاختبارات الثفهية والتحريرية لاتختلف باختلاف مستواهم

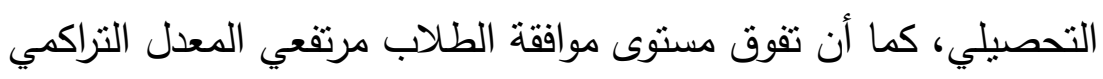

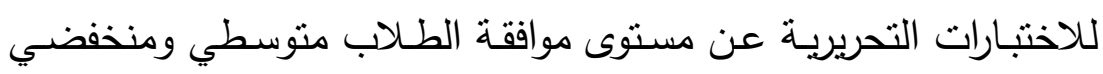

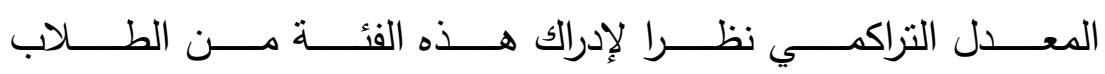

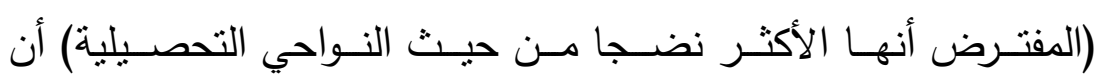

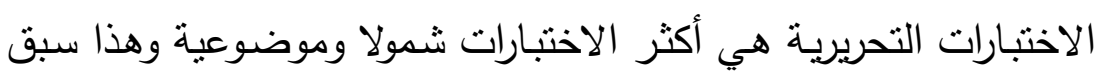

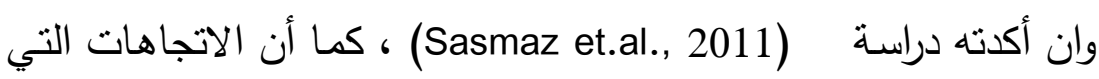
تظهر تفضيل جميع الطالبات على اختلاف معدلهن التراكمي للاختبارات

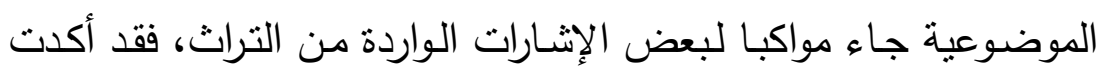
دراسة (1998, Birenbaum \& Feldman) أن الطلاب يفضلون الأسئلة الموضوعية، نظرا لأن هذا النوع من الأسئلة يحصل الطلاب بمقتضاها

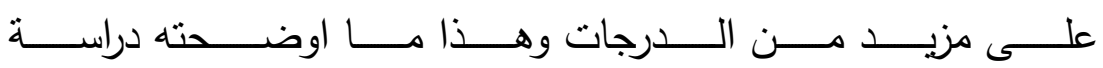

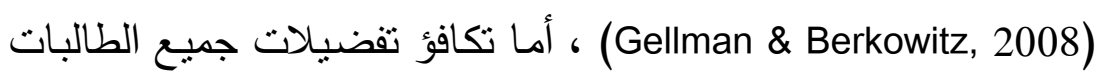
للاختبـار المـزيج مـن ( التحريـري والثـهـي) ، هـي نتيجـة غريبـة نظـرا لتساوي تفضيلات كل من عينتي المرتفعين والمنخفضين لهذه النوعية من الاختبار وقد تقسر هذه النتيجة بأن مرتفعات المعدل التراكمي يرغبن في لفي تتوع الاختبارات التي يمكن أن تعطي رؤيسة جيدة ومتكاملة عن أدائهن

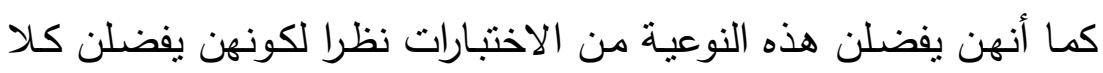

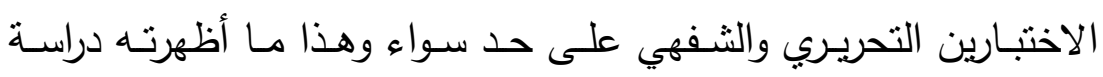

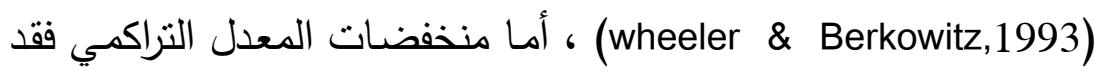
يجدن أن الاختبار الثفهي بجانب التحريري قد يمنح فرص غير متكافئة

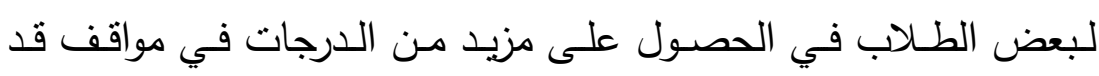


لاتتسم بالموضوعية أحيانا، أو يكون نتيجة لعدم جدية هذه الفئة للتعامل

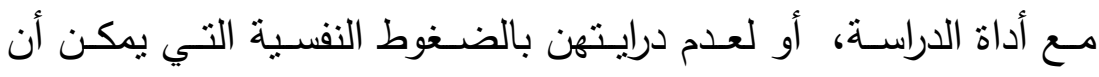

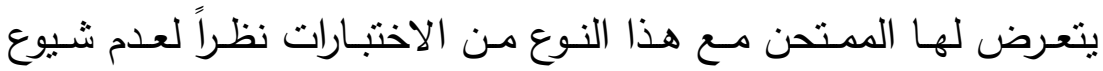
استخدامها في التعليم الجامعي في الواقع العربي إذا ماقورنت بالاختبارات

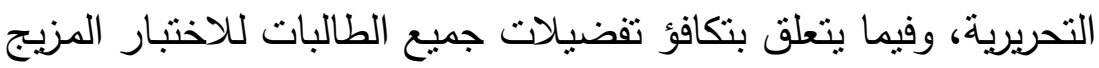

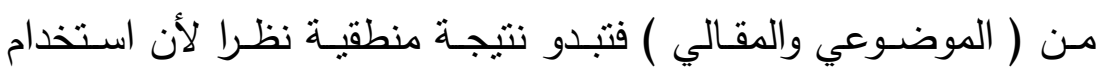
هذين النوعين يحدث نوعا من التكامل الذي يمكن من خلاله تقويم الأداء

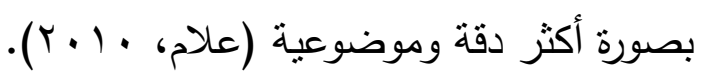
في ضوء النتائج التي تم التوصل إليها تقترح الدراسة ما يلي: - إجراء دراسة تستهدف الكثف عن المعوقات التي تحول دون استخدام

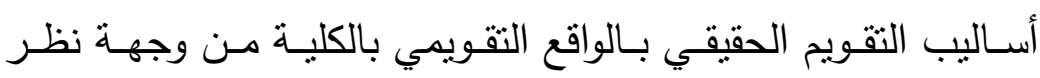
أعضاء الهيئة التدريسية والطلاب. - إجـراء دراسـة تسـتهدف التوصـل إلـى نمـوذج تقـويمي مقتـرح يمكن استخدامه بشكل موحد في تقويم أداء الطالب / الطالبة الجامعية. - إجراء دراسة تستهدف اقتراح نماذج تقويمية تتاسب كل قسم من أقسام

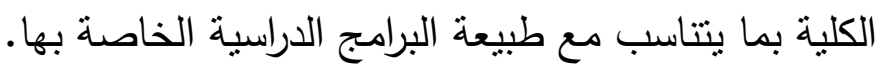

التوصيات

توصي الدراسة بضرورة الاطلاع على أراء الطالبات ورؤيتهن تجاه

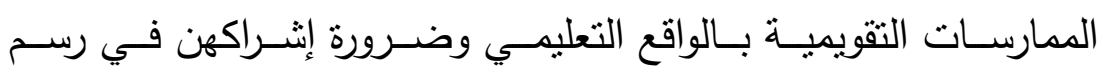

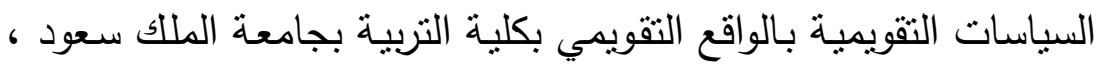
بهدف تحقيق موضوعية تقويم الأداء الأكاديمي للطالبات المنتسبات. خـاتمة

لقد انتهـت الدراسـة مـن خـلال الإجراءات الخاصـة بهـا إلى وجود اختلاف بين طالبات الأقسام العلمية المختلفة بجامعة الملك سعود حول الإهل توجهاتهم نحو أنـواع ووسـائل وإجراءات ومراحل التقويم ،وقد بـدا مـن بـن 
النتائج الاتجاهـات الإيجابيـة لطالبـات المستويات الأخيـرة بالكليـة نحو

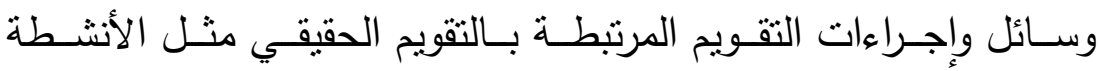

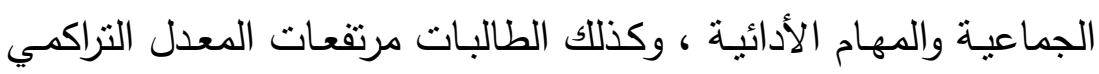

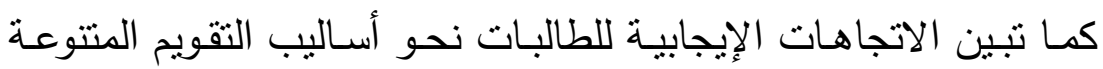
التي تتمثل في استخدام أنواع مختلفة من الاختبارات ووسـائل ومراحل التهل التقويم التي تغطي كل جوانب العمليـة التعلميـة ، وتوحي هذه النتائج

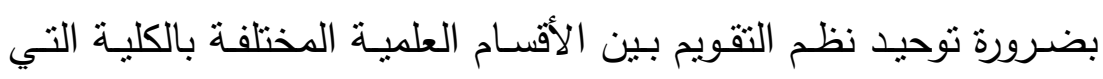

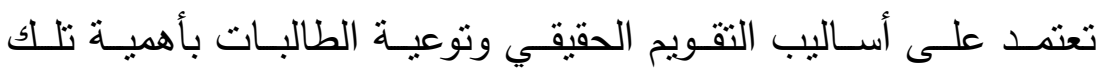

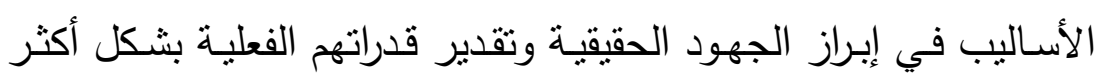
موضـوعية كما أن إثـراك الطالبـات في السياسـات التقويميـة مـن خـلال رؤيتهين التي تتسم بالنضج والوعي حيال الأساليب التقويمية والإجراءات

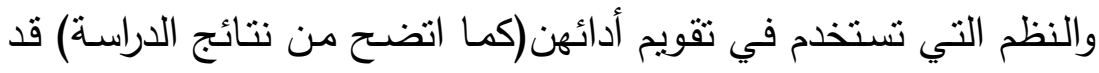

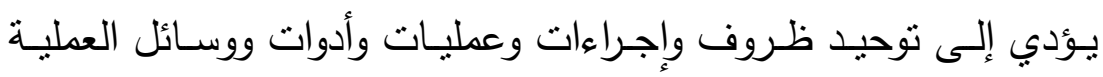
القويميـة وبالتـالي تحقف الموضـوعية المنشـودة في تقويم أداء طالبـات الكلية مستقبلاً. 


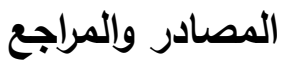

1. الذنيبات، محمد عبد الرحمن (^ . . ץ). أثر الاختبارات البنائية

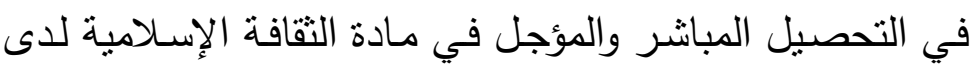

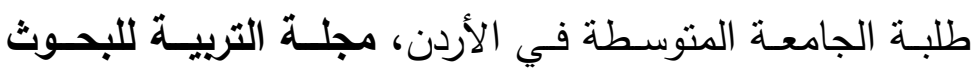

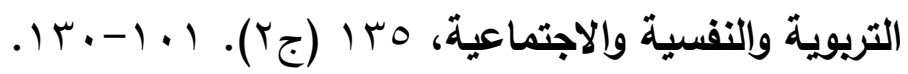

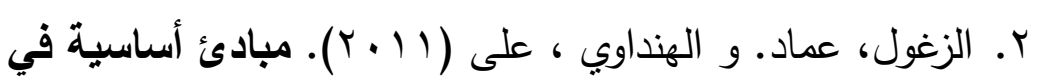
علم النفس، عمان: دار حنين للنشر والنوزيع.

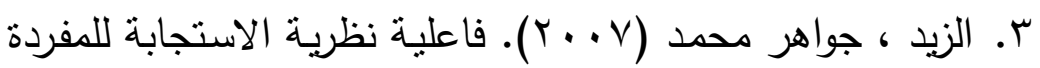

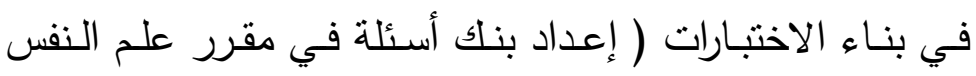
التربوي). رسالة دكتواره غير منشوره. جامعة الإمام محمد بن إعداء بن سعود الإسلامية، كلية العلوم الاجتماعية.

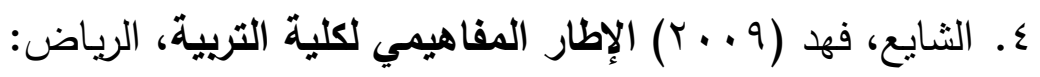
جامعة الملك سعود، كلية التربية.

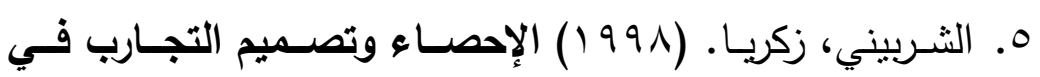
البحوث النفسية والتريويـة والاجتماعية، القاهرة. مكتبة النجلو

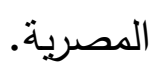
7. الثيخ، سليمان الخضري (11) (1). سيكلوجية الفروق الفردية في الأكاء، طب. عمان. دار المسيرة للنشر والتوزيع والطباعة.

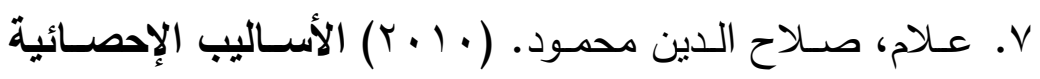
الاستدلالية البارمتريـة واللابارمتريـة في تحليل بيانات البحوث النفسية والتريوية. القاهرة. دار الفكر العربي.

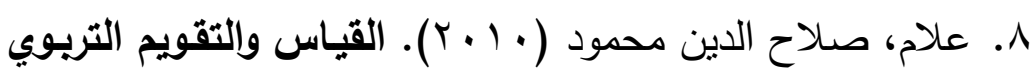
في العملية التذريسية. عمان. دار المسيرة للنشر والتوزيع. 


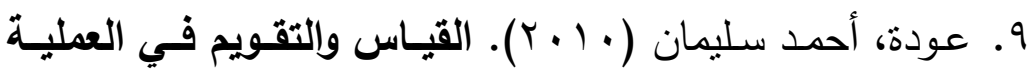

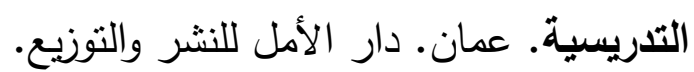

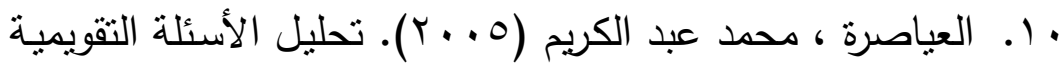

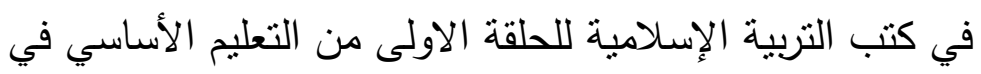

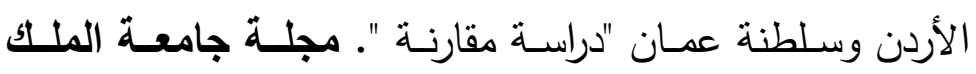

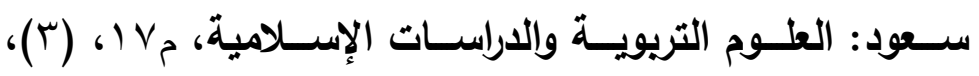
VTr-TA

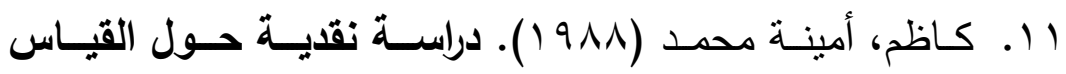

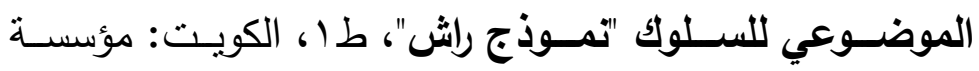

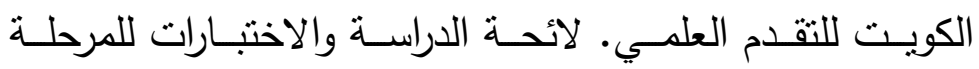

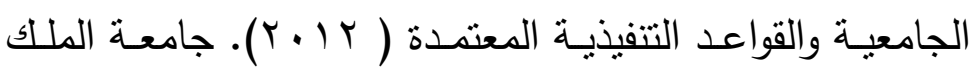
سعود، تعديل شهر محرم (س وس أه ).

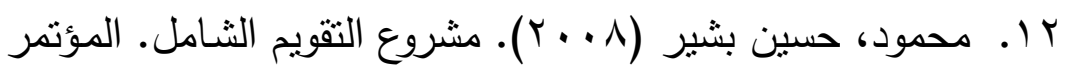

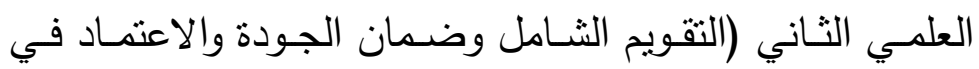

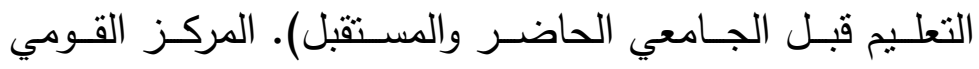
للادتحانات والتقويم التربوي. 11 - 1 - بr.

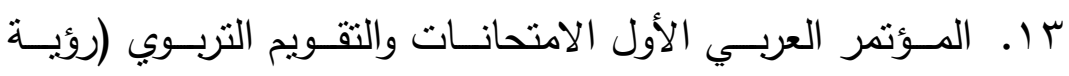

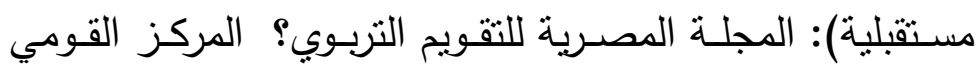

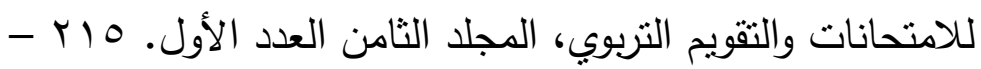
.411 ـ ا. نشواتي ،عبد المجيد(· ( • ؟).علم النفس التربوي . ، دار الفرقان

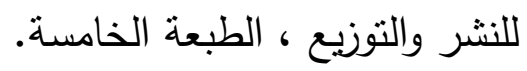




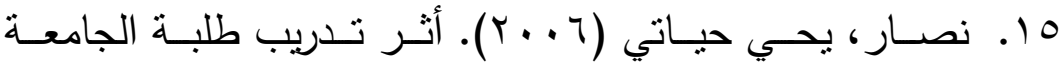

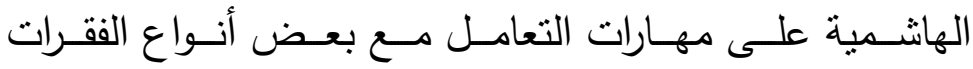

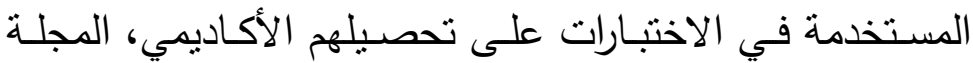

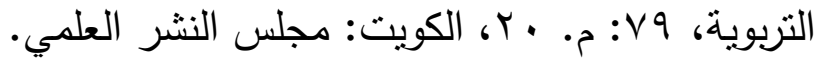

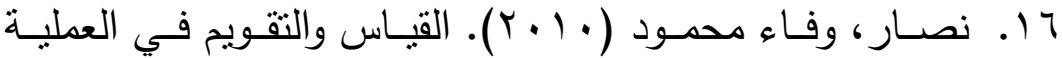

التعليمية، طا ـ الرياض: دار الزهراء.

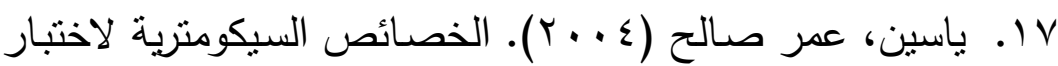

محكي المرجع في الكيمياء لطلاب الصف الأول الثنانوي العلمي

مقدرة وفق النظريتين الكلاسيكة والحديثة للقياس. رسالة دكتوارة

غير منشورة. كلية العلوم التربوية، جامعة عمان العربية.

18. Amy,D.;Donna L. ;Sundre, S.; \& Sara J.(2010).Exam Matters: Using the Student Opinion Scale for About Student Performance, the journal of general education, Vol. 58(3), 212-230.

19. Andrew ,T. ; Roach , A. \& Beddow, A.(2010). Incorporating Student Input in Developing Alternate Assessments Based on Modified Academic Achievement Standards. Council for Exceptional Children, Vol. 77(1), 61-80.

20. Aaron U.; Irina K. \& David S. (2005). Authentic Learning: Balancing Bloom's Cognitive and Affective Domains, Teaching of Psychology, Vol. 32(3), 154-160.

21. Baeten, M., Struyven, K., \&Dochy, F. (2008). Students' assessment preferences and approaches to learning in new learning environments: A replica study. Paper to be presented at the annual conference of the American Educational Research Association, March 2008, New York. 
22. Beller, M.; \&Gafni, N. (2000). Can item format (multiple choice vs. open-ended) account for gender differences in mathematics achievement? Sex Roles. A Journal of Research, 42, 1-21.

23. Ben-Chaim, D.; \& Zoller, U. (1997). Examinationtype preferences of secondary school students and their teachers in the science disciplines. Instructional Science, 25(5), 347-367.

24. Bennti, G.; \& Sinai, Y. (2007). Gender differences in multiple-choice tests: The role of differential guessing. Journal of Educational Measurement, 26, 23-35.

25. Birenbaum, M. (1997). Assessment preferences and their relationship to learning strategies and orientations.Higher Education, 33, 71-84.

26. Birenbaum, M. (2000). New insights into learning, teaching and the implications for assessment. Keynote address at the 2000 conference of the EARLI SIG on assessment and evaluation, September 13, Maastricht, The Netherlands.

27. Birenbaum, M.; \& Feldman, R. A. (1998). Relationships between learning patterns and attitudes towards twoassessment formats. Educational Research, 40(1), 90-97.

28. Bolt, S. E.; \& Roach, A. T. (2008). Including diverse learners in standards-based accountability: Promoting access to assessment and instruction. New York, NY: Guilfotd.

29. Boud, D. (2009). Assessment and the promotion of academic values. Studies in Higher Education, 15(1), 101-111.

30. Braxton, J. M.; \& M. R. Mann.( 2004). Incidence of student response to faculty teaching norm violations. New Directions for Teaching and Learning, vol 99, pp: $35-40$. 
31. Broekkamp, H., van Hout-Wolters, B., van den Bergh, H., \&Rijlaarsdam, G. (2004). 'Teachers'task demands, students' test expectation, and actual test content. British Journal of Educational Psychology, 74, 205-220.

32. Chen, Yao-Hsien ; Cheng, Ching-Hsue ; Liu, JingWei (2010).Entelligent Preference Selection Model Based on NRE for Evaluating Student Learning. Computers \& Education, Vol.54 (4), 916-926.

33. Christopher DeLucaa and Don A. Klinger (2010). Assessment literacy development: identifying gaps in teacher candidates' learning, Assessment in Education: Principles, Policy \& Practice. Vol. 17, No. 4, pp: 419-438

34. Chung, H ,Behan, K. (2010). Peer Sharing Facilitates the Effect of Inquiry-based Projects on Science Learning. American Biology Teacher, Vol. 72 Issue 1, 24-29

35. David, G., Filip, D. \& Janine, V. (2010). Students' assessment preferences, perceptions of assessment and their relationships to study results, High Educ. 56 PP: 645-658.

36. Education Commission of the States. (2010). Top of Form End-of-Course Exams: A Growing Trend in High School-Level Assessments. The Progress of Education Reform. Vol. 11(2.(

37. Eisner, E. (1996).overview of evaluation and Assessment: conception in search of practice in D.Boughton, E.Eisener, \& J.Ligtvoet (Eds).N.Y.: Teacher College Press.1-16.

38. Gellman, E.; \& Berkowitz, M. (2008). Test-item type: What students prefer and why. College Student Journal, 27(1), 17-26.

39. Gelman, E.S. \& Berkowitz, M. (1993).test item type: what students prefer and why. College student journal, 27, 17-26. 
40. Gerard, W.; David, G.; Filip, D. ; Janine, v.(2008). Students' assessment preferences, perceptions of assessment and their relationships to study results, High Educ, vol. 56, 645-658.

41. Gielen, S.; Dochy, F.; \& Dierick, S. (2003). Evaluating the consequential validity of new modes ofassessment: The influence of assessment on learning, including pre-, post-, and true assessment effects.In M. Segers, F. Dochy, \& E. Cascallar (Eds.), Optimising new modes of assessment: In search ofqualities and standards (pp. 37-54). Dordrecht: Kluwer Academic Publishers.

42. Glasner, A. (1999). Innovations in student assessment: A system-wide perspective. In S. Brown \& A. Glasner (Eds.), Assessment matters in higher education (pp. 14-27).Buckingham: SRHE andOpenUniversity Press.

43. Guskey, T. R.; \& Bailey J. M. (2001). Developing grading and reporting systems for student learning. Thousand Oaks, CA: Corwin Press.

44. Hamilton L. (2011). Preparing to take final examinations. Assessment \& Evaluation in Higher Education, 33 (2), 212-237.

45. Hartley. J; Nicholls L. (2009).Time of day, exam performance and new technology, British Journal of Educational Technology. Vol 39(3), 332-344.

46. Hicks, T. ; Lewis, L. ; Munn, G. ; Jordon, E. ; Charles, K.(2010). An Assessment of Teacher Education Students' Perceptions and Satisfaction of Their Learning Experiences in a Summer Pilot Program, College Quarterly. vol.13 (1), 19-25.

47. Hughes, G., (2011). Top of FormTowards a Personal Best: A Case for Introducing Ipsative Assessment in Higher Education, Studies in Higher Education. vol.36 (3), 353-367. 
48. Hurwitz, J. T., Elliott, S. N., \& Braden, J. P. (2007). The influence of test familiarity and student disability status upon teachers' judgments of students' test performance.School Psychology Quarterly, 22, 115-144.

49. Jacqueline P. L.; Rebecca J.; Gokiert, M.; Ken, C. \& Colleen, H., (2010). Teacher beliefs about the cognitive diagnostic information of classroomversus large-scale tests: implications for assessment literacy, Assessment in Education: Principles, Policy \& Practice Vol. 17(1), 7-21

50. James, B. (2011). Assessing reflective thinking: preservice teachers' and professors' perceptions of an oral examination, Assessment in Education: Principles, Policy \& Practice. Vol. 17, No. 1, 77-89

51. Ketterlin-Geller, L; Yovanof F, P.; \& Tindal, G. (2009). Developing a new paradigm for conducting research on accommodations in mathematics testing. Exceptional Children, 73, 331-347.

52. Kherfi, S. (2011).Top of Form Whose Opinion Is It Anyway? Determinants of Participation in Student Evaluation of Teaching, Journal of Economic Education. vol.42 n1 PP: 19-30.

53. Kucuk, F.; Walters, J. (2009).ELT Journal: English Language Teachers Journal. Vol. 63 (4), 332-341.

54. Kuhlemeier, H.; de Jonge, A.; \& Kremers, E. (2004). Flexibilisering van centraleexamens. Cito: Arnhem, C. J., \& Richardson, J. T. E. (2002). Approaches to studying and perceptions of academic quality in distance education. Higher Education, 44, 257-282.

55. Lawness, C. J.; \& Richardson, J. T. E. (2002). Approaches to studying and perceptions of academic quality in distance education. Higher Education, vol. $44,257-282$. 
56. Linda, D.; Hammond, N.; \& Ruth, C. (2010).Evaluating teacher education outcomes: a study of the Stanford Teacher Education Programme. Journal of Education for Teaching. Vol. 36(4), 369388.

57. MacLellan, E. (2011). Assessment for learning: The differing perceptions of tutors and students. Assessment\& Evaluation in Higher Education, vol. 15, 202-222.

58. Meisinger, E. B., Bradley, B. A., Schwanenflugel, P. J.,Kuhn, M. R., \& Morris, R. D. (2009). Myth and reality of the word caller: The relation between teacher nominations and prevalence among elementary school children.School Psychology Quarterly, 24, 147-159.

59. Michael E.; Charles H. (2010). The Effects of Grading and Teaching Practices on Students' Perceptions of Grading Fairness, COLLEGE TEACHING, vol.58, 93-98.

60. Michelle, A. Drouin (2010). Group-Based Formative Summative Assessment Relates to Improved Student Performance and Satisfaction. Teaching of Psychology, 37, 114-118.

61. Nevo, D. (2010). 'The influence of assessment method on students' learning approaches: Multiple choice question examination versus assignment essay.Higher Education, 35, PP.453-472.

62. Newhouse, C. P. (2011). Using IT to Assess IT: Towards Greater Authenticity in Summative Performance Assessment, Computers \& Education, and vol.56 (1)388-402. 
63. Ocak, G. ; Yildiz, S. (2011).Top of Form The Evaluation of the Applicability of the Social Studies Curriculum in Multigrade Teaching in Terms of Teacher Views (A Qualitative Research), Educational Sciences: Theory and Practice, vol.11 (2) , 873-879.

64. Ozogul, G. , Sullivan. H. (2009). Student performance and attitudes under formative evaluation by teacher, self and peer evaluators, Education Tech Research. Vol.57, 393-410.

65. Sasmaz, O.; Fatma ; Ormanci, U. ; Evrekli, E. (2011).The Science and Technology Pre-Service Teachers' Self-Efficacy Levels and Opinions about Alternative Assessment and Evaluation Approaches, Educational Sciences: Theory and Practice, v.11 (3), 1690-1698.

66. Scherz, Z. ; Bialer, L. ; Eylon, B. (2011).Top of FormTowards Accomplished Practice in Learning Skills for Science (LSS): The Synergy between Design and Evaluation Methodology in a Reflective CPD Programme, Research in Science \& Technological Education, v.29 (1), 49-69.

67. Scouller, K. (1998). 'The influence of assessment method on students' learning approaches: Multiple choicequestion examination versus assignment essay. Higher Education, 35, 453-472.

68. Scouller, K. M.; \& Prosser, M. (1994). 'Students' experiences in studying for multiple choice question examinations. Studies in Higher Education, vol.19(3), 267-279.

69. Segers, M.; \& Dochy, F. (2001). New assessment forms in problem-based learning: The value-added of the students' perspective. Studies in Higher Education, vol. 26(3), 327-343. 
70. Segers, M.; Dochy, F., \&Cascallar, E. (2003). The era of assessment engineering: Changing perspectives on teaching and learning and the role of new modes of assessment. In M. Segers, F. Dochy, \& E. Cascallar (Eds.), Optimising new modes of assessment: In search of qualities and standards (pp. 1-12). Dordrecht: Kluwer Academic Publishers.

71. Shepard, L. A. (2000). The role of assessment in a learning culture. Educational Researcher, 29(7), 414.

72. Simons, R.; van der Linden, J.; \& Duffy, T. (2000). New learning: Three ways to learn in a new balance.In R. J.; Simons, J.; van der, L.; \& Duffy, T. (Eds.), New learning (pp. 1-20). Dordrecht: Kluwer Academic Publishers.

73. Smith, C. S.; Folkard, S.; Schmieder, R. A.; Parra, L. F.; Speleten, E.; \& Almiral, H. (2008). Investigation of morning-evening orientations and other variables for exam using the preferences scale, Personality and Individual Differences, vol.32, 949-968.

74. Stiggins, R. (2002). Assessment crisis: The absence of assessment for learning. Phi Delta Kappan, 83 (10), 758-65.

75. Stiggins, R. (2004). New assessment beliefs for a new school mission. Phi Delta Kappan 86, (1), 22-7.

76. Struyf, E.; Vandenberghe, R.; \& Lens, W. (2001). The evaluation practice of teachers as a learningopportunity for students. Studies in Educational Evaluation, 27(3), 215-238.

77. Tang, J. ; Harrison, C. (2011).Investigating University Tutor Perceptions of Assessment Feedback: Three Types of Tutor Beliefs, Assessment \& Evaluation in Higher Education, v.36 (5 ), 583604 
78. Tasdemir, M. (2010). A Comparison of MultipleChoice Tests and True-False, Matching Tests Used in Evaluating Student Progress, Journal of Instructional Psychology, 37( 3), 258-266.

79. Tavakol, M.; Dennick, R. (2011). Post-examination analysis of objective tests. Medical Teacher; 33(6), 447-458.

80. Traub, R. E.; \& MacRury, K. (2010). Multiple choice vs. free response in the testing of scholastic achievement. . British Journal of Educational Psychology, 33, 177-298.

81. User's Guide. SPSS Inc. (2010). IBM SPSS Statistics 19 Core System. IBM Company.

82. Volante, L., and X. Fazio. 2007. Exploring teacher candidates' assessment literacy: Implications for teacher education reform and professional development. Canadian Journal of Education 30, (3), 749-70.

83. Watering, G.; \& Rijt, J. (2006). Teachers and students' perceptions of assessments: A review and a study into the ability and accuracy of estimating the difficulty levels of assessment intems. Educational Research Review, vol. 1(2), 133-147. 


\section{الملاحق}

جدول (؛ ) قائمة المحكمين لاداة

\begin{tabular}{|c|c|c|}
\hline الارجة العلمية & اسم المحكم & 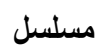 \\
\hline استاذ علم النفس كلية التربية جامعة الملك سعود & استاذ دكتور /فه الاليم & -1 \\
\hline استاذ مشارك كلية التربية جامعة الملك سعود & دكتور / محمد الثافعي & $-r$ \\
\hline استاذ مشارك كلية التربية جامعة الملك سعود & دكتور /محمد القضاة & $-r$ \\
\hline استاذ مشارك كلية التربية جامعة الملك سعود & دكتورة / غادة عبد الغفار & $-\varepsilon$ \\
\hline استاذ مشارك كلية التربية جامعة الملك سعود & دكتورة / نوره القحطاني & -0 \\
\hline استاذ مساعد كلية التربية جامعة الملك سعود & دكتورة / بسمة الحلو & -9 \\
\hline استاذ مساعد كلية التربية جامعة الملك سعود & دكتور / خالد زيادة & $-v$ \\
\hline استاذ مساعد كلية التربية جامعة الملك سعود & دكتورة / شريفة الغامدي & $-\Lambda$ \\
\hline استاذ مساعد كلية التربية جامعة الملك سعود & دكتورة / فاتن أبو طالب & -9 \\
\hline استاذ مساعد كلية التربية جامعة الملك سعود & دكتور / فيصل عبد الفتاح & -1 \\
\hline استاذ مساعد كلية التربية جامعة الملك سعود & دكتورة / منال محمود & -11 \\
\hline استاذ مساعد كلية التربية جامعة الملك سعود & دكتورة / ام هاشم العمدة & $-1 r$ \\
\hline
\end{tabular}


جدول رقم (•)التكرار والنسب المئوية لاستجابات العينة الكلية للاراسة على فقرات البعد الأول

\begin{tabular}{|c|c|c|c|c|}
\hline \multicolumn{5}{|c|}{ (التفضيلات الخاصة بالاختبارات) من مقياس اتجاهات الطالبات نحو أساليب التقويم } \\
\hline المئوية & 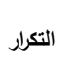 & ن الاستجابة & محتوى الفقرة & رقفرة \\
\hline 26.1 & 136 & 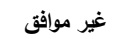 & \multirow{2}{*}{ أفضل الاختبارات التي تحتوي على أسئلة موضوعية فقط. } & \multirow[t]{2}{*}{ q1 } \\
\hline 73.9 & 386 & 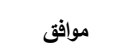 & & \\
\hline 16.1 & 84 & غير موافق & \multirow{2}{*}{ أفضل أسئلة الاختيار من متعدد عن أنواع الأسئلة الأخرى. } & \multirow[t]{2}{*}{ q2 } \\
\hline 83.9 & 438 & 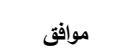 & & \\
\hline 45.6 & 238 & غير موافق & \multirow{2}{*}{ أفضل أسئلة الصواب والخطأ عن أنواع الأسئلة الأخرى. } & \multirow[t]{2}{*}{$\mathrm{q3}$} \\
\hline 54.4 & 284 & 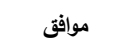 & & \\
\hline 80.8 & 422 & غير موافق & \multirow{2}{*}{ أفضل أسئلة الإكمال عن أنواع الأسئلة الأخرى. } & \multirow[t]{2}{*}{ q4 } \\
\hline 19.2 & 100 & 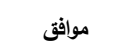 & & \\
\hline 40.4 & 211 & غير موافق & \multirow{2}{*}{ أفضل أسئلة المزاوجة عن أنواع الأسئلة الأخرى. } & \multirow[t]{2}{*}{ q5 } \\
\hline 59.6 & 311 & 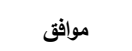 & & \\
\hline 14.4 & 75 & غير موافق & \multirow{2}{*}{ أفضل أسئلة الإجابة القصيرة عن أنواع الأسئلة الأخرى. } & \multirow[t]{2}{*}{ q6 } \\
\hline 85.6 & 447 & 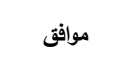 & & \\
\hline 84.1 & 439 & غير موافق & \multirow{2}{*}{ أفضل الاختبار الذي يحتوي على أسئلة مقالية فقط . } & \multirow[t]{2}{*}{$\mathrm{q} 7$} \\
\hline 15.9 & 83 & 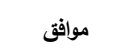 & & \\
\hline 85.1 & 444 & غير موافق & \multirow{2}{*}{ أحب الأسئلة المقائية التي تحتاج لشرح دقيق ومفصل. } & \multirow[t]{2}{*}{ q8 } \\
\hline 14.9 & 78 & 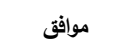 & & \\
\hline 85.4 & 446 & غير موافق & \multirow{2}{*}{ لا يهمني نوع أسئلة الاختبار ولا أفضل نوع بعينه من الأسئلة. } & \multirow[t]{2}{*}{ q9 } \\
\hline 14.6 & 76 & 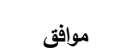 & & \\
\hline 60.5 & 316 & 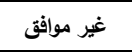 & \multirow{2}{*}{ أفضل أن يحتوي الاختبار الواحد على نوعية واحدة من الأسئلة } & \multirow[t]{2}{*}{ q10 } \\
\hline 39.5 & 206 & 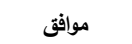 & & \\
\hline 42.1 & 220 & 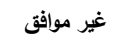 & \multirow{2}{*}{ أفضل أن لا تزيد أنواع أسئلة الاختبار الواحد عن نوعين من الأسئلة } & \multirow[t]{2}{*}{ q11 } \\
\hline 57.9 & 302 & 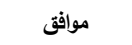 & & \\
\hline 24.3 & 127 & غير موافق & \multirow{2}{*}{ أفضل أن يحتوي الاختبار الواحد أنواع مختلفة من الأسئلة الموضوعية. } & \multirow[t]{2}{*}{ q12 } \\
\hline 75.7 & 395 & 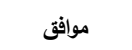 & & \\
\hline 35.1 & 183 & 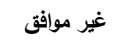 & \multirow{2}{*}{ أفضل أن يحتوي الاختبار الواحد على خليط من الأسئلة الموضوعية } & \multirow{2}{*}{ q13 } \\
\hline 64.9 & 339 & 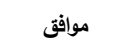 & & \\
\hline 16.1 & 84 & غير موافق & \multirow{2}{*}{ أفضل الأسئلة التي لا تستغرق وقتا طويلا أوتفكير عميقا للإجابة عنها. } & \multirow[t]{2}{*}{ q14 } \\
\hline 83.9 & 438 & موافق & & \\
\hline 55.7 & 291 & 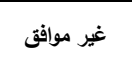 & \multirow{2}{*}{ الاختبارات الثفهية وسيلة موضوعية يمكن الاعتماد عليها بشكل أساسي } & \multirow[t]{2}{*}{$q 15$} \\
\hline 44.3 & 231 & 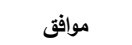 & & \\
\hline
\end{tabular}


اتجاهات طالبات كلية التربية بجامعة الملك سعود نحو أساليب التقويم د. عفاف سالم د. وفاء محمود د. وداد عبدالرحمن

\begin{tabular}{|c|c|c|c|c|}
\hline المئوية & 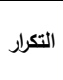 & 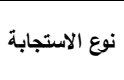 & 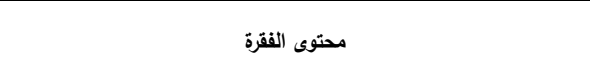 & الفقرة \\
\hline 25.1 & 131 & 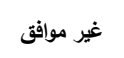 & \multirow{2}{*}{ لاختبارات التحريرية أكثر موضوعية في تقويم الطالب من الاختبارات } & \multirow[t]{2}{*}{ q16 } \\
\hline 74.9 & 391 & موافق & & \\
\hline 39.8 & 208 & 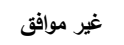 & \multirow{2}{*}{ لا أفضل الاختبارات الثفهية في تقويم مستوى أدائي. } & \multirow[t]{2}{*}{ q17 } \\
\hline 60.2 & 314 & 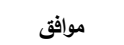 & & \\
\hline 25.5 & 133 & 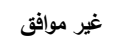 & \multirow{2}{*}{ أفضل الاختبارات التحريرية في تقويم مستوى أدائي. } & \multirow[t]{2}{*}{ Q18 } \\
\hline 74.5 & 389 & 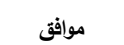 & & \\
\hline 48.3 & 252 & 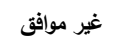 & \multirow{2}{*}{ أفضل أن يكون التقويم مزيج من الاختبارات الثفهية والأخرى التحريرية. } & \multirow[t]{2}{*}{ q19 } \\
\hline 51.7 & 270 & موافق & & \\
\hline 26.6 & 139 & 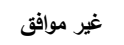 & \multirow{2}{*}{ أحب أن تخصص الارجة الأكبر من تقييم أداء الطالب على الاختبار } & \multirow[t]{2}{*}{$\mathbf{q 2 0}$} \\
\hline 73.4 & 383 & موافق & & \\
\hline 74.5 & 389 & 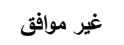 & \multirow{2}{*}{ أحب أن تخصص الدرجة الأكبر من التقييم على الاختبار الشفهي. } & \multirow[t]{2}{*}{ q21 } \\
\hline 25.5 & 133 & 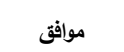 & & \\
\hline 19.9 & 104 & غير موافق & \multirow{2}{*}{ يجب أن يخصص درجة لتقويم أداء الطالب من خلال مشاركته في } & \multirow[t]{2}{*}{$q 22$} \\
\hline 80.1 & 418 & 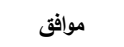 & & \\
\hline 8.2 & 43 & غير موافق & \multirow{2}{*}{ كلما كان الاختبار يحتوى على أسئلة كثيرة ومتنوعة كان ذلك أفضل في } & \multirow[t]{2}{*}{ q23 } \\
\hline 91.8 & 479 & 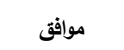 & & \\
\hline 68.2 & 356 & غير موافق & \multirow[b]{2}{*}{ يجب تقويم الطالب مرة واحدة فقط في نهاية الفصل الدراسي. } & \multirow[t]{2}{*}{ q24 } \\
\hline 31.8 & 166 & 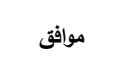 & & \\
\hline 17.4 & 91 & 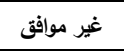 & \multirow{2}{*}{ يجب أن تكون هناك اختبارات متعددة للأعمال الفصلية تضاف الدرجات } & \multirow[t]{2}{*}{$q 25$} \\
\hline 82.6 & 431 & 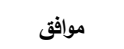 & & \\
\hline 38.9 & 203 & 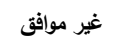 & \multirow[b]{2}{*}{ يجب أن يكون هناك اختبار واحد فقط على الأقل للأعمال الفصلية. } & \multirow{2}{*}{$q 26$} \\
\hline 61.1 & 319 & موافق & & \\
\hline 83.1 & 434 & 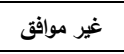 & \multirow{2}{*}{ 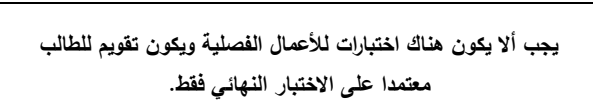 } & \multirow[t]{2}{*}{$\mathbf{q 2 7}$} \\
\hline 16.9 & 88 & 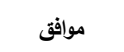 & & \\
\hline 35.6 & 186 & 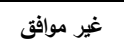 & \multirow[b]{2}{*}{ أفضل التقويم المستمر للطالب أثناء المحاضرات والأنشطة الخاصة بالمادة. } & \multirow[t]{2}{*}{ q28 } \\
\hline 64.4 & 336 & 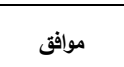 & & \\
\hline 35.6 & 186 & غير موافق & \multirow{2}{*}{ يجب ألا يخصص للتقويم المستمر للطالب من جانب المعلم معظم الارجات } & \multirow[t]{2}{*}{ q29 } \\
\hline 64.4 & 336 & 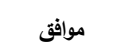 & & \\
\hline 15.5 & 81 & غير موافق & \multirow[b]{2}{*}{ أفضل أن تكون هناك درجات خاصة لتقويم الطالب تعطي للانضباط داخل } & \multirow{2}{*}{ q30 } \\
\hline 84.5 & 441 & موافق & & \\
\hline
\end{tabular}

$\varepsilon \cdot \wedge$ 
المجلد الخامس والعشرون (العدد الرايع) لسنة 10 • ب

مجلة كلية التربية ـ جامعة الإسكندرية

\begin{tabular}{|c|c|c|c|c|}
\hline المئوية & التكرار & 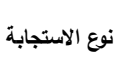 & محتوى الفقرة & رقفرة \\
\hline 27 & 141 & غير موافق & \multirow{2}{*}{ أفضل أن تكون هناك درجات خاصة لتقويم الطالب تعطي لنسبة الحضور. } & \multirow[t]{2}{*}{ q31 } \\
\hline 73 & 381 & 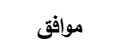 & & \\
\hline 33.9 & 177 & غير موافق & \multirow{2}{*}{ يجب يقوم أداء الطالب من جانب أستاذ المادة بعد نهاية كل موضوع أو } & \multirow[t]{2}{*}{932} \\
\hline 66.1 & 345 & 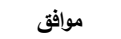 & & \\
\hline 37.7 & 197 & غير موافق & \multirow{2}{*}{ الزمن المدد والمخصص للاختبار بشكل عام يحد من إبراز قدراتي } & \multirow[t]{2}{*}{ q33 } \\
\hline 62.3 & 325 & 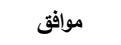 & & \\
\hline 28.4 & 148 & غير موافق & \multirow{2}{*}{ أفضل أن تأتي أسئلة الاختبار في كل مواضيع و أجزاء المقرر. } & \multirow[t]{2}{*}{ q34 } \\
\hline 71.6 & 374 & 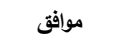 & & \\
\hline 47.3 & 247 & غير موافق & \multirow{2}{*}{ الأنثطة الفردية أفصل من الجماعية في إبراز مواهبي وإمكانيتي } & \multirow[t]{2}{*}{ q35 } \\
\hline 52.7 & 275 & 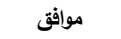 & & \\
\hline 43.9 & 229 & غير موافق & \multirow{2}{*}{ الاختبارات المقالية أفضل من الاختبارات الموضوعية في إبراز مواهبي } & \multirow[t]{2}{*}{ q36 } \\
\hline 56.1 & 293 & 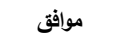 & & \\
\hline
\end{tabular}

جدول (؟) التكرار والنسب المئوية لاستجابات العينة الكلية للاراسة على فقرات البعد الثاني

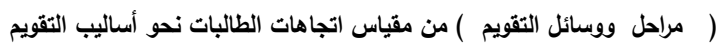

\begin{tabular}{|c|c|c|c|c|}
\hline 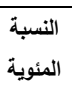 & التكرار & نوع الاستجابة & محتوى الفقرة & الفقرة \\
\hline 6.1 & 32 & غير موافق & \multirow[b]{2}{*}{ من حق الطالب أن يتحقق من اللارجة التي يستحقها في الاختبار . } & \multirow[t]{2}{*}{ q37 } \\
\hline 93.9 & 490 & موافق & & \\
\hline 7.7 & 40 & غير موافق & \multirow[b]{2}{*}{ من الضروري آن يراجع الطالب إجاباته عن أسئلة الاختبار بهاف } & \multirow[t]{2}{*}{ q38 } \\
\hline 92.3 & 482 & موافق & & \\
\hline 63.8 & 333 & غير موافق & \multirow[b]{2}{*}{ يجب ان تخصص للأسئلة المقالية الدرجات الأكبر عن الأسئلة } & \multirow[t]{2}{*}{ q39 } \\
\hline 36.2 & 189 & موافق & & \\
\hline 12.8 & 68 & غير موافق & \multirow[b]{2}{*}{ أفضل الأسئلة السهلة التي يستطيع أن يجيب عنها الغالبية الغظمى } & \multirow[b]{2}{*}{ q40 } \\
\hline 87 & 454 & موافق & & \\
\hline 77.8 & 406 & غير موافق & \multirow[b]{2}{*}{ يجب أن يحتوي الاختبار على أسئلة لا يستطيع أن يجيب عنها } & \multirow[t]{2}{*}{ q41 } \\
\hline 22.2 & 116 & موافق & & \\
\hline 7.3 & 38 & غير موافق & \multirow{2}{*}{ يجب أن يعطى الطالب الفرصة لتحسين الدرجات التي حصل عليها في } & \multirow[t]{2}{*}{$q 42$} \\
\hline 92.7 & 484 & موافق & & \\
\hline 14.6 & 76 & غير موافق & \multirow[b]{2}{*}{ 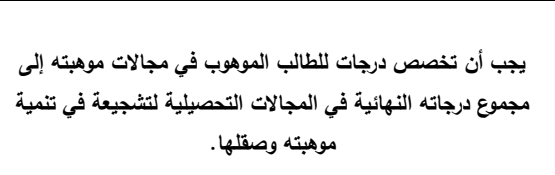 } & \multirow[b]{2}{*}{$q 43$} \\
\hline 85.4 & 446 & موافق & & \\
\hline
\end{tabular}


اتجاهات طالبات كلية التربية بجامعة الملك سعود نحو أساليب التقويم د. عفاف سالم د. وفاء محمود د. وداد عبدالرحمن

\begin{tabular}{|c|c|c|c|c|}
\hline 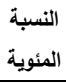 & التكرار & نوع الاستجابة & محتوى الفقرة & 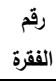 \\
\hline 42.7 & 223 & غير موافق & \multirow{2}{*}{ أحب أن يعلم زملائي الارجات التي أحصل عليها في جميع } & \multirow[t]{2}{*}{$\mathrm{q} 44$} \\
\hline 57.3 & 299 & موافق & & \\
\hline 48.5 & 253 & غير موافق & \multirow[b]{2}{*}{ 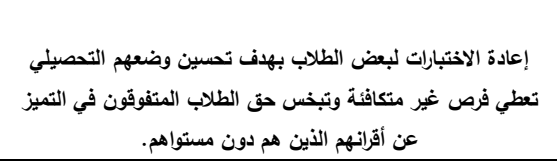 } & \multirow{2}{*}{$\mathrm{q} 45$} \\
\hline 51.5 & 269 & موافق & & \\
\hline 9.8 & 51 & غير موافق & \multirow[b]{2}{*}{ من حق الطالب أن يحسن مستواه حتى وإن أراد أن يحصل على درجة } & \multirow[t]{2}{*}{$q 46$} \\
\hline 90.2 & 471 & موافق & & \\
\hline 8.2 & 43 & غير موافق & \multirow[b]{2}{*}{ أحتاج أجازة كافيه قبل الاختبار حتى أتتكن من السبطرة والتحكم في } & \multirow[t]{2}{*}{947} \\
\hline 91.8 & 479 & موافق & & \\
\hline 12.8 & 67 & غير موافق & \multirow{2}{*}{ من حقي تأجيل التقويم إن لم أكن مستعدا بشكل جيد للاختبار. } & \multirow[t]{2}{*}{ q48 } \\
\hline 87.2 & 455 & موافق & & \\
\hline 23.9 & 125 & غير موافق & \multirow[b]{2}{*}{ 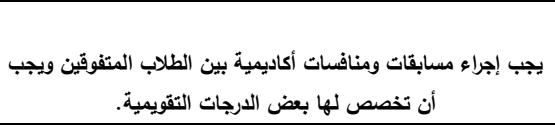 } & \multirow[t]{2}{*}{ q49 } \\
\hline 76.1 & 397 & موافق & & \\
\hline 8.6 & 45 & غير موافق & \multirow[b]{2}{*}{ يجب أن يوفر أستاذ المادة أو النظم داخل الكلية العديد من نماذج النقات } & \multirow[t]{2}{*}{$q 50$} \\
\hline 91.4 & 477 & موافق & & \\
\hline 5.4 & 28 & غير موافق & \multirow[b]{2}{*}{ من الضروري أن يجيب أستاذ المادة على أسئلة اختبارات الأعمال } & \multirow[t]{2}{*}{ q51 } \\
\hline 94.6 & 494 & موافق & & \\
\hline 19.7 & 103 & غير موافق & \multirow[b]{2}{*}{ يجب استبعاد مواضيع المقرر التي وردت بها أسئلة باختبارات الأعمال } & \multirow[t]{2}{*}{ q52 } \\
\hline 80.3 & 419 & موافق & & \\
\hline
\end{tabular}

جدول (V) التكرار والنسب المئوية لاستجابات العينة الكلية للاراسة على فقرات البعد الثالث

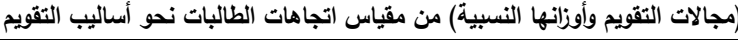

\begin{tabular}{|c|c|c|c|c|}
\hline 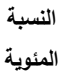 & التكرار & ن الاستجابة & محتوى الفقرة & 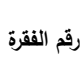 \\
\hline 16.7 & 87 & 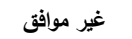 & \multirow[b]{2}{*}{ يجب أن تتخصص الدرجة الأكبر في تقويم الطالب على الأعمال الفصلية } & \multirow[t]{2}{*}{ q53 } \\
\hline 83.3 & 435 & 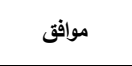 & & \\
\hline 10.2 & 53 & 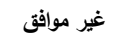 & \multirow[b]{2}{*}{ يجب أن يعتد تقويم الطالب بناء على مرجع واحد (كتاب واحد فقط) فقط أستاذ المقرز. } & \multirow[t]{2}{*}{ q54 } \\
\hline 89.8 & 469 & 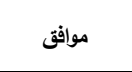 & & \\
\hline 40.6 & 212 & 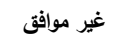 & \multirow{2}{*}{ يجب أن يكون للقراءات المتعددة للطالب نتيجة إطلاعه على أكثر من مرجع الثريع } & \multirow[t]{2}{*}{ q55 } \\
\hline 59.4 & 310 & موافق & & \\
\hline 21.8 & 114 & 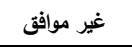 & \multirow[b]{2}{*}{ 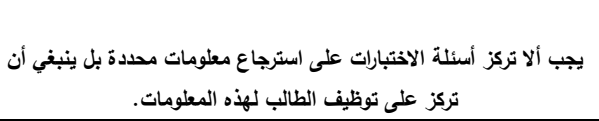 } & \multirow[t]{2}{*}{ q56 } \\
\hline 78.2 & 408 & 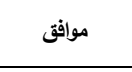 & & \\
\hline 25.1 & 131 & 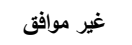 & \multirow{2}{*}{ يجب أن تخصص أسئلة لقياس الجوانب الابتكارية والإبداعية لاى الطالب. } & \multirow[t]{2}{*}{ q57 } \\
\hline 74.9 & 391 & موافق & & \\
\hline
\end{tabular}


المجلد الخامس والعشرون (العدد الرابع) لسنة 10

مجلة كلية التربية ـ جامعة الإسكندرية

\begin{tabular}{|c|c|c|c|c|}
\hline 69 & 360 & غير موافق & \multirow{2}{*}{ يجب أن تستتد عملية تقويم الطالب في الاختبار النهائي لأستاذ آخر بذلاف } & \multirow[t]{2}{*}{ q58 } \\
\hline 31 & 162 & 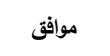 & & \\
\hline 49.8 & 260 & غير موافق & \multirow{2}{*}{ يجب ألا ينفرد أستاذ المادة بتصحيح جميع أسئلة اختبارات طلابه ويجب أن } & \multirow[t]{2}{*}{ q59 } \\
\hline 50.2 & 262 & موافق & & \\
\hline 16.9 & 88 & غير موافق & \multirow[b]{2}{*}{ تزاحم وكثرة الاختبارات بجدول الامتحانات النهائي في نهاية الفصل الدراسي } & \multirow[t]{2}{*}{$q 60$} \\
\hline 83.1 & 434 & موافق & & \\
\hline 19.9 & 104 & غير موافق & \multirow{2}{*}{ يجب أن يخصص للطالب الحاصل على تقديرات مرتفعة في أغلب المقررات } & \multirow[t]{2}{*}{ q61 } \\
\hline 80.1 & 418 & موافق & & \\
\hline 15.1 & 79 & غير موافق & \multirow[b]{2}{*}{ يمكن أن أحصل على تقدير أفضل لأدائي عندما أشاريك زملائي في الأنثطة } & \multirow[t]{2}{*}{$q 62$} \\
\hline 84.9 & 443 & موافق & & \\
\hline 15.5 & 81 & غير موافق & \multirow{2}{*}{ يجب أن ألا يحرم الطالب من الامتحانات وفقا لنسبة الحضور . } & \multirow[t]{2}{*}{$q 63$} \\
\hline 84.5 & 441 & موافق & & \\
\hline 49.4 & 258 & غير موافق & \multirow[b]{2}{*}{ الاختبارات الموضوعية تمنح في كثير من الأحيان الطلاب درجات أكثر مما } & \multirow[t]{2}{*}{ q64 } \\
\hline 50.4 & 263 & موافق & & \\
\hline 56.3 & 294 & غير موافق & \multirow[b]{2}{*}{ الاختبارات الموضوعية اختبارات سطية لا تعطي صورة حقيقية عن تمكن } & \multirow[t]{2}{*}{ q65 } \\
\hline 43.7 & 228 & موافق & & \\
\hline 23.2 & 121 & غير موافق & \multirow[b]{2}{*}{ 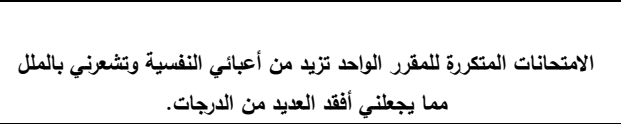 } & \multirow[t]{2}{*}{$q 66$} \\
\hline 76.8 & 401 & موافق & & \\
\hline 15.7 & 82 & غير موافق & \multirow[b]{2}{*}{ 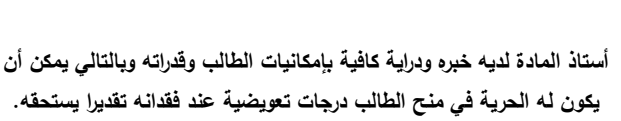 } & \multirow[t]{2}{*}{ q67 } \\
\hline 84.3 & 440 & موافق & & \\
\hline 22.4 & 117 & غير موافق & \multirow[b]{2}{*}{ أحب الأسئلة التي تعتد على النواحي التطبيقية أكثر من تلك التي تركز على } & \multirow[t]{2}{*}{$q 68$} \\
\hline 77.6 & 405 & موافق & & \\
\hline
\end{tabular}

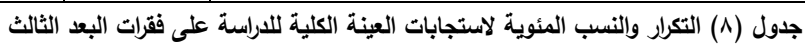

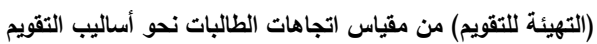

\begin{tabular}{|c|c|c|c|c|}
\hline 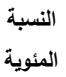 & التكرار & نوع الاستجابة & محتوى الفقرة & رقم الفقرة \\
\hline 9.6 & 50 & غير موافق & \multirow[b]{2}{*}{ 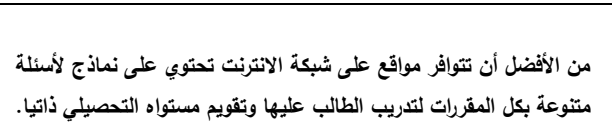 } & \multirow[t]{2}{*}{ q69 } \\
\hline 90.4 & 472 & موافق & & \\
\hline 8.2 & 43 & غير موافق & \multirow[b]{2}{*}{ سرعة إعلان الدرجات التقويمية تجعل أمام الطالب الفرصة الكافية والوقت في } & \multirow[t]{2}{*}{ q70 } \\
\hline 91.8 & 479 & موافق & & \\
\hline 15.3 & 80 & غير موافق & \multirow[b]{2}{*}{ القيود التي تفرضها النظم لمراجعة الطلاب للارجاتهم في الاختبارات النهائية } & \multirow[t]{2}{*}{ q71 } \\
\hline 84.5 & 441 & موافق & & \\
\hline 13.4 & 70 & غير موافق & \multirow{2}{*}{ لابد أن يحتفظ الطالب بنسخة من الاختبار في نهاية الموقق الامتحاني لمراجعة إجاباته } & \multirow[t]{2}{*}{$q 72$} \\
\hline 86.6 & 452 & موافق & & \\
\hline
\end{tabular}


اتجاهات طالبات كلية التربية بجامعة الملك سعود نحو أساليب التقويم د. عفاف سالم د. وفاء محمود د. وداد عبدالرحمن

\begin{tabular}{|c|c|c|c|c|}
\hline 22.6 & 118 & غير موافق & \multirow[b]{2}{*}{ الضغوط النفسية التي يتعرض لها الطلاب بالامتحانات الثفهية أكثر من تلك التبات } & \multirow[t]{2}{*}{$q 73$} \\
\hline 77.2 & 404 & موافق & & \\
\hline 31 & 162 & غير موافق & \multirow[b]{2}{*}{ يجب أن يخصص لوضوح الخط ونظافة الورقة وحسن تنظيم الطالب للإجابة } & \multirow[t]{2}{*}{$q 74$} \\
\hline 69 & 360 & موافق & & \\
\hline 20.7 & 108 & غير موافق & \multirow[b]{2}{*}{ يجب أن لا يحرم الطالب من تقدير الإجابة الصواب على بعض أسئلة الاختبار } & \multirow[t]{2}{*}{$q 75$} \\
\hline 79.3 & 414 & موافق & & \\
\hline 37.9 & 198 & غير موافق & \multirow[b]{2}{*}{ خروج بعض المتحنين من اللجنة قبل نهاية الزمن المخصص للاختبار يزيد } & \multirow[t]{2}{*}{976} \\
\hline 62.1 & 324 & موافق & & \\
\hline 12.6 & 66 & غير موافق & \multirow[b]{2}{*}{ يجب أن يمنح الطالب مزيدا من الوقت بعد نهاية الزمن المخصص للاختبار } & \multirow[t]{2}{*}{$q 77$} \\
\hline 87.4 & 456 & موافق & & \\
\hline
\end{tabular}

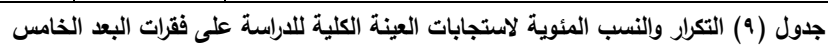

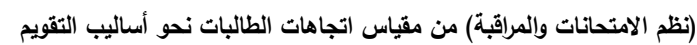

\begin{tabular}{|c|c|c|c|c|}
\hline 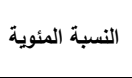 & التكرار & الاستجابة & محتوى الفقرة & رقفر \\
\hline 15.3 & 80 & غير موافق & \multirow{2}{*}{ الحركة الاائمة للمراقب داخل قاعة الامتحان يفقدني بعض من تركيزي. } & \multirow[t]{2}{*}{ q78 } \\
\hline 84.7 & 442 & 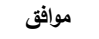 & & \\
\hline 19.5 & 102 & 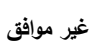 & \multirow{2}{*}{ 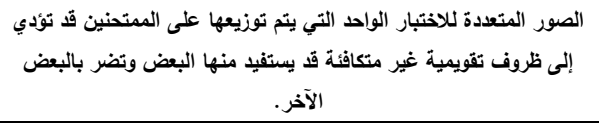 } & \multirow[t]{2}{*}{ q79 } \\
\hline 80.5 & 420 & 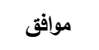 & & \\
\hline 31.4 & 164 & 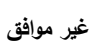 & \multirow{2}{*}{ 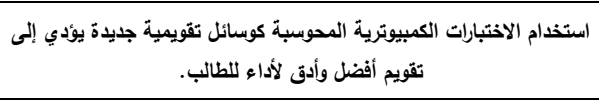 } & \multirow[t]{2}{*}{ q80 } \\
\hline 68.6 & 358 & موافق & & \\
\hline 31.6 & 165 & 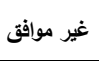 & \multirow{2}{*}{ 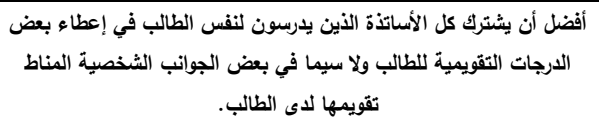 } & \multirow[t]{2}{*}{ q81 } \\
\hline 68.4 & 357 & موافق & & \\
\hline 20.1 & 105 & 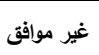 & \multirow{2}{*}{ 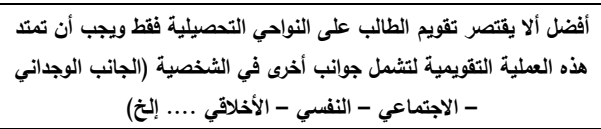 } & \multirow[t]{2}{*}{ q82 } \\
\hline 79.7 & 417 & 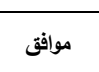 & & \\
\hline 13.2 & 69 & غير موافق & \multirow{2}{*}{ 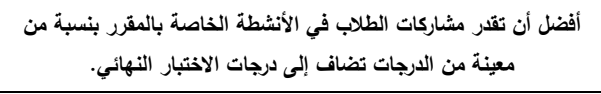 } & \multirow[t]{2}{*}{ q83 } \\
\hline 86.6 & 452 & موافق & & \\
\hline 10 & 52 & غير موافق & \multirow{2}{*}{ 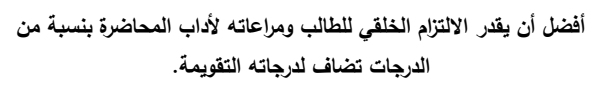 } & \multirow[t]{2}{*}{ q84 } \\
\hline 90 & 470 & 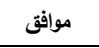 & & \\
\hline 16.1 & 84 & غير موافق & \multirow{2}{*}{ أفضل عدم إعادة تقويم الطالب في نفس موضوعات المقرر والتي سبق بق بق من قبل. } & \multirow[t]{2}{*}{ q85 } \\
\hline 83.9 & 438 & موافق & & \\
\hline 10 & 52 & غير موافق & \multirow{2}{*}{ 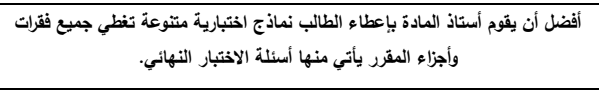 } & \multirow[t]{2}{*}{986} \\
\hline 89.8 & 469 & 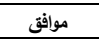 & & \\
\hline 26.8 & 140 & 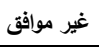 & \multirow{2}{*}{ أفضل أن يكلف الطالب بإجراء واجبات منزلية يخصص لها جزء من الارجة } & \multirow[t]{2}{*}{ q87 } \\
\hline 73.2 & 382 & 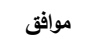 & & \\
\hline 43.9 & 229 & غير موافق & \multirow[t]{2}{*}{ أفضل أن يقوم أداء الطالب في نهاية كل محاضرة. } & \multirow[t]{2}{*}{$\mathrm{q} 88$} \\
\hline 55.9 & 293 & 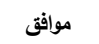 & & \\
\hline
\end{tabular}




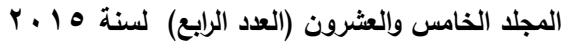

مجلة كلية التربية ـ جامعة الإسكندرية

\begin{tabular}{|c|c|c|c|c|}
\hline 35.2 & 184 & 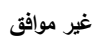 & \multirow{2}{*}{ أفضل أن يقوم أداء الطالب في نهاية كل وحدة دراسية. } & \multirow[t]{2}{*}{$\mathbf{q} 89$} \\
\hline 64.8 & 338 & 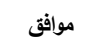 & & \\
\hline 27.4 & 143 & 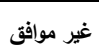 & \multirow{2}{*}{ أفضل أنتخص نسبة من الارجة التقويمية على نسبةحضور الطالبل } & \multirow[t]{2}{*}{ q90 } \\
\hline 72.6 & 379 & 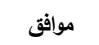 & & \\
\hline
\end{tabular}

جدول ( • 1) دالالة الفروق بين تكرارات الموافقة وعدم الموافقة بين الأقسام العلمية بكلية التربيةعلى فقرات البعد الأول من

مقياس الدراسة (التفضيلات الخاصة بالاختبارات)

\begin{tabular}{|c|c|c|c|c|c|}
\hline \multirow{3}{*}{$\begin{array}{l}\text { المجموع } \\
220 \\
\end{array}$} & \multicolumn{2}{|c|}{$q 11$} & & & \multirow{12}{*}{ قسم } \\
\hline & موافقت & غر موافقة & & & \\
\hline & $137 a$ & $83 a$ & التكرلر. & \multirow[t]{2}{*}{ علم نفس } & \\
\hline $100.0 \%$ & $62.3 \%$ & $37.7 \%$ & النسبة \% & & \\
\hline 138 & $66 \mathrm{~b}$ & $72 a$ & التكرار. & \multirow{2}{*}{ رياض أطفال } & \\
\hline $100.0 \%$ & $47.8 \%$ & $52.2 \%$ & النسبة \% & & \\
\hline 8 & 8 & 4 & التكراد & \multirow[t]{2}{*}{ ثقافة اسلامية } & \\
\hline $100.0 \%$ & $67.0 \%$ & $33.0 \%$ & النسبة \% & & \\
\hline 136 & $79 a$ & $57 a$ & التكرلـ & \multirow[t]{2}{*}{ تربية خاصة } & \\
\hline $100.0 \%$ & $58.1 \%$ & $41.9 \%$ & النسبة \% & & \\
\hline 16 & $13 a$ & $3 a$ & التكراد & \multirow[t]{2}{*}{ فنية } & \\
\hline $100.0 \%$ & $81.3 \%$ & $18.8 \%$ & النسبة \% & & \\
\hline 518 & 301 & 217 & التكرال & \multirow{2}{*}{\multicolumn{2}{|c|}{ المجموع }} \\
\hline $100.0 \%$ & $58.1 \%$ & $41.9 \%$ & النسبة \% & & \\
\hline \multicolumn{3}{|c|}{$12.019 \mathrm{a}$} & \multicolumn{3}{|c|}{ قيمة اختبار كا r r } \\
\hline \multirow[t]{2}{*}{ المجموع } & \multicolumn{2}{|c|}{ q13 } & & & \\
\hline & موافقت & غير موافق & & & \\
\hline 220 & $137 a$ & $83 a$ & التكرار & \multirow{2}{*}{ علم نفس } & \multirow{10}{*}{ قسم } \\
\hline $100.0 \%$ & $62.3 \%$ & $37.7 \%$ & النسبة \% & & \\
\hline 138 & $95 a$ & $43 a$ & التكراد & \multirow[t]{2}{*}{ رياض أطفال } & \\
\hline $100.0 \%$ & $68.8 \%$ & $31.2 \%$ & النسبة \% & & \\
\hline 8 & 5 & 7 & التكرار & \multirow[t]{2}{*}{ ثقافة اسلامية } & \\
\hline $100.0 \%$ & $42 \%$ & $58 \%$ & النسبة \% & & \\
\hline 136 & $98 a$ & $38 a$ & التكرال & \multirow[t]{2}{*}{ تربية خاصة } & \\
\hline $100.0 \%$ & $72.1 \%$ & $27.9 \%$ & النسبة \% & & \\
\hline 16 & $6 \mathrm{~b}$ & $10 a$ & التكرار & \multirow[t]{2}{*}{ فنية } & \\
\hline $100.0 \%$ & $37.5 \%$ & $62.5 \%$ & النسبة \% & & \\
\hline 518 & 339 & 179 & التكراد & & \\
\hline $100.0 \%$ & $65.4 \%$ & $34.6 \%$ & النسبة \% & & \\
\hline المجموع & & & & & \\
\hline & موافقة & غر موافقت & & & \\
\hline 220 & $175 b$ & $45 a$ & التكراد & علد نفس & \\
\hline $100.0 \%$ & $79.5 \%$ & $20.5 \%$ & النسبة \% & علم تقس & \\
\hline 138 & $121 a$ & $17 a$ & التكراد & رياض أطفال & \\
\hline $100.0 \%$ & $87.7 \%$ & $12.3 \%$ & النسبة \% & ريط الص ل & قسم \\
\hline 8 & 8 & 4 & التكراد & ثقافة اسلامية & \\
\hline $100.0 \%$ & $67.0 \%$ & $33.0 \%$ & النسبة \% & لعاته السفحية & \\
\hline 136 & $122 a$ & $14 a$ & التكرار & تربية خاصة & \\
\hline $100.0 \%$ & $89.7 \%$ & $10.3 \%$ & النسبة \% & تريئ صصش & \\
\hline 16 & $15 a$ & $1 a$ & التكراد & فنتة & \\
\hline $100.0 \%$ & $93.8 \%$ & $6.3 \%$ & النسبة \% & تبيّة & \\
\hline 518 & 439 & 79 & التكرار & & \\
\hline $100.0 \%$ & $84.7 \%$ & $15.3 \%$ & النسبة \% & & \\
\hline & $9.703 a$ & & & اختبار كا r & \\
\hline المحموع & & & & & \\
\hline المجبولح & موافقي & غير موافقت & & & \\
\hline 220 & $168 \mathrm{a}$ & $52 a$ & التكرل & & \\
\hline $100.0 \%$ & $76.4 \%$ & $23.6 \%$ & النسبة \% & & \\
\hline 138 & $107 a$ & $31 a$ & التكرال & رياض أطفار & \\
\hline $100.0 \%$ & $77.5 \%$ & $22.5 \%$ & النسبة \% & ريص & قسم \\
\hline 8 & 9 & 3 & التكراد & ثقافة اسلامية & \\
\hline $100.0 \%$ & $75 \%$ & $25 \%$ & النسبة \% & & \\
\hline 136 & $93 a$ & $43 a$ & التكرار & تربية خاصة & \\
\hline $100.0 \%$ & $68.4 \%$ & $31.6 \%$ & النسبة \% & & \\
\hline 16 & $6 b$ & $10 a$ & التكىل. & فنسة & \\
\hline
\end{tabular}




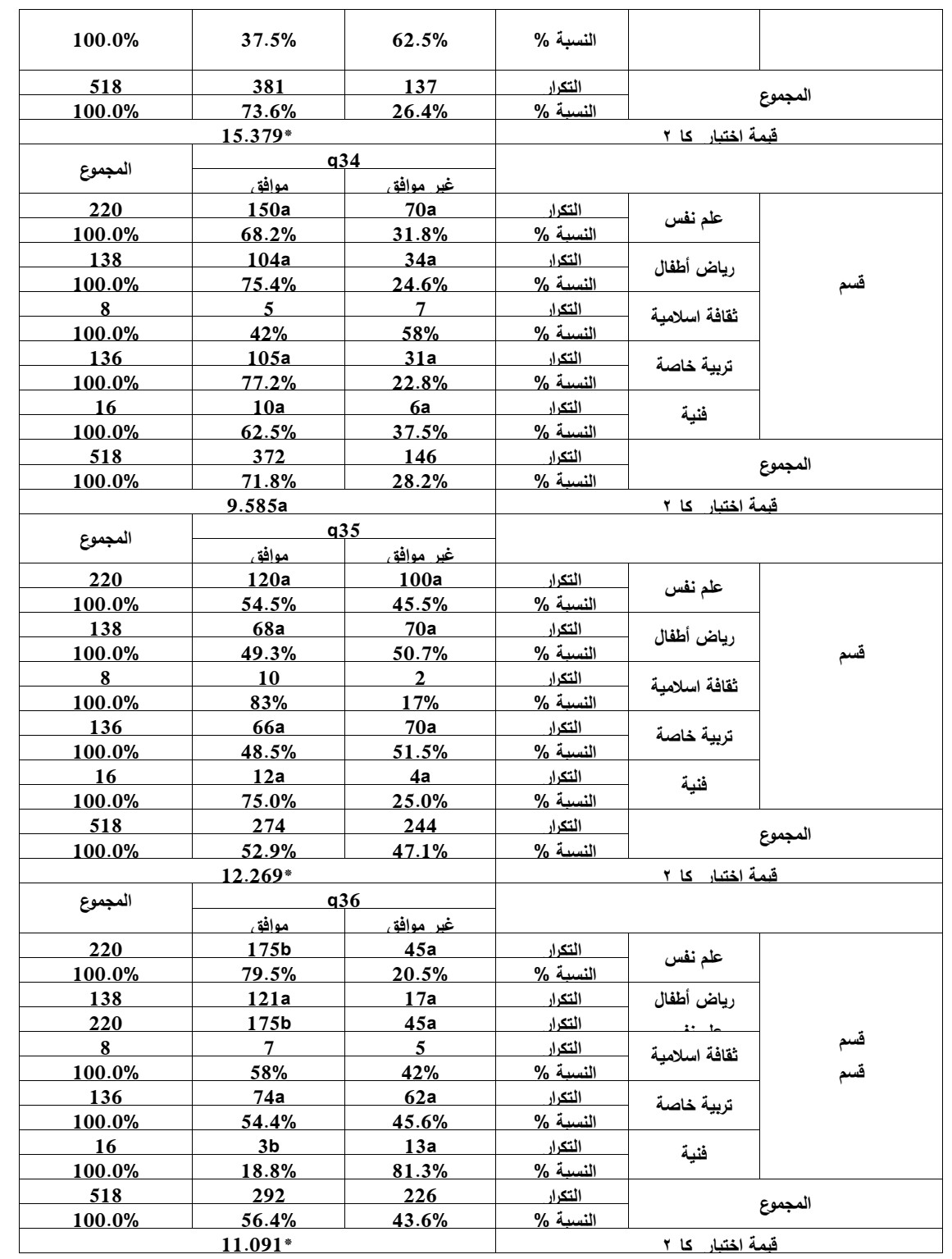

جدول (1 (1) نتائج اختبار مربع كاي لالالة الفروق والنسب المئوية لتكرارات الاستجابة على فقرات البعد الثاني

\begin{tabular}{|c|c|c|c|c|c|}
\hline \multirow{2}{*}{ المجموع } & \multicolumn{2}{|c|}{ q38 } & & \multirow{4}{*}{ علم نفس } & \\
\hline & موافة & غي موافت & & & \multirow{11}{*}{ قسم } \\
\hline 220 & $201 a$ & $19 a$ & التكرار & & \\
\hline $100.0 \%$ & $91.4 \%$ & $8.6 \%$ & النسبة \% & & \\
\hline 138 & $135 b$ & $3 a$ & التكرار & \multirow{2}{*}{ رياض أطفال } & \\
\hline $100.0 \%$ & $97.8 \%$ & $2.2 \%$ & النسبة \% & & \\
\hline 8 & 6 & 6 & التكرار & \multirow{2}{*}{ ثقافة اسلامية } & \\
\hline $100.0 \%$ & $\mathbf{5 0 . 0 \%}$ & $50.0 \%$ & النسبة \% & & \\
\hline 136 & $124 a$ & $12 a$ & التكرار & \multirow{2}{*}{ تربية خاصة } & \\
\hline $100.0 \%$ & $91.2 \%$ & $8.8 \%$ & النسبة \% & & \\
\hline 16 & $16 a$ & 0a & التكرار & \multirow{2}{*}{ فنية } & \\
\hline $100.0 \%$ & $100.0 \%$ & $0.0 \%$ & النسبة \% & & \\
\hline 518 & 480 & 38 & التكرار & \multirow{2}{*}{\multicolumn{2}{|c|}{ المجموع }} \\
\hline $100.0 \%$ & $92.7 \%$ & $7.3 \%$ & النسبة \% & & \\
\hline
\end{tabular}




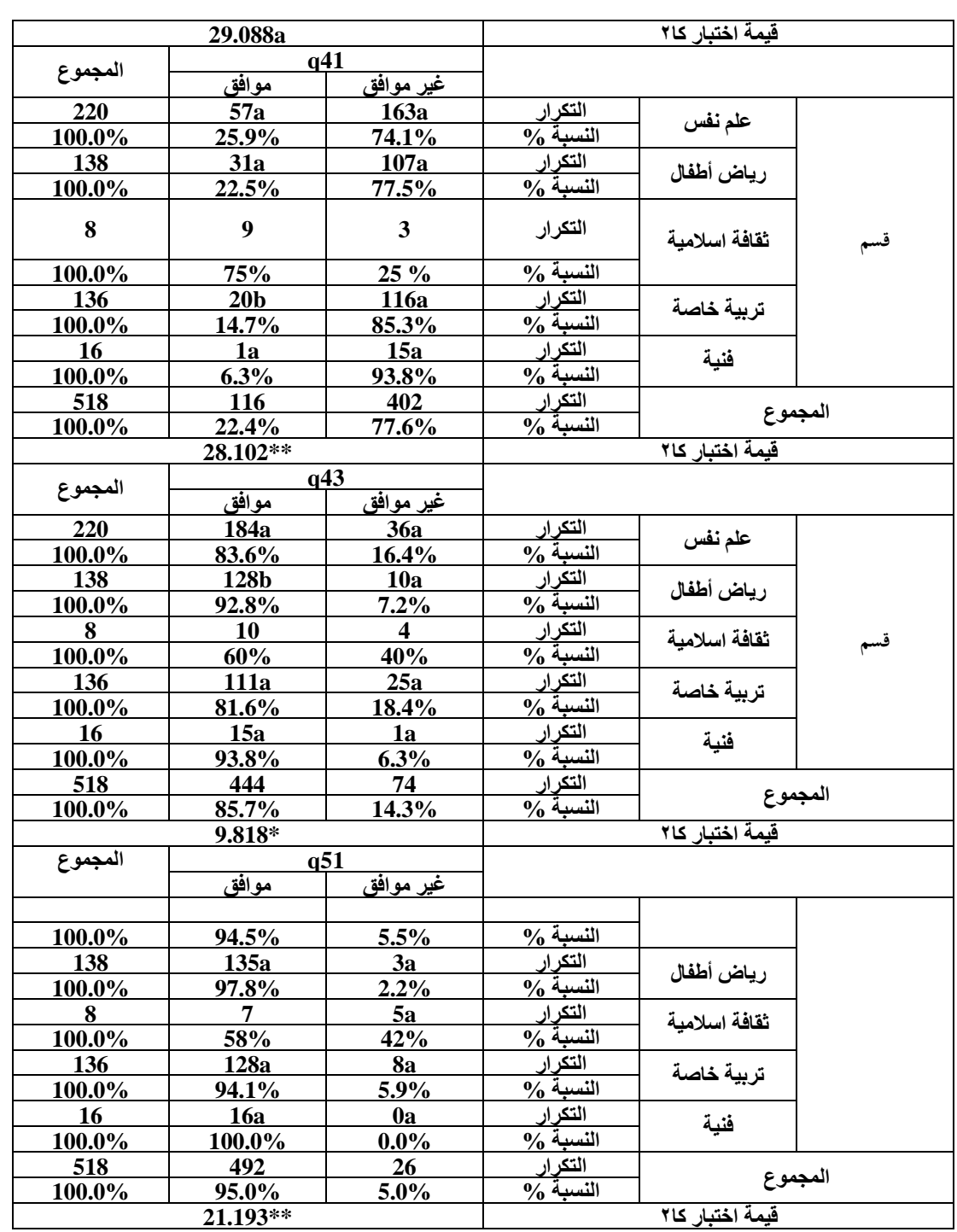

جدول (r Y ) نتائج اختبار مربع كاي لالالة الفروق بين تكرارات و النسب المئوية للاستجابات على فقرات البعد الثالث

\begin{tabular}{|c|c|c|c|c|c|}
\hline \multirow{2}{*}{ المجموع } & \multicolumn{2}{|c|}{ a54 } & & \multirow{4}{*}{ علم نفس } & \multirow{12}{*}{ قسم } \\
\hline & موافق & غير موافق & & & \\
\hline 220 & 193a & $27 \mathbf{a}$ & التكرار & & \\
\hline $100.0 \%$ & $87.7 \%$ & $12.3 \%$ & النسبة \% & & \\
\hline 138 & 128a & 10a & التكرار & \multirow{2}{*}{ رياض أطفال } & \\
\hline $100.0 \%$ & $92.8 \%$ & $7.2 \%$ & النسبة \% & & \\
\hline 8 & 7 & 5 & التكرار & \multirow{2}{*}{ ثقافة اسلامية } & \\
\hline $100.0 \%$ & $58 \%$ & $42 \%$ & النسبة \% & & \\
\hline 136 & $126 a$ & $10 \mathrm{a}$ & التكرار & \multirow{2}{*}{ تربية خاصة } & \\
\hline $100.0 \%$ & $92.6 \%$ & $7.4 \%$ & النسبة \% & & \\
\hline 16 & $15 \mathbf{a}$ & $1 a$ & التكرار & \multirow{2}{*}{ فنية } & \\
\hline $100.0 \%$ & $93.8 \%$ & $6.3 \%$ & النسبة \% & & \\
\hline 518 & 467 & 51 & التكرار & \multirow{2}{*}{\multicolumn{2}{|c|}{ المجموع }} \\
\hline $100.0 \%$ & $90.2 \%$ & $9.8 \%$ & النسبة \% & & \\
\hline \multicolumn{3}{|c|}{$10.588 *$} & \multicolumn{2}{|c|}{ قيمة اختبار كاب } & \\
\hline المجموع & & & & & \\
\hline
\end{tabular}




\begin{tabular}{|c|c|c|c|c|c|}
\hline & موافق & غير موافث & & & \\
\hline 220 & $156 \mathrm{~b}$ & $64 a$ & التكرار & \multirow{2}{*}{ علم نفس } & \multirow{10}{*}{ قسم } \\
\hline $100.0 \%$ & $70.9 \%$ & $29.1 \%$ & النسبة \% & & \\
\hline 138 & 116b & $22 a$ & التكرار & \multirow{2}{*}{ رياض أطفال } & \\
\hline $100.0 \%$ & $84.1 \%$ & $15.9 \%$ & النسبة \% & & \\
\hline 8 & 7 & 5 & التكرار & \multirow{2}{*}{ ثقافة اسلامية } & \\
\hline $100.0 \%$ & $58 \%$ & $42 \%$ & النسبة \% & & \\
\hline 136 & $110 a$ & $26 a$ & التكرار & \multirow{2}{*}{ تربية خاصة } & \\
\hline $100.0 \%$ & $80.9 \%$ & $19.1 \%$ & النسبة \% & & \\
\hline 16 & $12 a$ & $4 \mathbf{a}$ & التكرار & \multirow{2}{*}{ فنية } & \\
\hline $100.0 \%$ & $75.0 \%$ & $25.0 \%$ & النسبة \% & & \\
\hline 518 & 399 & 119 & التكرار & \multirow{2}{*}{\multicolumn{2}{|c|}{ المجموع }} \\
\hline $100.0 \%$ & $77.0 \%$ & $23.0 \%$ & النسبة \% & & \\
\hline \multicolumn{3}{|c|}{$10.642 a$} & \multicolumn{3}{|c|}{ قيمة اختبار كاY } \\
\hline
\end{tabular}

جدول (ب ا ) نتائج اختبار مربع كاي لالالة الفروق بين التكرارات والنسب المئوية للاستجابات على فقرات البعد الرابع

\begin{tabular}{|c|c|c|c|c|c|}
\hline \multirow{2}{*}{ المجموع } & \multicolumn{2}{|c|}{ q69 } & & \multirow{4}{*}{ علم نفس } & \\
\hline & & غي مولفة & & & \multirow{11}{*}{ 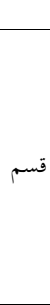 } \\
\hline 220 & $199 a$ & $21 a$ & التكرار & & \\
\hline $100.0 \%$ & $90.5 \%$ & $9.5 \%$ & النسبة \% & & \\
\hline 138 & $125 a$ & $13 a$ & التكرار & \multirow{2}{*}{ رياض أطفال } & \\
\hline $100.0 \%$ & $90.6 \%$ & $9.4 \%$ & النسبة \% & & \\
\hline 8 & 7 & 5 & التكرار & \multirow{2}{*}{ ثقافة اسلامية } & \\
\hline $100.0 \%$ & $58 \%$ & $42 \%$ & النسبة \% & & \\
\hline 136 & $125 a$ & $11 a$ & التكرار & \multirow{2}{*}{ تربية خاصة } & \\
\hline $100.0 \%$ & $91.9 \%$ & $8.1 \%$ & النسبة \% & & \\
\hline 16 & $16 a$ & $0 a$ & التكرار & \multirow{2}{*}{ فنية } & \\
\hline $100.0 \%$ & $100.0 \%$ & $0.0 \%$ & النسبة \% & & \\
\hline 518 & 470 & 48 & التكرار & \multirow{2}{*}{\multicolumn{2}{|c|}{ المجموع }} \\
\hline $100.0 \%$ & $90.7 \%$ & $9.3 \%$ & النسبة \% & & \\
\hline \multicolumn{3}{|c|}{$9.468 \mathrm{a}$} & \multicolumn{3}{|c|}{ قيمة اختبار مربع كاى } \\
\hline \multirow{2}{*}{ المجموع } & \multicolumn{2}{|c|}{ Q70 } & & \multirow{2}{*}{ فيمه (ختبار م } & \\
\hline & موافق & غير موافق & & & \\
\hline 220 & $196 b$ & $24 a$ & التكرار & \multirow{2}{*}{ علم نفس } & \multirow{10}{*}{ قسم } \\
\hline $100.0 \%$ & $89.1 \%$ & $10.9 \%$ & النسبة \% & & \\
\hline 138 & $133 b$ & $5 \mathbf{a}$ & التكرار & \multirow{2}{*}{ رياض أطفال } & \\
\hline $100.0 \%$ & $96.4 \%$ & $3.6 \%$ & النسبة \% & & \\
\hline 8 & 7 & 5 & التكرار & \multirow{2}{*}{ ثقافة اسلامية } & \\
\hline $100.0 \%$ & $58 \%$ & $42 \%$ & النسبة \% & & \\
\hline 136 & 128a & $8 \mathbf{a}$ & التكرار & \multirow{2}{*}{ تربية خاصة } & \\
\hline $100.0 \%$ & $94.1 \%$ & $5.9 \%$ & النسبة \% & & \\
\hline 16 & $15 a$ & $1 a$ & التكرار & \multirow{2}{*}{ فنية } & \\
\hline $100.0 \%$ & $93.8 \%$ & $6.3 \%$ & النسبة \% & & \\
\hline 518 & 477 & 41 & التكا. & \multirow{3}{*}{\multicolumn{2}{|c|}{ قيمة اختبار مر }} \\
\hline $1000 \%$ & $92.1 \%$ & $79 \%$ & 1لنسة & & \\
\hline \multicolumn{3}{|c|}{$16.632 * *$} & كاي & & \\
\hline
\end{tabular}

جلول (ء 1) نتائج اختبار مريع كاي لدلالة الفروق التكرارات والنسب النئوية (بين الأقتام)

للموافقة على فقرات البعد الخامس من المقياس لاسل

\begin{tabular}{|c|c|c|c|c|c|}
\hline \multirow{2}{*}{ المجموع } & \multicolumn{2}{|l|}{ a78 } & & & \multirow{8}{*}{ قسم } \\
\hline & موافقت & غير موافق & & \multirow[b]{2}{*}{ علم } & \\
\hline 220 & $181 a$ & 39a & التكرارات & & \\
\hline $100.0 \%$ & $82.3 \%$ & $17.7 \%$ & النسبة \% & نفيس & \\
\hline 138 & $123 a$ & $15 a$ & التكرارات & رياض & \\
\hline $100.0 \%$ & $89.1 \%$ & $10.9 \%$ & النسبة \% & أطفالر & \\
\hline 8 & 6 & 6 & التكرارات & ثقافة & \\
\hline $100.0 \%$ & $50.0 \%$ & $50.0 \%$ & النسبة \% & لسيلامية & \\
\hline 136 & $117 a$ & 19a & التكرارات & تربية & \\
\hline $100.0 \%$ & $86.0 \%$ & $14.0 \%$ & النسبة \% & خاصة & \\
\hline 16 & $15 a$ & $1 \mathrm{a}$ & التكرارات & فنية & \\
\hline $100.0 \%$ & $93.8 \%$ & $6.3 \%$ & النسبة \% & نيكي & \\
\hline 518 & 440 & 78 & التكرايرات & & \\
\hline $100.0 \%$ & $84.9 \%$ & $15.1 \%$ & النسبة \% & & \\
\hline
\end{tabular}


جدول (10) قيمة ودلالة اختبار مريع كاي لفروق تكرارات الموافقة (بين المستويات الدراسية) على مضامين بنود مقياس

\begin{tabular}{|c|c|c|c|c|c|}
\hline \multicolumn{6}{|c|}{ الاراسة } \\
\hline \multirow{2}{*}{ المجموع } & & q3 & & & \\
\hline & موافت & غيز موافق & & & \\
\hline 1147 & $09 \mathrm{~b}$ & $\vee \vee_{a}$ & التكرار & \multirow{2}{*}{ الأول حتى الرابع } & \multirow{4}{*}{ مستوى } \\
\hline$\%$ Y. 1 & $\% Y \cdot . \Lambda$ & \% rY.s & \% النسبة \% & & \\
\hline พ^ฯ & rYob & $171 \mathrm{a}$ & التكرار & \multirow{2}{*}{ الخامس حتى الثامث: } & \\
\hline$\% \vee Y .9$ & $\% \vee q . Y$ & $\% 7 \vee .7$ & \% النسبة & & \\
\hline OYY & $r \wedge \leq$ & 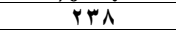 & التكرار & \multirow{2}{*}{\multicolumn{2}{|c|}{ المجموع }} \\
\hline$\% 1 \ldots$ & $\% 1 \ldots$ & $\% 1 \ldots$ & \% النسبة & & \\
\hline \multicolumn{3}{|c|}{$* * 9.1$} & \multicolumn{3}{|c|}{ قيمة مربع كاى } \\
\hline \multirow{2}{*}{ المجموع } & \multicolumn{2}{|c|}{ q12 } & & & \\
\hline & موافق & غير موافق & & & \\
\hline 1147 & $\wedge \vee \mathbf{b}$ & $\leqslant 9 a$ & التكرار & & \multirow{4}{*}{ مستوى } \\
\hline$\%$ \% & $\%$ Yr.. & $\% \% \wedge .7$ & \% النسبة & الاول & \\
\hline พА & $\vec{r} \cdot \hat{\mathbf{b}}$ & $\vee \wedge \mathbf{a}$ & التكرار & الخ الخ & \\
\hline$\% \vee r .9$ & $\% \vee \wedge$. & $\% 71.5$ & \% النسبة & & \\
\hline OYY & 190 & IYV & التكرار & & \\
\hline$\%$ & $\%$ & $\% 1 \ldots$ & \% النسبةة & جموع & \\
\hline & $* * 1 \% . \cdot V$ & & & مربع ك & \\
\hline & & 26 & & & \\
\hline المجموع & موافت & غير موافت & & & \\
\hline 1147 & $90 \mathbf{b}$ & $\leqslant 1 a$ & التكرار & & \\
\hline$\%$ \%. 1 & $\%$ Y.$\wedge$ & $\% r \cdot . r$ & \% النسبة \% & الاول & \\
\hline พᄉ & $r \quad \leq \leq \mathbf{b}$ & $17 \mathrm{ra}$ & التكرار & الخ الخ & مستوى \\
\hline$\% \vee r . q$ & $\% \vee \cdot . r$ & $\% \vee 9 . \wedge$ & \% النسبة \% & & \\
\hline OYY & 119 & $r \cdot r$ & التكرار & & \\
\hline$\%$ & $\%$ & $\%$ & \% النسبة & جموع & \\
\hline & $* 0.9$ & & & مربع S & \\
\hline & & 27 & & & \\
\hline المجموع & موافتي & غير موافقي & & & \\
\hline $1 \mathrm{Hy}$ & $1 \leq b$ & Irra & التكرار & 21 & \\
\hline$\%$ \% & 010.9 & $\%$ \% . 1 & \% النسبة & رابع & مبت \\
\hline พАY & $V \leq \mathbf{b}$ & rira & التكرار & الخا & مستوى \\
\hline$\% \vee r .9$ & $\% \wedge \varepsilon .1$ & $\% \vee 1.9$ & \% النسبة & & \\
\hline OYY & $\wedge \wedge$ & $\varepsilon \Psi \varepsilon$ & التكرار & & \\
\hline$\% 1 \ldots$ & $\% 1 \ldots$ & $\% 1 \ldots$ & \% النسبة \% & جموع & \\
\hline & $* 0 . V$ & & & قيمة مربع ك & \\
\hline المحمو ع & & q31 & & & \\
\hline المجموع & موافق & غيز موافق & & & \\
\hline 1147 & ${ }_{b}^{\wedge Y}$ & $a^{0} \leq$ & التكرار & & \\
\hline$\%$ \% 1.1 & $\%$ Y & $\% \mu \wedge . r$ & \% النسبة & الاو & \\
\hline $\mathrm{r \wedge t}$ & $b^{Y 99}$ & $a^{\wedge \vee V}$ & التكرار . & الخـــــام & مسسوى \\
\hline$\% \vee r .9$ & $\% \vee \wedge .0$ & $\% 71 . \mathrm{V}$ & \% النسبة: & الثامن: & \\
\hline OYY & $M \wedge I$ & $1 \leqslant 1$ & التكرار & & \\
\hline$\% 1 \ldots$ & $\% 1 \ldots$ & $\% 1 \ldots$ & \% النسبة & & المجموع \\
\hline & 20 & $* 10$ & & & قيمة مربع \\
\hline can all & & q41 & & & \\
\hline المجموع & موافق & غيز موافق & & & \\
\hline $1 \% 9$ & $h^{Y r}$ & a $11 \leq$ & التكرار & & \\
\hline$\%$ \% 1.1 & $\% 19$. & $\%$ \%^. 1 & \% النسبة & الاول حا & \\
\hline rAT & $b^{9} \leq$ & a rqr & التكرار & الخــــامس & مسسوى \\
\hline$\%$ VY.q & $\% \wedge 1$. & $\% \vee 1.9$ & \% النسبة & الثامن: & \\
\hline OrY & 117 & $\varepsilon .7$ & التكرار 'י & & \\
\hline$\% 1 \ldots$ & $\% 1 \ldots$ & $\% 1 \cdots$ & \% النسبة & & المجموع \\
\hline & . & $* 4.9$ & & & قيمة مربع \\
\hline & & a44 & & & \\
\hline المجموع & موافق & غير موافق & & & \\
\hline $1 \mathrm{HY}$ & $n^{71}$ & $a^{7 \Lambda}$ & التكرار . & & \\
\hline$\%$ r $\% .1$ & \% rr.V & $\%$ & \% النسبة & لرابع & \\
\hline$r \wedge \eta$ & $h^{Y M T}$ & $a^{100}$ & التكرار & الخـــــامس حتــــي & مسنوى \\
\hline$\% \vee r .9$ & $\% \vee \vee . r$ & $\% 79.0$ & \% النسبة & الثامن: & \\
\hline OYY & $r 99$ & TrY & التكرار & & \\
\hline$\% 1 \ldots$ & $\%$ & $\% 1 \ldots$ & \% \% النسبة & & المجموع \\
\hline & & $* \varepsilon$ & & & قيمة مربع \\
\hline المحمد ع & q59 & & & & \\
\hline المجموع & موافق & غير موافث & & & \\
\hline 136 & $79_{h}$ & $57_{\mathrm{a}}$ & التكرار & & \\
\hline $26.1 \%$ & $30.2 \%$ & $21.9 \%$ & النسبة \% & الاول حنى الرابع & ميتت 6 \\
\hline 386 & $183_{b}$ & $203_{a}$ & التكرار & الخـــــامس حتــــي & مسنوى \\
\hline $73.9 \%$ & $69.8 \%$ & $78.1 \%$ & النسبة \% & الثامن & \\
\hline 522 & 262 & 260 & التكرار & & المجموع \\
\hline
\end{tabular}




\begin{tabular}{|c|c|c|c|c|c|}
\hline$\frac{100.0 \%}{\xi 7^{*}}$ & $100.0 \%$ & $100.0 \%$ & النسبة \% & \multicolumn{2}{|r|}{ مريع كاي } \\
\hline Total & \multicolumn{2}{|l|}{ a90 } & & & \\
\hline 136 & مو $88_{\mathrm{h}}$ & غيز مواقق ، 48 & الت ال & & \multirow{3}{*}{ مستوى } \\
\hline $26.1 \%$ & $23.2 \%$ & $33.6 \%$ & النسبة \% & الاول & \\
\hline $\begin{array}{l}386 \\
73.9\end{array}$ & $291_{h}$ & $95_{\mathrm{a}}$ & التكرار & الثاني & \\
\hline 522 & $\begin{array}{l}379 \% \\
379\end{array}$ & $\begin{array}{l}0.4 \% \\
143\end{array}$ & التكرار & & المجموع \\
\hline $\begin{array}{l}100.0 \% \\
5.8^{\star}\end{array}$ & $100.0 \%$ & $100.0 \%$ & & & مربع كاي \\
\hline
\end{tabular}

جدول (1 () قيمة ودلالة اختبار مريع كاي للفروق بين تكرارات الموافقة (بين الأفراد مختلفي المعل التراكمي)

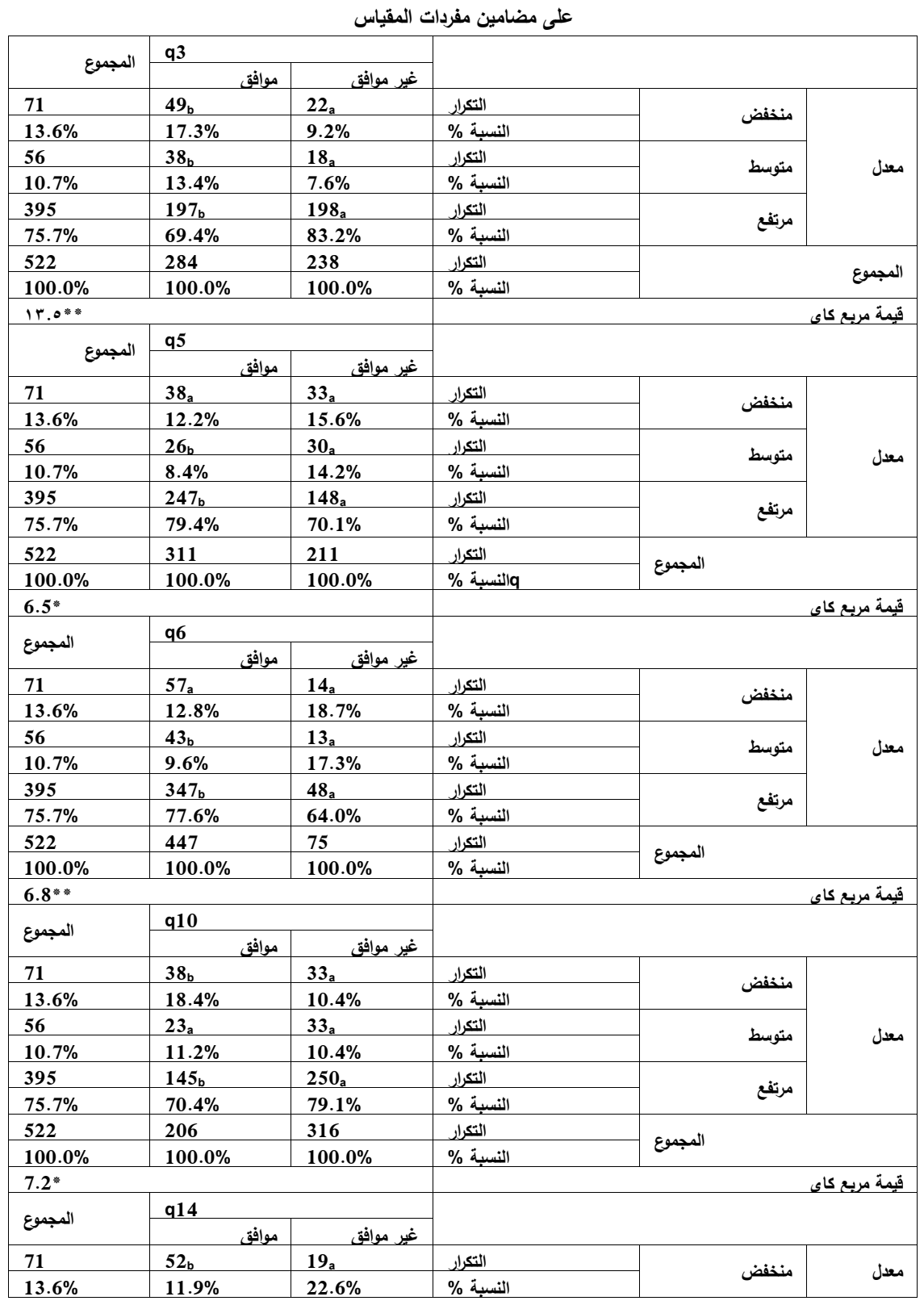




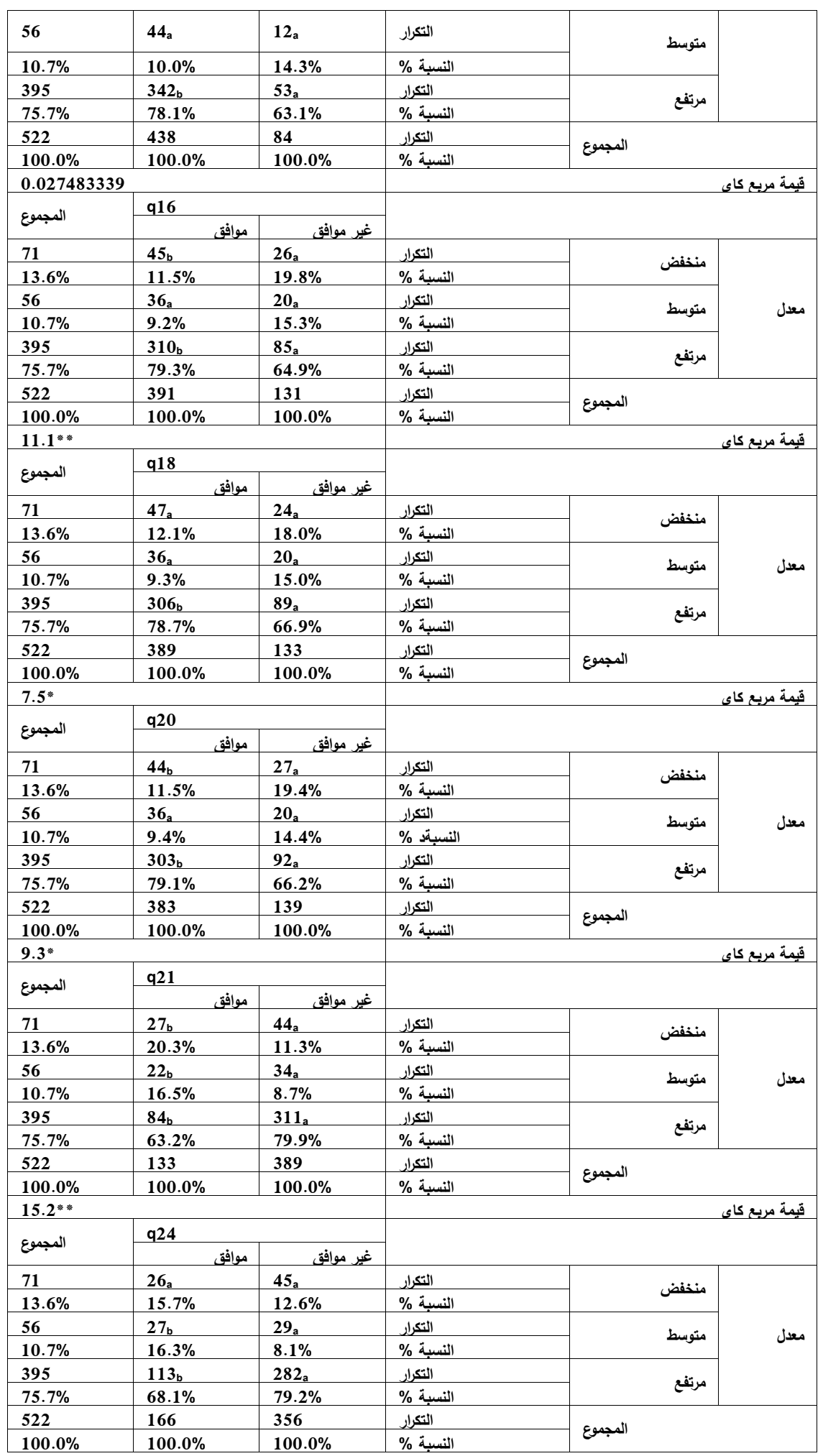




\begin{tabular}{|c|c|c|c|c|c|}
\hline \multicolumn{3}{|l|}{9.6 ** } & & & \multirow[t]{3}{*}{ قيمة مريع كاى } \\
\hline \multirow{2}{*}{ المجموع } & \multicolumn{2}{|l|}{$q 26$} & & & \\
\hline & موافق & غير موافق & & & \\
\hline 71 & $33_{b}$ & $38_{a}$ & التكرار & \multirow{2}{*}{ منخفض } & \multirow{6}{*}{ 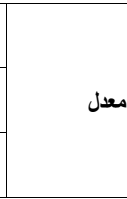 } \\
\hline $13.6 \%$ & $10.3 \%$ & $18.7 \%$ & النسبة \% & & \\
\hline 56 & $30_{a}$ & $26_{a}$ & التكرار & \multirow{2}{*}{ متوسط } & \\
\hline $10.7 \%$ & $9.4 \%$ & $12.8 \%$ & النسبة \% & & \\
\hline 395 & $256_{b}$ & $139 a_{a}$ & التكرار & \multirow{2}{*}{ مرتفع } & \\
\hline $75.7 \%$ & $80.3 \%$ & $68.5 \%$ & النسبة \% & & \\
\hline 522 & 319 & 203 & التكرار & \multirow{2}{*}{ المجموع } & \multirow[b]{3}{*}{ قيمة مربع كاى } \\
\hline $100.0 \%$ & $100.0 \%$ & $100.0 \%$ & النسبة \% & & \\
\hline \multicolumn{3}{|l|}{$10^{\text {*** }}$} & & & \\
\hline \multirow{2}{*}{ المجموع } & \multicolumn{2}{|l|}{$\mathbf{q 2 7}$} & & & \multirow{8}{*}{ معدل } \\
\hline & موافق & غير موافق & & & \\
\hline 71 & $17_{a}$ & $54 a$ & التكرار & \multirow{2}{*}{ منخفض } & \\
\hline $13.6 \%$ & $19.3 \%$ & $12.4 \%$ & النسبة \% & & \\
\hline 56 & $15_{b}$ & $41_{a}$ & التكرار & متوسط & \\
\hline $10.7 \%$ & $17.0 \%$ & $9.4 \%$ & النسبة \% & متوست & \\
\hline 395 & $56_{b}$ & $339 a_{a}$ & التكرار & مرتفع & \\
\hline $75.7 \%$ & $63.6 \%$ & $78.1 \%$ & النسبة \% & مرتع & \\
\hline 522 & 88 & 434 & التكرار & المحموع & \\
\hline $100.0 \%$ & $100.0 \%$ & $100.0 \%$ & النسبة \% & יד & \\
\hline $8.5 * *$ & & & & & قيمة مربع كاي \\
\hline المجموع & $q 28$ & & & & \\
\hline & موافق & غير موافق & & & \\
\hline 71 & $43_{a}$ & $28_{a}$ & التكرار & منذفضض & \\
\hline $13.6 \%$ & $12.8 \%$ & $15.1 \%$ & النسبة \% & 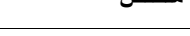 & \\
\hline 56 & $28_{b}$ & $28 \mathrm{a}$ & التكرار & متوسط & معدل \\
\hline $10.7 \%$ & $8.3 \%$ & $15.1 \%$ & النسبة \% & متونس & \\
\hline 395 & $265_{b}$ & $130_{a}$ & التكرار & مرتفع & \\
\hline $75.7 \%$ & $78.9 \%$ & $69.9 \%$ & النسبة \% & مرتع & \\
\hline 522 & 336 & 186 & التكرار & المحموع & \\
\hline $100.0 \%$ & $100.0 \%$ & $100.0 \%$ & النسبة \% & اتسبوح & \\
\hline $6.8 *$ & & & & & قيمة مربع كاى \\
\hline المجموع & $q 29$ & & & & \\
\hline & موافق & غير موافق & & & \\
\hline 71 & $38_{b}$ & $33_{a}$ & التكرار & منخفض & \\
\hline $13.6 \%$ & $11.3 \%$ & $17.7 \%$ & النسبة \% & & \\
\hline 56 & $32 \mathrm{a}$ & $24_{a}$ & التكرار & تته سط & معال \\
\hline $10.7 \%$ & $9.5 \%$ & $12.9 \%$ & النسبة \% & متوبند & مغدر \\
\hline 395 & $266_{b}$ & $129 a$ & التكرار & مرتفع & \\
\hline $75.7 \%$ & $79.2 \%$ & $69.4 \%$ & النسبة \% & مرتع & \\
\hline 522 & 336 & 186 & التكرار & المحموع & \\
\hline $100.0 \%$ & $100.0 \%$ & $100.0 \%$ & النسبة \% & اتمجموح & \\
\hline $6.4 *$ & & & & & قيمة مربع كاى \\
\hline المحموع & $q 30$ & & & & \\
\hline اسبطوح & موافق & غير موافق & & & \\
\hline 71 & $53_{b}$ & $18 \mathrm{a}$ & التكرار & ضض & \\
\hline $13.6 \%$ & $12.0 \%$ & $22.2 \%$ & النسبة \% & & \\
\hline 56 & $42_{b}$ & $14 a$ & التكرار & متوسط & معدل \\
\hline $10.7 \%$ & $9.5 \%$ & $17.3 \%$ & النسبة \% & & مغ فل \\
\hline 395 & $346_{b}$ & $49 \mathrm{a}$ & التكرار & مرتفع & \\
\hline $75.7 \%$ & $78.5 \%$ & $60.5 \%$ & النسبة \% & ئرحت & \\
\hline 522 & 441 & 81 & التكرار & المحهوع & \\
\hline $100.0 \%$ & $100.0 \%$ & $100.0 \%$ & النسبة \% & المجموع & \\
\hline $12^{* * *}$ & & & & & قيمة مربع كاى \\
\hline المجموع & $q 33$ & & & & \\
\hline & موافق & غير موافق & & & \\
\hline 71 & $48_{a}$ & $\mathbf{2 3}_{\mathrm{a}}$ & التكرار & منخفض & \\
\hline $13.6 \%$ & $14.8 \%$ & $11.7 \%$ & النسبة \% & & معدل \\
\hline 56 & $42_{b}$ & $14 a$ & ل التكرار & متوسط & ה \\
\hline $10.7 \%$ & $12.9 \%$ & $7.1 \%$ & النسبة \% & ملتونس & \\
\hline
\end{tabular}

$\varepsilon \Gamma$. 
المجلد الخامس والعشرون (العدد الرايع) لسنة ه 10

مجلة كلية التربية ـ جامعة الإسكندرية

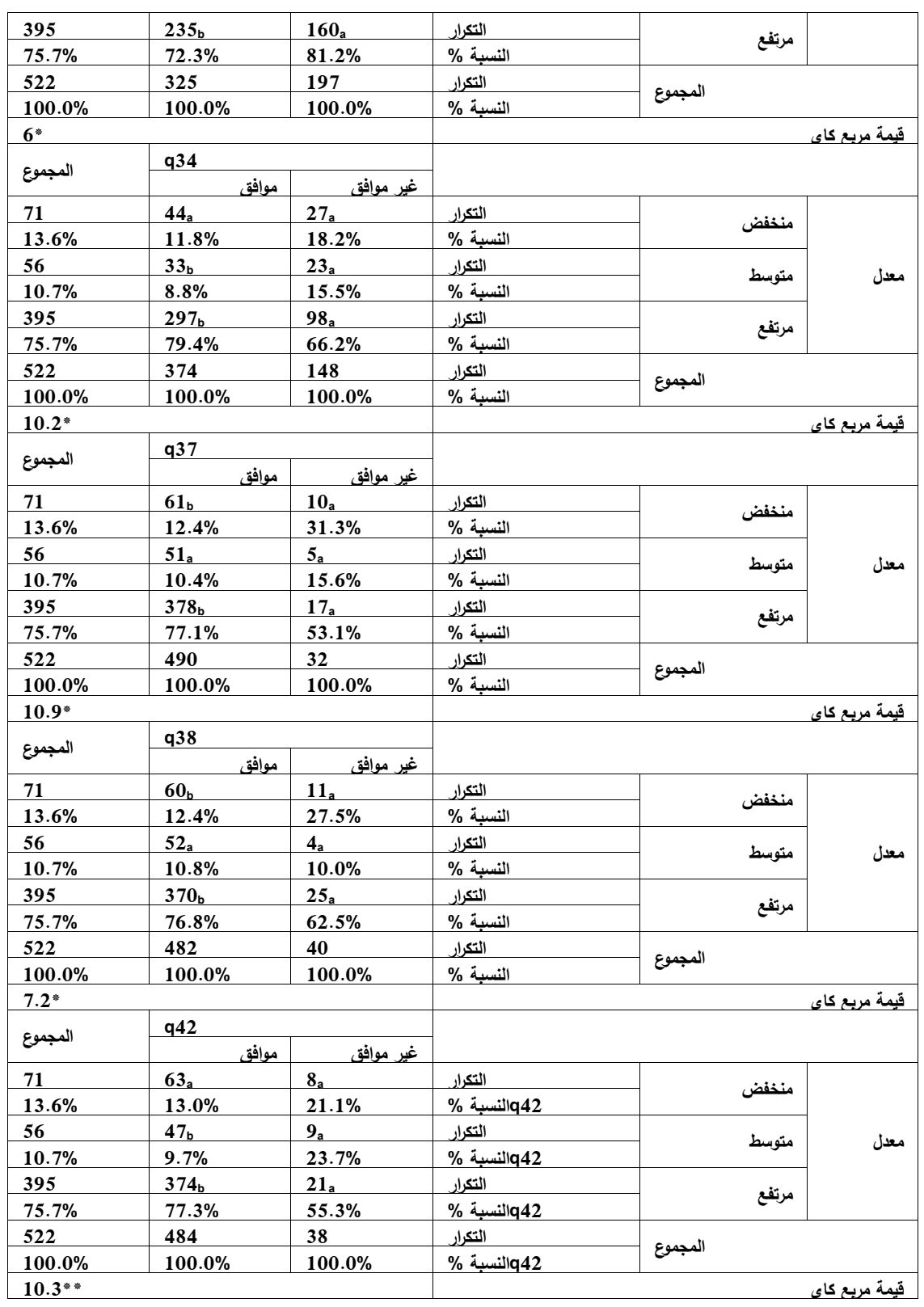




\section{ملخص الدراسة}

هدفت هذه الدراسة إلى الكثف عن أساليب التقويم التي تستخدم

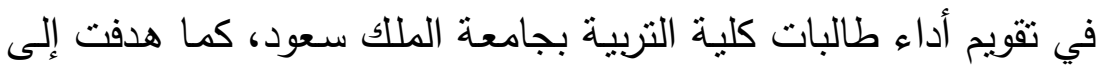
التعرف على اتجاهات الطالبات نحو أساليب التقويم المستخدمة في تقويم أدائهن وكذلك الكثف عما إذا كانت هناك فروق بين اتجاهات الطالبات نحو أسـاليب التقويم التي تسـتخدم في تقويمهن وفقـا لـنظم الاعتمـاد الأكاديمي تبعا لاختلاف التخصص والمستوى الدراسي والمعدل الدراسي

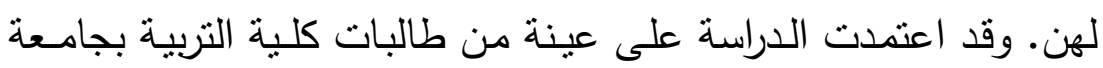
الملك سعود اختيرت بطريقة عشوائية من جميع الاقسام، وقد بلغ حجم

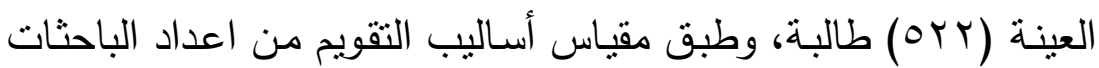
على أفراد العينة. وقد أظهرت نتائج الدراســة إلى وجـود اختلاف بـين طالبـات الأقسـام

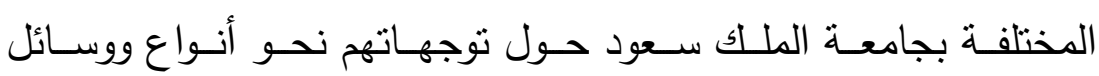
وإجراءات ومراحل التقويم، وقد بدا من النتائج أنه توجد اتجاهات إيجابية

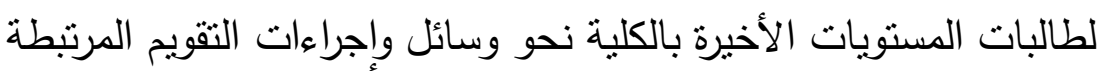

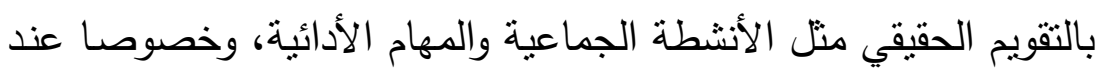

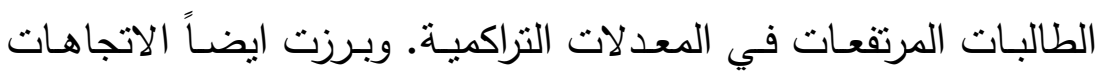

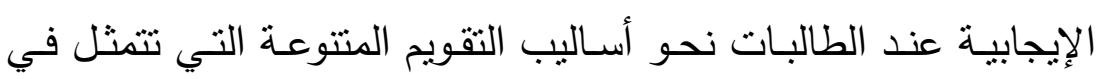
استخدام أنواع مختلفة من الاختبارات ووسائل ومراحل التقويم التي تغطي كل جوانب العملية التعلمية. 


\begin{abstract}
This study aims to reveal the methods of evaluation used in evaluating the performance of girl students at college of Education at King Saud University. The study also aims to identify students' attitudes towards the evaluation methods used to evaluate their performance, as well as to detect whether there are differences between the attitudes of students towards evaluation methods used in accreditation systems depending on different specialization, academic level, and average of Academy rate. The study sample consisted of (522 girls students) from college of Education selected from all departments. The instrument of data collection was a questionnaire, which prepared by the authors. Results showed differences between the students of different departments at the college of Education on their attitudes toward the types and methods, procedures and stages of evaluation. In addition, the results showed positive attitude appered spcilicty at higher average cumlutive grade students. Furthemore, the results showed positive attitudes toward the various evalution methods that include use different types of tests, means and stages evaluation that cover all aspects of the learning process.
\end{abstract}

